\title{
Voltage-gated potassium channels (version 2019.4) in the IUPHAR/BPS Guide to Pharmacology Database
}

\author{
Bernard Attali ${ }^{1}$, K. George Chandy ${ }^{2}$, M. Hunter Giese ${ }^{3}$, Stephan Grissmer ${ }^{4}$, George A. Gutman², Lily Y. Jan ${ }^{5}$, \\ Michel Lazdunski ${ }^{6}$, David Mckinnon ${ }^{7}$, Jeanne Nerbonne ${ }^{8}$, Luis A. Pardo ${ }^{9}$, Gail A. Robertson ${ }^{10}$, Bernardo \\ Rudy ${ }^{11}$, Michael C. Sanguinetti ${ }^{12}$, Walter Stühmer ${ }^{9}$, James S. Trimmer ${ }^{13}$ and Xiaoliang Wang ${ }^{14}$ \\ 1. Tel Aviv University, Israel \\ 2. University of California Irvine, USA \\ 3. Columbia University, USA \\ 4. Ulm University, Germany \\ 5. University of California San Francisco, USA \\ 6. CNRS Valbonne, France \\ 7. State University of New York at Stony Brook, USA \\ 8. Washington University, USA \\ 9. Max Planck Institute for Experimental Medicine, Germany \\ 10. University of Wisconsin-Madison, USA \\ 11. New York University, USA \\ 12. University of Utah, USA \\ 13. University of California Davis, USA \\ 14. Peking Union Medical College, China
}

\begin{abstract}
The 6TM family of $\mathrm{K}$ channels comprises the voltage-gated $\mathrm{K}_{\mathrm{V}}$ subfamilies, the EAG subfamily (which includes hERG channels), the $\mathrm{Ca}^{2+}$-activated Slo subfamily (actually with 7TM, termed BK) and the Cä ${ }^{++}$-activated SK subfamily. These channels possess a pore-forming $\alpha$ subunit that comprise tetramers of identical subunits (homomeric) or of different subunits (heteromeric). Heteromeric channels can only be formed within subfamilies (e.g. $\mathrm{K}_{\mathrm{v}} 1.1$ with $\mathrm{K}_{\mathrm{v}} 1.2 ; \mathrm{K}_{\mathrm{v}} 7.2$ with $\mathrm{K}_{\mathrm{v}} 7.3$ ). The pharmacology largely reflects the subunit composition of the functional channel.
\end{abstract}

\section{Contents}

This is a citation summary for Voltage-gated potassium channels in the Guide to Pharmacology database (GtoPdb). It exists purely as an adjunct to the database to facilitate the recognition of citations to and from the database by citation analyzers. Readers will almost certainly want to visit the relevant sections of the database which are given here under database links.

GtoPdb is an expert-driven guide to pharmacological targets and the substances that act on them. GtoPdb is a reference work which is most usefully represented as an on-line database. As in any publication this work should be appropriately cited, and the papers it cites should also be recognized. This document provides a citation for the relevant parts of the database, and also provides a reference list for the research cited by those 
parts.

Please note that the database version for the citations given in GtoPdb are to the most recent preceding version in which the family or its subfamilies and targets were substantially changed. The links below are to the current version. If you need to consult the cited version, rather than the most recent version, please contact the GtoPdb curators.

\section{Database links}

Voltage-gated potassium channels

http://www.guidetopharmacology.org/GRAC/FamilyDisplayForward?familyld=81

Introduction to Voltage-gated potassium channels

http://www.guidetopharmacology.org/GRAC/FamilyIntroductionForward?familyld=81

Channels and Subunits

$\mathrm{K}_{\mathrm{v}} 1.1$

http://www.guidetopharmacology.org/GRAC/ObjectDisplayForward?objectld=538

$\mathrm{K}_{\mathrm{v}} 1.2$

http://www.guidetopharmacology.org/GRAC/ObjectDisplayForward?objectld=539

$\mathrm{K}_{\mathrm{v}} 1.3$

http://www.guidetopharmacology.org/GRAC/ObjectDisplayForward?objectld=540

$\mathrm{K}_{\mathrm{v}} 1.4$

http://www.guidetopharmacology.org/GRAC/ObjectDisplayForward?objectld=541

$\mathrm{K}_{\mathrm{v}} 1.5$

http://www.guidetopharmacology.org/GRAC/ObjectDisplayForward?objectld=542

$\mathrm{K}_{\mathrm{v}} 1.6$

http://www.guidetopharmacology.org/GRAC/ObjectDisplayForward?objectld=543

$\mathrm{K}_{\mathrm{v}} 1.7$

http://www.guidetopharmacology.org/GRAC/ObjectDisplayForward?objectld=544

$\mathrm{K}_{\mathrm{v}} 1.8$

http://www.guidetopharmacology.org/GRAC/ObjectDisplayForward?objectld=545

$\mathrm{K}_{\mathrm{v}} 2.1$

http://www.guidetopharmacology.org/GRAC/ObjectDisplayForward?objectld=546

$\mathrm{K}_{\mathrm{v}} 2.2$

http://www.guidetopharmacology.org/GRAC/ObjectDisplayForward?objectld=547

$\mathrm{K}_{\mathrm{v}} 3.1$

http://www.guidetopharmacology.org/GRAC/ObjectDisplayForward?objectld=548

$\mathrm{K}_{\mathrm{v}} 3.2$

http://www.guidetopharmacology.org/GRAC/ObjectDisplayForward?objectld=549

$\mathrm{K}_{\mathrm{v}} 3.3$

http://www.guidetopharmacology.org/GRAC/ObjectDisplayForward?objectld=550

$\mathrm{K}_{\mathrm{v}} 3.4$

http://www.guidetopharmacology.org/GRAC/ObjectDisplayForward?objectld=551

$\mathrm{K}_{\mathrm{v}} 4.1$

http://www.guidetopharmacology.org/GRAC/ObjectDisplayForward?objectld=552

$\mathrm{K}_{\mathrm{v}} 4.2$

http://www.guidetopharmacology.org/GRAC/ObjectDisplayForward?objectld=553

$\mathrm{K}_{\mathrm{v}} 4.3$

http://www.guidetopharmacology.org/GRAC/ObjectDisplayForward?objectld=554

$\mathrm{K}_{\mathrm{v}} 5.1$ 
http://www.guidetopharmacology.org/GRAC/ObjectDisplayForward?objectld=555

$\mathrm{K}_{\mathrm{v}} 6.1$

http://www.guidetopharmacology.org/GRAC/ObjectDisplayForward?objectld=556

$\mathrm{K}_{\mathrm{v}} 6.2$

http://www.guidetopharmacology.org/GRAC/ObjectDisplayForward?objectld=557

$\mathrm{K}_{\mathrm{v}} 6.3$

http://www.guidetopharmacology.org/GRAC/ObjectDisplayForward?objectld=558

$\mathrm{K}_{\mathrm{v}} 6.4$

http://www.guidetopharmacology.org/GRAC/ObjectDisplayForward?objectld=559

$\mathrm{K}_{\mathrm{v}} 7.1$

http://www.guidetopharmacology.org/GRAC/ObjectDisplayForward?objectld=560

$\mathrm{K}_{\mathrm{v}} 7.2$

http://www.guidetopharmacology.org/GRAC/ObjectDisplayForward?objectld=561

$\mathrm{K}_{\mathrm{v}} 7.3$

http://www.guidetopharmacology.org/GRAC/ObjectDisplayForward?objectld=562

$\mathrm{K}_{\mathrm{v}} 7.4$

http://www.guidetopharmacology.org/GRAC/ObjectDisplayForward?objectld=563

$\mathrm{K}_{\mathrm{v}} 7.5$

http://www.guidetopharmacology.org/GRAC/ObjectDisplayForward?objectld=564

$\mathrm{K}_{\mathrm{v}} 8.1$

http://www.guidetopharmacology.org/GRAC/ObjectDisplayForward?objectld=565

$\mathrm{K}_{\mathrm{v}} 8.2$

http://www.guidetopharmacology.org/GRAC/ObjectDisplayForward?objectld=566

$\mathrm{K}_{\mathrm{v}} 9.1$

http://www.guidetopharmacology.org/GRAC/ObjectDisplayForward?objectld=567

$\mathrm{K}_{\mathrm{v}} 9.2$

http://www.guidetopharmacology.org/GRAC/ObjectDisplayForward?objectld=568

$\mathrm{K}_{\mathrm{v}} 9.3$

http://www.guidetopharmacology.org/GRAC/ObjectDisplayForward?objectld=569

$\mathrm{K}_{\mathrm{v}} 10.1$

http://www.guidetopharmacology.org/GRAC/ObjectDisplayForward?objectld=570

$\mathrm{K}_{\mathrm{v}} 10.2$

http://www.guidetopharmacology.org/GRAC/ObjectDisplayForward?objectld=571

$\mathrm{K}_{\mathrm{V}} 11.1$

http://www.guidetopharmacology.org/GRAC/ObjectDisplayForward?objectld=572

$\mathrm{K}_{\mathrm{v}} 11.2$

http://www.guidetopharmacology.org/GRAC/ObjectDisplayForward?objectld=573

$\mathrm{K}_{\mathrm{v}} 11.3$

http://www.guidetopharmacology.org/GRAC/ObjectDisplayForward?objectld=574

$\mathrm{K}_{\mathrm{v}} 12.1$

http://www.guidetopharmacology.org/GRAC/ObjectDisplayForward?objectld=575

$\mathrm{K}_{\mathrm{v}} 12.2$

http://www.guidetopharmacology.org/GRAC/ObjectDisplayForward?objectld=576

$\mathrm{K}_{\mathrm{v}} 12.3$

http://www.guidetopharmacology.org/GRAC/ObjectDisplayForward?objectld=577

\section{References}


1. A-González $N$ and Castrillo $A$. (2011) Liver $X$ receptors as regulators of macrophage inflammatory and metabolic pathways. Biochim. Biophys. Acta 1812: 982-94 [PMID:21193033]

2. Abbott GW, Butler MH, Bendahhou S, Dalakas MC, Ptacek LJ and Goldstein SA. (2001) MiRP2 forms potassium channels in skeletal muscle with Kv3.4 and is associated with periodic paralysis. Cell 104: 21731 [PMID:11207363]

3. Abbott GW, Butler MH and Goldstein SA. (2006) Phosphorylation and protonation of neighboring MiRP2 sites: function and pathophysiology of MiRP2-Kv3.4 potassium channels in periodic paralysis. FASEB J. 20: 293-301 [PMID:16449802]

4. Abbott GW, Sesti F, Splawski I, Buck ME, Lehmann MH, Timothy KW, Keating MT and Goldstein SA. (1999) MiRP1 forms IKr potassium channels with HERG and is associated with cardiac arrhythmia. Cell 97: 175-87 [PMID:10219239]

5. Adams JP, Anderson AE, Varga AW, Dineley KT, Cook RG, Pfaffinger PJ and Sweatt JD. (2000) The Atype potassium channel Kv4.2 is a substrate for the mitogen-activated protein kinase ERK. J. Neurochem. 75: 2277-87 [PMID:11080179]

6. Adelman JP, Bond CT, Pessia M and Maylie J. (1995) Episodic ataxia results from voltage-dependent potassium channels with altered functions. Neuron 15: 1449-54 [PMID:8845167]

7. Ahn HS, Kim SE, Jang HJ, Kim MJ, Rhie DJ, Yoon SH, Jo YH, Kim MS, Sung KW and Hahn SJ. (2006) Interaction of riluzole with the closed inactivated state of Kv4.3 channels. J. Pharmacol. Exp. Ther. 319: 323-31 [PMID:16815868]

8. Akemann W and Knöpfel T. (2006) Interaction of Kv3 potassium channels and resurgent sodium current influences the rate of spontaneous firing of Purkinje neurons. J. Neurosci. 26: 4602-12 [PMID:16641240]

9. Al-Sabi A, Shamotienko O, Dhochartaigh SN, Muniyappa N, Le Berre M, Shaban H, Wang J, Sack JT and Dolly JO. (2010) Arrangement of Kv1 alpha subunits dictates sensitivity to tetraethylammonium. J. Gen. Physiol. 136: 273-82 [PMID:20805574]

10. Albrecht B, Lorra C, Stocker M and Pongs O. (1993) Cloning and characterization of a human delayed rectifier potassium channel gene. Recept. Channels 1: 99-110 [PMID:8081723]

11. Albrecht B, Weber K and Pongs O. (1995) Characterization of a voltage-activated K-channel gene cluster on human chromosome 12p13. Recept. Channels 3: 213-20 [PMID:8821794]

12. Ambriz-Rivas M, Islas LD and Gomez-Lagunas F. (2005) K+-dependent stability and ion conduction of Shab K+ channels: a comparison with Shaker channels. Pflugers Arch. 450: 255-61 [PMID:15909181]

13. An WF, Bowlby MR, Betty M, Cao J, Ling HP, Mendoza G, Hinson JW, Mattsson KI, Strassle BW and Trimmer JS et al.. (2000) Modulation of A-type potassium channels by a family of calcium sensors Nature 403: 553-6 [PMID:10676964]

14. Anderson CL, Delisle BP, Anson BD, Kilby JA, Will ML, Tester DJ, Gong Q, Zhou Z, Ackerman MJ and January CT. (2006) Most LQT2 mutations reduce Kv11.1 (hERG) current by a class 2 (trafficking-deficient) mechanism. Circulation 113: 365-73 [PMID:16432067]

15. Anderson ME. (2005) Calmodulin kinase signaling in heart: an intriguing candidate target for therapy of myocardial dysfunction and arrhythmias. Pharmacol. Ther. 106: 39-55 [PMID:15781121]

16. Angelo K, Jespersen T, Grunnet M, Nielsen MS, Klaerke DA and Olesen SP. (2002) KCNE5 induces timeand voltage-dependent modulation of the KCNQ1 current. Biophys. J. 83: 1997-2006 [PMID:12324418]

17. Apud JA, Zhang F, Decot H, Bigos KL and Weinberger DR. (2012) Genetic variation in KCNH2 associated with expression in the brain of a unique hERG isoform modulates treatment response in patients with schizophrenia. Am J Psychiatry 169: 725-34 [PMID:22706279]

18. Arcangeli A. (2005) Expression and role of hERG channels in cancer cells.Novartis Found. Symp. 266: 225-32; discussion 232-4 [PMID:16050271]

19. Arcangeli A, Rosati B, Cherubini A, Crociani O, Fontana L, Ziller C, Wanke E and Olivotto M. (1997) HERG- and IRK-like inward rectifier currents are sequentially expressed during neuronal development of neural crest cells and their derivatives. Eur. J. Neurosci. 9: 2596-604 [PMID:9517465]

20. Archer SL, Souil E, Dinh-Xuan AT, Schremmer B, Mercier JC, El Yaagoubi A, Nguyen-Huu L, Reeve HL and Hampl V. (1998) Molecular identification of the role of voltage-gated K+ channels, Kv1.5 and Kv2.1, in 
hypoxic pulmonary vasoconstriction and control of resting membrane potential in rat pulmonary artery myocytes. J. Clin. Invest. 101: 2319-30 [PMID:9616203]

21. Arkett SA, Dixon J, Yang JN, Sakai DD, Minkin C and Sims SM. (1994) Mammalian osteoclasts express a transient potassium channel with properties of Kv1.3. Recept. Channels 2: 281-93 [PMID:7536610]

22. Attali B, Romey G, Honoré E, Schmid-Alliana A, Mattéi MG, Lesage F, Ricard P, Barhanin J and Lazdunski M. (1992) Cloning, functional expression, and regulation of two $\mathrm{K}+$ channels in human $\mathrm{T}$ lymphocytes. J. Biol. Chem. 267: 8650-7 [PMID:1373731]

23. Attali B, Wang N, Kolot A, Sobko A, Cherepanov V and Soliven B. (1997) Characterization of delayed rectifier Kv channels in oligodendrocytes and progenitor cells. J. Neurosci. 17: 8234-45 [PMID:9334399]

24. Aydar E, Palmer CP, Klyachko VA and Jackson MB. (2002) The sigma receptor as a ligand-regulated auxiliary potassium channel subunit. Neuron 34: 399-410 [PMID:11988171]

25. Bachmann A, Gutcher I, Kopp K, Brendel J, Bosch RF, Busch AE and Gögelein H. (2001) Characterization of a novel Kv1.5 channel blocker in Xenopus oocytes, $\mathrm{CHO}$ cells, human and rat cardiomyocytes. Naunyn Schmiedebergs Arch. Pharmacol. 364: 472-8 [PMID:11692231]

26. Bahl A, Barton P, Bowers K, Brough S, Evans R, Luckhurst CA, Mochel T, Perry MW, Rigby A and Riley RJ et al.. (2012) The discovery of CCR3/H1 dual antagonists with reduced hERG risk.Bioorg. Med. Chem. Lett. 22: 6688-93 [PMID:23031591]

27. Bal M, Zhang J, Zaika O, Hernandez CC and Shapiro MS. (2008) Homomeric and heteromeric assembly of KCNQ (Kv7) K+ channels assayed by total internal reflection fluorescence/fluorescence resonance energy transfer and patch clamp analysis. J. Biol. Chem. 283: 30668-76 [PMID:18786918]

28. Banfi S, Borsani G, Rossi E, Bernard L, Guffanti A, Rubboli F, Marchitiello A, Giglio S, Coluccia E, Zollo M, Zuffardi $O$ and Ballabio A. (1996) Identification and mapping of human cDNAs homologous to Drosophila mutant genes through EST database searching. Nat. Genet. 13: 167-74 [PMID:8640222]

29. Baranauskas G, Tkatch T and Surmeier DJ. (1999) Delayed rectifier currents in rat globus pallidus neurons are attributable to Kv2.1 and Kv3.1/3.2 K(+) channels. J. Neurosci. 19: 6394-404 [PMID:10414968]

30. Bardien-Kruger S, Wulff $H$, Arieff $Z$, Brink $P$, Chandy KG and Corfield V. (2002) Characterisation of the human voltage-gated potassium channel gene, KCNA7, a candidate gene for inherited cardiac disorders, and its exclusion as cause of progressive familial heart block I (PFHBI). Eur. J. Hum. Genet. 10: 36-43 [PMID:11896454]

31. Barhanin J, Lesage F, Guillemare E, Fink M, Lazdunski M and Romey G. (1996) K(V)LQT1 and IsK (minK) proteins associate to form the I(Ks) cardiac potassium current. Nature 384: 78-80 [PMID:8900282]

32. Barro-Soria R, Rebolledo S, Liin SI, Perez ME, Sampson KJ, Kass RS and Larsson HP. (2014) KCNE1 divides the voltage sensor movement in KCNQ1/KCNE1 channels into two steps. Nat Commun 5: 3750 [PMID:24769622]

33. Barry DM, Trimmer JS, Merlie JP and Nerbonne JM. (1995) Differential expression of voltage-gated K+ channel subunits in adult rat heart. Relation to functional K+ channels? Circ. Res. 77: 361-9 [PMID:7614722]

34. Barry DM, Xu H, Schuessler RB and Nerbonne JM. (1998) Functional knockout of the transient outward current, long-QT syndrome, and cardiac remodeling in mice expressing a dominant-negative Kv4 alpha subunit. Circ. Res. 83: 560-7 [PMID:9734479]

35. Bartok A, Toth A, Somodi S, Szanto TG, Hajdu P, Panyi G and Varga Z. (2014) Margatoxin is a nonselective inhibitor of human Kv1.3 K+ channels. Toxicon 87: 6-16 [PMID:24878374]

36. Becchetti A, De Fusco M, Crociani O, Cherubini A, Restano-Cassulini R, Lecchi M, Masi A, Arcangeli A, Casari $G$ and Wanke E. (2002) The functional properties of the human ether-à-go-go-like (HELK2) K+ channel. Eur. J. Neurosci. 16: 415-28 [PMID:12193184]

37. Beck EJ, Bowlby M, An WF, Rhodes KJ and Covarrubias M. (2002) Remodelling inactivation gating of Kv4 channels by KChIP1, a small-molecular-weight calcium-binding protein. J. Physiol. (Lond.) 538: 691-706 [PMID:11826158]

38. Beck EJ and Covarrubias M. (2001) Kv4 channels exhibit modulation of closed-state inactivation in insideout patches. Biophys. J. 81: 867-83 [PMID:11463631] 
39. Beckh S and Pongs O. (1990) Members of the RCK potassium channel family are differentially expressed in the rat nervous system. EMBO J. 9: 777-82 [PMID:2311579]

40. Beeton C, Barbaria J, Giraud P, Devaux J, Benoliel AM, Gola M, Sabatier JM, Bernard D, Crest M and Béraud E. (2001) Selective blocking of voltage-gated K+ channels improves experimental autoimmune encephalomyelitis and inhibits T cell activation. J. Immunol. 166: 936-44 [PMID:11145670]

41. Beeton C, Pennington MW, Wulff H, Singh S, Nugent D, Crossley G, Khaytin I, Calabresi PA, Chen CY, Gutman GA and Chandy KG. (2005) Targeting effector memory T cells with a selective peptide inhibitor of Kv1.3 channels for therapy of autoimmune diseases. Mol. Pharmacol. 67: 1369-81 [PMID:15665253]

42. Beeton $\mathrm{C}$, Wulff $\mathrm{H}$, Barbaria J, Clot-Faybesse $\mathrm{O}$, Pennington $\mathrm{M}$, Bernard $\mathrm{D}$, Cahalan MD, Chandy KG and Béraud E. (2001) Selective blockade of T lymphocyte $\mathrm{K}(+)$ channels ameliorates experimental autoimmune encephalomyelitis, a model for multiple sclerosis. Proc. Natl. Acad. Sci. U.S.A. 98: 13942-7 [PMID:11717451]

43. Beeton $\mathrm{C}$, Wulff $\mathrm{H}$, Standifer NE, Azam P, Mullen KM, Pennington MW, Kolski-Andreaco A, Wei E, Grino A, Counts DR, Wang PH, LeeHealey CJ, S Andrews B, Sankaranarayanan A, Homerick D, Roeck WW, Tehranzadeh J, Stanhope KL, Zimin P, Havel PJ, Griffey S, Knaus HG, Nepom GT, Gutman GA, Calabresi PA and Chandy KG. (2006) Kv1.3 channels are a therapeutic target for T cell-mediated autoimmune diseases. Proc. Natl. Acad. Sci. U.S.A. 103: 17414-9 [PMID:17088564]

44. Beisel KW, Rocha-Sanchez SM, Morris KA, Nie L, Feng F, Kachar B, Yamoah EN and Fritzsch B. (2005) Differential expression of KCNQ4 in inner hair cells and sensory neurons is the basis of progressive highfrequency hearing loss. J. Neurosci. 25: 9285-93 [PMID:16207888]

45. Bekele-Arcuri Z, Matos MF, Manganas L, Strassle BW, Monaghan MM, Rhodes KJ and Trimmer JS. (1996) Generation and characterization of subtype-specific monoclonal antibodies to K+ channel alphaand beta-subunit polypeptides. Neuropharmacology 35: 851-65 [PMID:8938716]

46. Bellocq C, van Ginneken AC, Bezzina CR, Alders M, Escande D, Mannens MM, Baró I and Wilde AA. (2004) Mutation in the KCNQ1 gene leading to the short QT-interval syndrome. Circulation 109: 2394-7 [PMID:15159330]

47. Bentzen BH, Schmitt N, Calloe K, Dalby Brown W, Grunnet M and Olesen SP. (2006) The acrylamide (S)1 differentially affects Kv7 (KCNQ) potassium channels. Neuropharmacology 51: 1068-77 [PMID:16904708]

48. Biervert C, Schroeder BC, Kubisch C, Berkovic SF, Propping P, Jentsch TJ and Steinlein OK. (1998) A potassium channel mutation in neonatal human epilepsy. Science 279: 403-6 [PMID:9430594]

49. Biju KC, Marks DR, Mast TG and Fadool DA. (2008) Deletion of voltage-gated channel affects glomerular refinement and odorant receptor expression in the mouse olfactory system. J. Comp. Neurol. 506: 161-79 [PMID:18022950]

50. Bildl W, Haupt A, Müller CS, Biniossek ML, Thumfart JO, Hüber B, Fakler B and Schulte U. (2012) Extending the dynamic range of label-free mass spectrometric quantification of affinity purifications. Mol. Cell Proteomics 11: M111.007955 [PMID:22067099]

51. Bilet A and Bauer CK. (2012) Effects of the small molecule HERG activator NS1643 on Kv11.3 channels. PLOS ONE 7: e50886 [PMID:23226420]

52. Blaine JT and Ribera AB. (1998) Heteromultimeric potassium channels formed by members of the Kv2 subfamily. J. Neurosci. 18: 9585-93 [PMID:9822719]

53. Blaine JT, Taylor AD and Ribera AB. (2004) Carboxyl tail region of the Kv2.2 subunit mediates novel developmental regulation of channel density. J. Neurophysiol. 92: 3446-54 [PMID:15306626]

54. Blair TA, Roberds SL, Tamkun MM and Hartshorne RP. (1991) Functional characterization of RK5, a voltage-gated $\mathrm{K}+$ channel cloned from the rat cardiovascular system. FEBS Lett. 295: 211-3 [PMID:1722463]

55. Bocksteins E, Labro AJ, Snyders DJ and Mohapatra DP. (2012) The electrically silent Kv6.4 subunit confers hyperpolarized gating charge movement in Kv2.1/Kv6.4 heterotetrameric channels. PLOS ONE 7: e37143 [PMID:22615922]

56. Bocksteins E, Mayeur E, Van Tilborg A, Regnier G, Timmermans JP and Snyders DJ. (2014) The 
subfamily-specific interaction between Kv2.1 and Kv6.4 subunits is determined by interactions between the $\mathrm{N}$ - and C-termini. PLoS ONE 9: e98960 [PMID:24901643]

57. Boczek NJ, Ye D, Johnson EK, Wang W, Crotti L, Tester DJ, Dagradi F, Mizusawa Y, Torchio M and Alders $M$ et al.. (2014) Characterization of SEMA3A-encoded semaphorin as a naturally occurring Kv4.3 protein inhibitor and its contribution to Brugada syndrome. Circ. Res. 115: 460-9 [PMID:24963029]

58. Bracey K, Ju M, Tian C, Stevens $L$ and Wray D. (2008) Tubulin as a binding partner of the heag2 voltagegated potassium channel. J. Membr. Biol. 222: 115-25 [PMID:18458804]

59. Brahmajothi MV, Morales MJ, Liu S, Rasmusson RL, Campbell DL and Strauss HC. (1996) In situ hybridization reveals extensive diversity of $\mathrm{K}+$ channel mRNA in isolated ferret cardiac myocytes. Circ. Res. 78: 1083-9 [PMID:8635239]

60. Brew HM, Gittelman JX, Silverstein RS, Hanks TD, Demas VP, Robinson LC, Robbins CA, McKeeJohnson J, Chiu SY and Messing A et al.. (2007) Seizures and reduced life span in mice lacking the potassium channel subunit Kv1.2, but hypoexcitability and enlarged Kv1 currents in auditory neurons. J. Neurophysiol. 98: 1501-25 [PMID:17634333]

61. Brooke RE, Atkinson L, Edwards I, Parson SH and Deuchars J. (2006) Immunohistochemical localisation of the voltage gated potassium ion channel subunit Kv3.3 in the rat medulla oblongata and thoracic spinal cord. Brain Res. 1070: 101-15 [PMID:16403474]

62. Brooke RE, Corns L, Edwards IJ and Deuchars J. (2010) Kv3.3 immunoreactivity in the vestibular nuclear complex of the rat with focus on the medial vestibular nucleus: targeting of Kv3.3 neurones by terminals positive for vesicular glutamate transporter 1. Brain Res. 1345: 45-58 [PMID:20471378]

63. Browne DL, Gancher ST, Nutt JG, Brunt ER, Smith EA, Kramer P and Litt M. (1994) Episodic ataxia/myokymia syndrome is associated with point mutations in the human potassium channel gene, KCNA1. Nat. Genet. 8: 136-40 [PMID:7842011]

64. Brueggemann LI, Mackie AR, Cribbs LL, Freda J, Tripathi A, Majetschak M and Byron KL. (2014) Differential protein kinase C-dependent modulation of Kv7.4 and Kv7.5 subunits of vascular Kv7 channels. J. Biol. Chem. 289: 2099-111 [PMID:24297175]

65. Brueggemann LI, Moran CJ, Barakat JA, Yeh JZ, Cribbs LL and Byron KL. (2007) Vasopressin stimulates action potential firing by protein kinase C-dependent inhibition of KCNQ5 in A7r5 rat aortic smooth muscle cells. Am. J. Physiol. Heart Circ. Physiol. 292: H1352-63 [PMID:17071736]

66. Brugada R, Hong K, Dumaine R, Cordeiro J, Gaita F, Borggrefe M, Menendez TM, Brugada J, Pollevick GD and Wolpert $C$ et al.. (2004) Sudden death associated with short-QT syndrome linked to mutations in HERG. Circulation 109: 30-5 [PMID:14676148]

67. Brundel BJ, Van Gelder IC, Henning RH, Tuinenburg AE, Wietses M, Grandjean JG, Wilde AA, Van Gilst WH and Crijns HJ. (2001) Alterations in potassium channel gene expression in atria of patients with persistent and paroxysmal atrial fibrillation: differential regulation of protein and mRNA levels for $\mathrm{K}+$ channels. J. Am. Coll. Cardiol. 37: 926-32 [PMID:11693772]

68. Brüggemann A, Pardo LA, Stühmer W and Pongs O. (1993) Ether-à-go-go encodes a voltage-gated channel permeable to $\mathrm{K}+$ and $\mathrm{Ca} 2+$ and modulated by cAMP. Nature 365: 445-8 [PMID:7692301]

69. Brüggemann A, Stühmer W and Pardo LA. (1997) Mitosis-promoting factor-mediated suppression of a cloned delayed rectifier potassium channel expressed in Xenopus oocytes. Proc. Natl. Acad. Sci. U.S.A. 94: 537-42 [PMID:9012819]

70. Busch AE, Busch GL, Ford E, Suessbrich H, Lang HJ, Greger R, Kunzelmann K, Attali B and Stühmer W. (1997) The role of the IsK protein in the specific pharmacological properties of the IKs channel complex. Br. J. Pharmacol. 122: 187-9 [PMID:9313924]

71. Busch AE, Herzer T, Wagner CA, Schmidt F, Raber G, Waldegger S and Lang F. (1994) Positive regulation by chloride channel blockers of IsK channels expressed in Xenopus oocytes. Mol. Pharmacol. 46: 750-3 [PMID:7969055]

72. Bähring R, Boland LM, Varghese A, Gebauer M and Pongs O. (2001) Kinetic analysis of open- and closedstate inactivation transitions in human Kv4.2 A-type potassium channels. J. Physiol. (Lond.) 535: 65-81 [PMID:11507158] 
73. Caballero R, Pourrier M, Schram G, Delpón E, Tamargo J and Nattel S. (2003) Effects of flecainide and quinidine on Kv4.2 currents: voltage dependence and role of S6 valines. Br. J. Pharmacol. 138: 1475-84 [PMID:12721103]

74. Cachero TG, Morielli AD and Peralta EG. (1998) The small GTP-binding protein RhoA regulates a delayed rectifier potassium channel. Cell 93: 1077-85 [PMID:9635436]

75. Cahalan MD, Chandy KG, DeCoursey TE and Gupta S. (1985) A voltage-gated potassium channel in human T lymphocytes. J. Physiol. (Lond.) 358: 197-237 [PMID:2580081]

76. Camacho J, Sánchez A, Stühmer W and Pardo LA. (2000) Cytoskeletal interactions determine the electrophysiological properties of human EAG potassium channels. Pflugers Arch. 441: 167-74 [PMID:11211100]

77. Carlisle FA, Steel KP and Lewis MA. (2012) Specific expression of Kcna10, Pxn and Odf2 in the organ of Corti. Gene Expr. Patterns 12: 172-9 [PMID:22446089]

78. Carninci P, Kasukawa T, Katayama S, Gough J, Frith MC, Maeda N, Oyama R, Ravasi T, Lenhard B and Wells $C$ et al.. (2005) The transcriptional landscape of the mammalian genome.Science 309: 1559-63 [PMID:16141072]

79. Carrasquillo Y, Burkhalter A and Nerbonne JM. (2012) A-type K+ channels encoded by Kv4.2, Kv4.3 and Kv1.4 differentially regulate intrinsic excitability of cortical pyramidal neurons. J. Physiol. (Lond.) 590: 387790 [PMID:22615428]

80. Casis O, Olesen SP and Sanguinetti MC. (2006) Mechanism of action of a novel human ether-a-go-gorelated gene channel activator. Mol. Pharmacol. 69: 658-65 [PMID:16284303]

81. Castellano A, Chiara MD, Mellström B, Molina A, Monje F, Naranjo JR and López-Barneo J. (1997) Identification and functional characterization of a $\mathrm{K}+$ channel alpha-subunit with regulatory properties specific to brain. J. Neurosci. 17: 4652-61 [PMID:9169526]

82. Chadha PS, Zunke F, Davis AJ, Jepps TA, Linders JT, Schwake M, Towart R and Greenwood IA. (2012) Pharmacological dissection of $\mathrm{K}(\mathrm{v}) 7.1$ channels in systemic and pulmonary arteries. Br. J. Pharmacol. 166: 1377-87 [PMID:22251082]

83. Chagot B, Escoubas P, Villegas E, Bernard C, Ferrat G, Corzo G, Lazdunski M and Darbon H. (2004) Solution structure of Phrixotoxin 1, a specific peptide inhibitor of Kv4 potassium channels from the venom of the theraphosid spider Phrixotrichus auratus. Protein Sci. 13: 1197-208 [PMID:15096626]

84. Chandy KG Wulff H Beeton C Calabresi P Gutman GA Pennington M. (2006) Kv1.3 Potassium Channel: Physiology, Pharmacology and Therapeutic Indications. In Voltage-gated lon Channels as Drug Targets Edited by Triggle, D: WILEY-VCH Weinheim: 214-272 [ISBN: 3-527-31258-7]

85. Chandy KG, Williams CB, Spencer RH, Aguilar BA, Ghanshani S, Tempel BL and Gutman GA. (1990) A family of three mouse potassium channel genes with intronless coding regions. Science 247: 973-5 [PMID:2305265]

86. Chandy KG, Wulff H, Beeton C, Pennington M, Gutman GA and Cahalan MD. (2004) K+ channels as targets for specific immunomodulation. Trends Pharmacol. Sci. 25: 280-9 [PMID:15120495]

87. Chang SY, Zagha E, Kwon ES, Ozaita A, Bobik M, Martone ME, Ellisman MH, Heintz N and Rudy B. (2007) Distribution of Kv3.3 potassium channel subunits in distinct neuronal populations of mouse brain. J. Comp. Neurol. 502: 953-72 [PMID:17444489]

88. Charlier C, Singh NA, Ryan SG, Lewis TB, Reus BE, Leach RJ and Leppert M. (1998) A pore mutation in a novel KQT-like potassium channel gene in an idiopathic epilepsy family. Nat. Genet. 18: 53-5 [PMID:9425900]

89. Chen H, von Hehn C, Kaczmarek LK, Ment LR, Pober BR and Hisama FM. (2007) Functional analysis of a novel potassium channel (KCNA1) mutation in hereditary myokymia. Neurogenetics 8: 131-5 [PMID:17136396]

90. Chen L, Kurokawa J and Kass RS. (2005) Phosphorylation of the A-kinase-anchoring protein Yotiao contributes to protein kinase A regulation of a heart potassium channel. J. Biol. Chem. 280: 31347-52 [PMID:16002409]

91. Chen M, Li J, Zhang F and Liu Z. (2014) Isolation and characterization of SsmTx-I, a Specific Kv2.1 
blocker from the venom of the centipede Scolopendra Subspinipes Mutilans L. Koch. J. Pept. Sci. 20: 15964 [PMID:24464516]

92. Chen YH, Xu SJ, Bendahhou S, Wang XL, Wang Y, Xu WY, Jin HW, Sun H, Su XY and Zhuang QNet al.. (2003) KCNQ1 gain-of-function mutation in familial atrial fibrillation. Science 299: 251-4 [PMID:12522251]

93. Chiara MD, Monje F, Castellano A and López-Barneo J. (1999) A small domain in the $\mathrm{N}$ terminus of the regulatory alpha-subunit Kv2. 3 modulates Kv2.1 potassium channel gating. J. Neurosci. 19: 6865-73 [PMID:10436044]

94. Chittajallu R, Chen Y, Wang H, Yuan X, Ghiani CA, Heckman T, McBain CJ and Gallo V. (2002) Regulation of Kv1 subunit expression in oligodendrocyte progenitor cells and their role in $\mathrm{G} 1 / \mathrm{S}$ phase progression of the cell cycle. Proc. Natl. Acad. Sci. U.S.A. 99: 2350-5 [PMID:11854528]

95. Choi BH, Choi JS, Yoon SH, Rhie DJ, Min DS, Jo YH, Kim MS and Hahn SJ. (2001) Effects of norfluoxetine, the major metabolite of fluoxetine, on the cloned neuronal potassium channel Kv3.1. Neuropharmacology 41: 443-53 [PMID:11543764]

96. Choi SH, Shin TJ, Hwang SH, Lee BH, Kang J, Kim HJ, Jo SH, Choe H and Nah SY. (2011) Ginsenoside $\mathrm{Rg}(3)$ decelerates hERG K(+) channel deactivation through Ser631 residue interaction. Eur. J. Pharmacol. 663: 59-67 [PMID:21586280]

97. Chow A, Erisir A, Farb C, Nadal MS, Ozaita A, Lau D, Welker E and Rudy B. (1999) K(+) channel expression distinguishes subpopulations of parvalbumin- and somatostatin-containing neocortical interneurons. J. Neurosci. 19: 9332-45 [PMID:10531438]

98. Christophersen IE, Olesen MS, Liang B, Andersen MN, Larsen AP, Nielsen JB, Haunsø S, Olesen SP, Tveit A and Svendsen JH et al.. (2013) Genetic variation in KCNA5: impact on the atrial-specific potassium current IKur in patients with lone atrial fibrillation. Eur. Heart J. 34: 1517-25 [PMID:23264583]

99. Christopoulos A, Changeux JP, Catterall WA, Fabbro D, Burris TP, Cidlowski JA, Olsen RW, Peters JA, Neubig RR and Pin JP et al.. (2014) International union of basic and clinical pharmacology. XC. multisite pharmacology: recommendations for the nomenclature of receptor allosterism and allosteric ligands. Pharmacol. Rev. 66: 918-47 [PMID:25026896]

100. Cicek MS, Koestler DC, Fridley BL, Kalli KR, Armasu SM, Larson MC, Wang C, Winham SJ, Vierkant RA and Rider DN et al.. (2013) Epigenome-wide ovarian cancer analysis identifies a methylation profile differentiating clear-cell histology with epigenetic silencing of the HERG K+ channel. Hum. Mol. Genet. 22: 3038-47 [PMID:23571109]

101. Clancy SM, Chen B, Bertaso F, Mamet J and Jegla T. (2009) KCNE1 and KCNE3 beta-subunits regulate membrane surface expression of $\mathrm{Kv} 12.2 \mathrm{~K}(+)$ channels in vitro and form a tripartite complex in vivo. PLoS ONE 4: e6330 [PMID:19623261]

102. Coghlan MJ, Carroll WA and Gopalakrishnan M. (2001) Recent developments in the biology and medicinal chemistry of potassium channel modulators: update from a decade of progress. J. Med. Chem. 44: 162753 [PMID:11356099]

103. Coleman SK, Newcombe J, Pryke J and Dolly JO. (1999) Subunit composition of Kv1 channels in human CNS. J. Neurochem. 73: 849-58 [PMID:10428084]

104. Colinas O, Gallego M, Setién R, López-López JR, Pérez-García MT and Casis O. (2006) Differential modulation of Kv4.2 and Kv4.3 channels by calmodulin-dependent protein kinase II in rat cardiac myocytes. Am. J. Physiol. Heart Circ. Physiol. 291: H1978-87 [PMID:16648177]

105. Cooper EC, Aldape KD, Abosch A, Barbaro NM, Berger MS, Peacock WS, Jan YN and Jan LY. (2000) Colocalization and coassembly of two human brain M-type potassium channel subunits that are mutated in epilepsy. Proc. Natl. Acad. Sci. U.S.A. 97: 4914-9 [PMID:10781098]

106. Cooper EC, Harrington E, Jan YN and Jan LY. (2001) M channel KCNQ2 subunits are localized to key sites for control of neuronal network oscillations and synchronization in mouse brain. J. Neurosci. 21: 952940 [PMID:11739564]

107. Cotton J, Crest M, Bouet F, Alessandri N, Gola M, Forest E, Karlsson E, Castañeda O, Harvey AL and Vita C et al.. (1997) A potassium-channel toxin from the sea anemone Bunodosoma granulifera, an inhibitor for Kv1 channels. Revision of the amino acid sequence, disulfide-bridge assignment, chemical synthesis, and 
biological activity. Eur. J. Biochem. 244: 192-202 [PMID:9063464]

108. Coucke PJ, Van Hauwe P, Kelley PM, Kunst H, Schatteman I, Van Velzen D, Meyers J, Ensink RJ, Verstreken M and Declau F et al.. (1999) Mutations in the KCNQ4 gene are responsible for autosomal dominant deafness in four DFNA2 families. Hum. Mol. Genet. 8: 1321-8 [PMID:10369879]

109. Cukovic D, Lu GW, Wible B, Steele DF and Fedida D. (2001) A discrete amino terminal domain of Kv1.5 and Kv1.4 potassium channels interacts with the spectrin repeats of alpha-actinin-2. FEBS Lett. 498: 87-92 [PMID:11389904]

110. Curran ME, Landes GM and Keating MT. (1992) Molecular cloning, characterization, and genomic localization of a human potassium channel gene. Genomics 12: 729-37 [PMID:1349297]

111. Curran ME, Splawski I, Timothy KW, Vincent GM, Green ED and Keating MT. (1995) A molecular basis for cardiac arrhythmia: HERG mutations cause long QT syndrome. Cell 80: 795-803 [PMID:7889573]

112. Czirják G, Tóth ZE and Enyedi P. (2007) Characterization of the heteromeric potassium channel formed by kv2.1 and the retinal subunit kv8.2 in Xenopus oocytes. J. Neurophysiol. 98: 1213-22 [PMID:17652418]

113. Dallas ML, Atkinson L, Milligan CJ, Morris NP, Lewis DI, Deuchars SA and Deuchars J. (2005) Localization and function of the Kv3.1b subunit in the rat medulla oblongata: focus on the nucleus tractus solitarii. J. Physiol. (Lond.) 562: 655-72 [PMID:15528247]

114. Davies AR and Kozlowski RZ. (2001) Kv channel subunit expression in rat pulmonary arteries.Lung 179: 147-61 [PMID:11891605]

115. De Biasi M, Drewe JA, Kirsch GE and Brown AM. (1993) Histidine substitution identifies a surface position and confers Cs+ selectivity on a K+ pore. Biophys. J. 65: 1235-42 [PMID:8241404]

116. DeCoursey TE, Chandy KG, Gupta S and Cahalan MD. (1984) Voltage-gated K+ channels in human T lymphocytes: a role in mitogenesis? Nature 307: 465-8 [PMID:6320007]

117. Dedek K, Kunath B, Kananura C, Reuner U, Jentsch TJ and Steinlein OK. (2001) Myokymia and neonatal epilepsy caused by a mutation in the voltage sensor of the KCNQ2 K+ channel. Proc. Natl. Acad. Sci. U.S.A. 98: 12272-7 [PMID:11572947]

118. Demolombe S, Franco D, de Boer P, Kuperschmidt S, Roden D, Pereon Y, Jarry A, Moorman AF and Escande D. (2001) Differential expression of KvLQT1 and its regulator IsK in mouse epithelia. Am. J. Physiol., Cell Physiol. 280: C359-72 [PMID:11208532]

119. Deschênes I and Tomaselli GF. (2002) Modulation of Kv4.3 current by accessory subunits.FEBS Lett. 528: 183-8 [PMID:12297301]

120. Deutsch C and Chen LQ. (1993) Heterologous expression of specific K+ channels in T lymphocytes: functional consequences for volume regulation. Proc. Natl. Acad. Sci. U.S.A. 90: 10036-40 [PMID:8234253]

121. Dilks D, Ling HP, Cockett M, Sokol P and Numann R. (1999) Cloning and expression of the human kv4.3 potassium channel. J. Neurophysiol. 81: 1974-7 [PMID:10200233]

122. Ding XW, Yan JJ, An P, Lü $P$ and Luo HS. (2007) Aberrant expression of ether à go-go potassium channel in colorectal cancer patients and cell lines. World J. Gastroenterol. 13: 1257-61 [PMID:17451210]

123. Diochot S, Drici MD, Moinier D, Fink M and Lazdunski M. (1999) Effects of phrixotoxins on the Kv4 family of potassium channels and implications for the role of Ito1 in cardiac electrogenesis. Br. J. Pharmacol. 126: 251-63 [PMID:10051143]

124. Diochot $S$, Loret $E$, Bruhn T, Béress $L$ and Lazdunski M. (2003) APETx1, a new toxin from the sea anemone Anthopleura elegantissima, blocks voltage-gated human ether-a-go-go-related gene potassium channels. Mol. Pharmacol. 64: 59-69 [PMID:12815161]

125. Diochot $S$, Schweitz H, Béress $L$ and Lazdunski M. (1998) Sea anemone peptides with a specific blocking activity against the fast inactivating potassium channel Kv3.4. J. Biol. Chem. 273: 6744-9 [PMID:9506974]

126. Dixon JE, Shi W, Wang HS, McDonald C, Yu H, Wymore RS, Cohen IS and McKinnon D. (1996) Role of the Kv4.3 K+ channel in ventricular muscle. A molecular correlate for the transient outward current. Circ. Res. 79: 659-68 [PMID:8831489]

127. Dodson PD, Barker MC and Forsythe ID. (2002) Two heteromeric Kv1 potassium channels differentially regulate action potential firing. J. Neurosci. 22: 6953-61 [PMID:12177193] 
128. Dong MQ, Lau CP, Gao Z, Tseng GN and Li GR. (2006) Characterization of recombinant human cardiac KCNQ1/KCNE1 channels (I (Ks)) stably expressed in HEK 293 cells. J. Membr. Biol. 210: 183-92 [PMID:16909339]

129. Douglass J, Osborne PB, Cai YC, Wilkinson M, Christie MJ and Adelman JP. (1990) Characterization and functional expression of a rat genomic DNA clone encoding a lymphocyte potassium channel. J. Immunol. 144: 4841-50 [PMID:2351830]

130. Down K, Amour A, Baldwin IR, Cooper AW, Deakin AM, Felton LM, Guntrip SB, Hardy C, Harrison ZA and Jones KL et al.. (2015) Optimization of Novel Indazoles as Highly Potent and Selective Inhibitors of Phosphoinositide 3-Kinase $\delta$ for the Treatment of Respiratory Disease. J. Med. Chem. 58: 7381-99 [PMID:26301626]

131. Downie BR, Sánchez A, Knötgen H, Contreras-Jurado C, Gymnopoulos M, Weber C, Stühmer W and Pardo LA. (2008) Eag1 expression interferes with hypoxia homeostasis and induces angiogenesis in tumors. J. Biol. Chem. 283: 36234-40 [PMID:18927085]

132. Drewe JA, Verma S, Frech $\mathrm{G}$ and Joho RH. (1992) Distinct spatial and temporal expression patterns of $\mathrm{K}_{+}$ channel mRNAs from different subfamilies. J. Neurosci. 12: 538-48 [PMID:1740690]

133. Duarri A, Jezierska J, Fokkens M, Meijer M, Schelhaas HJ, den Dunnen WF, van Dijk F, VerschuurenBemelmans $C$, Hageman $G$ and van de Vlies $P$ et al.. (2012) Mutations in potassium channel kcnd3 cause spinocerebellar ataxia type 19. Ann. Neurol. 72: 870-80 [PMID:23280838]

134. Duarri A, Nibbeling EA, Fokkens MR, Meijer M, Boerrigter M, Verschuuren-Bemelmans CC, Kremer BP, van de Warrenburg BP, Dooijes D and Boddeke E et al.. (2015) Functional analysis helps to define KCNC3 mutational spectrum in dutch ataxia cases. PLoS ONE 10: e0116599 [PMID:25756792]

135. Dudina EE, Korolkova YV, Bocharova NE, Koshelev SG, Egorov TA, Huys I, Tytgat J and Grishin EV. (2001) OsK2, a new selective inhibitor of Kv1.2 potassium channels purified from the venom of the scorpion Orthochirus scrobiculosus. Biochem. Biophys. Res. Commun. 286: 841-7 [PMID:11527374]

136. Dupuis DS, Schrøder RL, Jespersen T, Christensen JK, Christophersen P, Jensen BS and Olesen SP. (2002) Activation of KCNQ5 channels stably expressed in HEK293 cells by BMS-204352. Eur. J. Pharmacol. 437: 129-37 [PMID:11890900]

137. Ebbinghaus J, Legros C, Nolting A, Guette C, Celerier ML, Pongs $O$ and Bähring R. (2004) Modulation of $\mathrm{Kv} 4.2$ channels by a peptide isolated from the venom of the giant bird-eating tarantula Theraphosa leblondi. Toxicon 43: 923-32 [PMID:15208026]

138. Ebihara M, Ohba H, Kikuchi M and Yoshikawa T. (2004) Structural characterization and promoter analysis of human potassium channel Kv8.1 (KCNV1) gene. Gene 325: 89-96 [PMID:14697513]

139. Elmedyb P, Olesen SP and Grunnet M. (2007) Activation of ERG2 potassium channels by the diphenylurea NS1643. Neuropharmacology 53: 283-94 [PMID:17610913]

140. Engeland B, Neu A, Ludwig J, Roeper $J$ and Pongs O. (1998) Cloning and functional expression of rat ether-à-go-go-like K+ channel genes. J. Physiol. (Lond.) 513 ( Pt 3): 647-54 [PMID:9824707]

141. Erisir A, Lau D, Rudy B and Leonard CS. (1999) Function of specific K(+) channels in sustained highfrequency firing of fast-spiking neocortical interneurons. J. Neurophysiol. 82: 2476-89 [PMID:10561420]

142. Escoubas $P$, Diochot $S$, Célérier ML, Nakajima T and Lazdunski M. (2002) Novel tarantula toxins for subtypes of voltage-dependent potassium channels in the Kv2 and Kv4 subfamilies. Mol. Pharmacol. 62: 48-57 [PMID:12065754]

143. Espinosa F, Marks G, Heintz $N$ and Joho RH. (2004) Increased motor drive and sleep loss in mice lacking Kv3-type potassium channels. Genes Brain Behav. 3: 90-100 [PMID:15005717]

144. Espinosa F, McMahon A, Chan E, Wang S, Ho CS, Heintz N and Joho RH. (2001) Alcohol hypersensitivity, increased locomotion, and spontaneous myoclonus in mice lacking the potassium channels Kv3.1 and Kv3.3. J. Neurosci. 21: 6657-65 [PMID:11517255]

145. Espinosa F, Torres-Vega MA, Marks GA and Joho RH. (2008) Ablation of Kv3.1 and Kv3.3 potassium channels disrupts thalamocortical oscillations in vitro and in vivo. J. Neurosci. 28: 5570-81 [PMID:18495891]

146. Eunson LH, Rea R, Zuberi SM, Youroukos S, Panayiotopoulos CP, Liguori R, Avoni P, McWilliam RC, 
Stephenson JB and Hanna MG et al.. (2000) Clinical, genetic, and expression studies of mutations in the potassium channel gene KCNA1 reveal new phenotypic variability. Ann. Neurol. 48: 647-56 [PMID:11026449]

147. Fadool DA and Levitan IB. (1998) Modulation of olfactory bulb neuron potassium current by tyrosine phosphorylation. J. Neurosci. 18: 6126-37 [PMID:9698307]

148. Fadool DA, Tucker K, Perkins R, Fasciani G, Thompson RN, Parsons AD, Overton JM, Koni PA, Flavell RA and Kaczmarek LK. (2004) Kv1.3 channel gene-targeted deletion produces "Super-Smeller Mice" with altered glomeruli, interacting scaffolding proteins, and biophysics. Neuron 41: 389-404 [PMID:14766178]

149. Faivre JF, Calmels TP, Rouanet S, Javré JL, Cheval B and Bril A. (1999) Characterisation of Kv4.3 in HEK293 cells: comparison with the rat ventricular transient outward potassium current. Cardiovasc. Res. 41: 188-99 [PMID:10325966]

150. Fantozzi I, Platoshyn O, Wong AH, Zhang S, Remillard CV, Furtado MR, Petrauskene OV and Yuan JX. (2006) Bone morphogenetic protein-2 upregulates expression and function of voltage-gated $\mathrm{K}+$ channels in human pulmonary artery smooth muscle cells. Am. J. Physiol. Lung Cell Mol. Physiol. 291: L993-1004 [PMID:16815889]

151. Farias LM, Ocaña DB, Díaz L, Larrea F, Avila-Chávez E, Cadena A, Hinojosa LM, Lara G, Villanueva LA, Vargas C, Hernández-Gallegos E, Camacho-Arroyo I, Dueñas-González A, Pérez-Cárdenas E, Pardo LA, Morales A, Taja-Chayeb L, Escamilla J, Sánchez-Peña C and Camacho J. (2004) Ether a go-go potassium channels as human cervical cancer markers. Cancer Res. 64: 6996-7001 [PMID:15466192]

152. Farrelly AM, Ro S, Callaghan BP, Khoyi MA, Fleming N, Horowitz B, Sanders KM and Keef KD. (2003) Expression and function of KCNH2 (HERG) in the human jejunum. Am. J. Physiol. Gastrointest. Liver Physiol. 284: G883-95 [PMID:12736144]

153. Fedida D, Wible B, Wang Z, Fermini B, Faust F, Nattel S and Brown AM. (1993) Identity of a novel delayed rectifier current from human heart with a cloned K+ channel current. Circ. Res. 73: 210-6 [PMID:8508531]

154. Felix JP, Bugianesi RM, Schmalhofer WA, Borris R, Goetz MA, Hensens OD, Bao JM, Kayser F, Parsons WH and Rupprecht $\mathrm{K}$ et al.. (1999) Identification and biochemical characterization of a novel nortriterpene inhibitor of the human lymphocyte voltage-gated potassium channel, Kv1.3. Biochemistry 38: 4922-30 [PMID:10213593]

155. Felix R, Serrano CJ, Treviño CL, Muñoz-Garay C, Bravo A, Navarro A, Pacheco J, Tsutsumi V and Darszon A. (2002) Identification of distinct $\mathrm{K}+$ channels in mouse spermatogenic cells and sperm. Zygote 10: 183-8 [PMID:12056459]

156. Feng J, Wible B, Li GR, Wang Z and Nattel S. (1997) Antisense oligodeoxynucleotides directed against Kv1.5 mRNA specifically inhibit ultrarapid delayed rectifier $\mathrm{K}+$ current in cultured adult human atrial myocytes. Circ. Res. 80: 572-9 [PMID:9118489]

157. Fernandez FR, Morales E, Rashid AJ, Dunn RJ and Turner RW. (2003) Inactivation of Kv3.3 potassium channels in heterologous expression systems. J. Biol. Chem. 278: 40890-8 [PMID:12923191]

158. Feske S, Wulff $\mathrm{H}$ and Skolnik EY. (2015) lon channels in innate and adaptive immunity Annu. Rev. Immunol. 33: 291-353 [PMID:25861976]

159. Ficker E, Dennis AT, Wang L and Brown AM. (2003) Role of the cytosolic chaperones Hsp70 and Hsp90 in maturation of the cardiac potassium channel HERG. Circ. Res. 92: e87-100 [PMID:12775586]

160. Ficker E, Jarolimek W, Kiehn J, Baumann A and Brown AM. (1998) Molecular determinants of dofetilide block of HERG K+ channels. Circ. Res. 82: 386-95 [PMID:9486667]

161. Figueroa KP, Minassian NA, Stevanin G, Waters M, Garibyan V, Forlani S, Strzelczyk A, Bürk K, Brice A and Dürr A et al.. (2010) KCNC3: phenotype, mutations, channel biophysics-a study of 260 familial ataxia patients. Hum. Mutat. 31: 191-6 [PMID:19953606]

162. Figueroa KP, Waters MF, Garibyan V, Bird TD, Gomez CM, Ranum LP, Minassian NA, Papazian DM and Pulst SM. (2011) Frequency of KCNC3 DNA variants as causes of spinocerebellar ataxia 13 (SCA13). PLOS ONE 6: e17811 [PMID:21479265]

163. Fink M, Duprat F, Lesage F, Heurteaux C, Romey G, Barhanin J and Lazdunski M. (1996) A new K+ channel beta subunit to specifically enhance Kv2.2 (CDRK) expression. J. Biol. Chem. 271: 26341-8 
[PMID:8824288]

164. Finley MR, Li Y, Hua F, Lillich J, Mitchell KE, Ganta S, Gilmour RF and Freeman LC. (2002) Expression and coassociation of ERG1, KCNQ1, and KCNE1 potassium channel proteins in horse heart. Am. J. Physiol. Heart Circ. Physiol. 283: H126-38 [PMID:12063283]

165. Finol-Urdaneta RK, Remedi MS, Raasch W, Becker S, Clark RB, Strüver N, Pavlov E, Nichols CG, French RJ and Terlau H. (2012) Block of Kv1.7 potassium currents increases glucose-stimulated insulin secretion. EMBO Mol Med 4: 424-34 [PMID:22438204]

166. Finol-Urdaneta RK, Strüver N and Terlau H. (2006) Molecular and Functional Differences between Heart mKv1.7 Channel Isoforms. J. Gen. Physiol. 128: 133-45 [PMID:16801386]

167. Foeger NC, Wang W, Mellor RL and Nerbonne JM. (2013) Stabilization of Kv4 protein by the accessory $\mathrm{K}(+)$ channel interacting protein 2 (KChIP2) subunit is required for the generation of native myocardial fast transient outward K(+) currents. J. Physiol. (Lond.) 591: 4149-66 [PMID:23713033]

168. Folander K, Douglass $J$ and Swanson R. (1994) Confirmation of the assignment of the gene encoding Kv1.3, a voltage-gated potassium channel (KCNA3) to the proximal short arm of human chromosome 1. Genomics 23: 295-6 [PMID:7829094]

169. Fordyce CB, Jagasia R, Zhu X and Schlichter LC. (2005) Microglia Kv1.3 channels contribute to their ability to kill neurons. J. Neurosci. 25: 7139-49 [PMID:16079396]

170. Frank-Hansen R, Larsen LA, Andersen P, Jespersgaard $C$ and Christiansen M. (2005) Mutations in the genes KCND2 and KCND3 encoding the ion channels Kv4.2 and Kv4.3, conducting the cardiac fast transient outward current (ITO,f), are not a frequent cause of long QT syndrome. Clin. Chim. Acta 351: 95100 [PMID:15563876]

171. Franqueza L, Longobardo M, Vicente J, Delpón E, Tamkun MM, Tamargo J, Snyders DJ and Valenzuela C. (1997) Molecular determinants of stereoselective bupivacaine block of hKv1.5 channels. Circ. Res. 81: 1053-64 [PMID:9400387]

172. Franqueza L, Valenzuela C, Delpón E, Longobardo M, Caballero R and Tamargo J. (1998) Effects of propafenone and 5-hydroxy-propafenone on hKv1.5 channels. Br. J. Pharmacol. 125: 969-78 [PMID:9846634]

173. Franqueza L, Valenzuela C, Eck J, Tamkun MM, Tamargo J and Snyders DJ. (1999) Functional expression of an inactivating potassium channel (Kv4.3) in a mammalian cell line. Cardiovasc. Res. 41: 212-9 [PMID:10325968]

174. Frech GC, VanDongen AM, Schuster G, Brown AM and Joho RH. (1989) A novel potassium channel with delayed rectifier properties isolated from rat brain by expression cloning. Nature 340: 642-5 [PMID:2770868]

175. Frey BW, Lynch FT, Kinsella JM, Horowitz B, Sanders KM and Carl A. (2000) Blocking of cloned and native delayed rectifier $\mathrm{K}$ channels from visceral smooth muscles by phencyclidine. Neurogastroenterol. Motil. 12: 509-16 [PMID:11123705]

176. Frings S, Brüll N, Dzeja C, Angele A, Hagen V, Kaupp UB and Baumann A. (1998) Characterization of ether-à-go-go channels present in photoreceptors reveals similarity to $\mathrm{IKx}$, a $\mathrm{K}+$ current in rod inner segments. J. Gen. Physiol. 111: 583-99 [PMID:9524140]

177. Furlan F, Guasti L, Avossa D, Becchetti A, Cilia E, Ballerini L and Arcangeli A. (2005) Interneurons transiently express the ERG K+ channels during development of mouse spinal networks in vitro. Neuroscience 135: 1179-92 [PMID:16165280]

178. Furlan F, Taccola G, Grandolfo M, Guasti L, Arcangeli A, Nistri A and Ballerini L. (2007) ERG conductance expression modulates the excitability of ventral horn GABAergic interneurons that control rhythmic oscillations in the developing mouse spinal cord. J. Neurosci. 27: 919-28 [PMID:17251434]

179. Gaborit N, Steenman M, Lamirault G, Le Meur N, Le Bouter S, Lande G, Léger J, Charpentier F, Christ T and Dobrev $D$ et al.. (2005) Human atrial ion channel and transporter subunit gene-expression remodeling associated with valvular heart disease and atrial fibrillation. Circulation 112: 471-81 [PMID:16027256]

180. Gamper N, Li Y and Shapiro MS. (2005) Structural requirements for differential sensitivity of KCNQ K+ channels to modulation by Ca2+/calmodulin. Mol. Biol. Cell 16: 3538-51 [PMID:15901836] 
181. Gamper N and Shapiro MS. (2007) Regulation of ion transport proteins by membrane phosphoinositides. Nat. Rev. Neurosci. 8: 921-34 [PMID:17971783]

182. Gamper N, Stockand JD and Shapiro MS. (2003) Subunit-specific modulation of KCNQ potassium channels by Src tyrosine kinase. J. Neurosci. 23: 84-95 [PMID:12514204]

183. Gao Z, Zhang T, Wu M, Xiong Q, Sun H, Zhang Y, Zu L, Wang W and Li M. (2010) Isoform-specific prolongation of $\mathrm{Kv} 7$ (KCNQ) potassium channel opening mediated by new molecular determinants for drug-channel interactions. J. Biol. Chem. 285: 28322-32 [PMID:20584905]

184. Garcia-Calvo M, Leonard RJ, Novick J, Stevens SP, Schmalhofer W, Kaczorowski GJ and Garcia ML. (1993) Purification, characterization, and biosynthesis of margatoxin, a component of Centruroides margaritatus venom that selectively inhibits voltage-dependent potassium channels. J. Biol. Chem. 268: 18866-74 [PMID:8360176]

185. García-Ferreiro RE, Kerschensteiner D, Major F, Monje F, Stühmer W and Pardo LA. (2004) Mechanism of block of hEag1 K+ channels by imipramine and astemizole. J. Gen. Physiol. 124: 301-17 [PMID:15365094]

186. Garg V, Stary-Weinzinger A and Sanguinetti MC. (2013) ICA-105574 interacts with a common binding site to elicit opposite effects on inactivation gating of EAG and ERG potassium channels. Mol. Pharmacol. 83: 805-13 [PMID:23319419]

187. Gazula VR, Strumbos JG, Mei X, Chen H, Rahner C and Kaczmarek LK. (2010) Localization of Kv1.3 channels in presynaptic terminals of brainstem auditory neurons. J. Comp. Neurol. 518: 3205-20 [PMID:20575068]

188. Geiger JR and Jonas P. (2000) Dynamic control of presynaptic $\mathrm{Ca}(2+)$ inflow by fast-inactivating $\mathrm{K}(+)$ channels in hippocampal mossy fiber boutons. Neuron 28: 927-39 [PMID:11163277]

189. Gerlach AC, Stoehr SJ and Castle NA. (2010) Pharmacological removal of human ether-à-go-go-related gene potassium channel inactivation by 3-nitro-N-(4-phenoxyphenyl) benzamide (ICA-105574). Mol. Pharmacol. 77: 58-68 [PMID:19805508]

190. Gessner $\mathrm{G}$ and Heinemann SH. (2003) Inhibition of hEAG1 and hERG1 potassium channels by clofilium and its tertiary analogue LY97241. Br. J. Pharmacol. 138: 161-71 [PMID:12522086]

191. Gessner G, Macianskiene R, Starkus JG, Schönherr R and Heinemann SH. (2010) The amiodarone derivative KB130015 activates hERG1 potassium channels via a novel mechanism. Eur. J. Pharmacol. 632: 52-9 [PMID:20097192]

192. Gessner G, Zacharias M, Bechstedt S, Schönherr R and Heinemann SH. (2004) Molecular determinants for high-affinity block of human EAG potassium channels by antiarrhythmic agents. Mol. Pharmacol. 65: 1120-9 [PMID:15102940]

193. Ghanshani S, Pak M, McPherson JD, Strong M, Dethlefs B, Wasmuth JJ, Salkoff L, Gutman GA and Chandy KG. (1992) Genomic organization, nucleotide sequence, and cellular distribution of a Shaw-related potassium channel gene, Kv3.3, and mapping of Kv3.3 and Kv3.4 to human chromosomes 19 and 1. Genomics 12: 190-6 [PMID:1740329]

194. Ghanshani S, Wulff H, Miller MJ, Rohm H, Neben A, Gutman GA, Cahalan MD and Chandy KG. (2000) Up-regulation of the IKCa1 potassium channel during T-cell activation. Molecular mechanism and functional consequences. J. Biol. Chem. 275: 37137-49 [PMID:10961988]

195. Gidh-Jain M, Huang B, Jain P and el-Sherif N. (1996) Differential expression of voltage-gated K+ channel genes in left ventricular remodeled myocardium after experimental myocardial infarction. Circ. Res. 79: 669-75 [PMID:8831490]

196. Gilling M, Rasmussen HB, Calloe K, Sequeira AF, Baretto M, Oliveira G, Almeida J, Lauritsen MB, Ullmann R and Boonen SE et al.. (2013) Dysfunction of the Heteromeric KV7.3/KV7.5 Potassium Channel is Associated with Autism Spectrum Disorders. Front Genet 4: 54 [PMID:23596459]

197. Giudicessi JR, Ye D, Kritzberger CJ, Nesterenko VV, Tester DJ, Antzelevitch C and Ackerman MJ. (2012) Novel mutations in the KCND3-encoded Kv4.3 K+ channel associated with autopsy-negative sudden unexplained death. Hum. Mutat. 33: 989-97 [PMID:22457051]

198. Giudicessi JR, Ye D, Tester DJ, Crotti L, Mugione A, Nesterenko VV, Albertson RM, Antzelevitch C, 
Schwartz PJ and Ackerman MJ. (2011) Transient outward current (I(to)) gain-of-function mutations in the KCND3-encoded Kv4.3 potassium channel and Brugada syndrome. Heart Rhythm 8: 1024-32 [PMID:21349352]

199. Glaudemans B, van der Wijst J, Scola RH, Lorenzoni PJ, Heister A, van der Kemp AW, Knoers NV, Hoenderop JG and Bindels RJ. (2009) A missense mutation in the Kv1.1 voltage-gated potassium channel-encoding gene KCNA1 is linked to human autosomal dominant hypomagnesemia. J. Clin. Invest. 119: 936-42 [PMID:19307729]

200. Glazebrook PA, Ramirez AN, Schild JH, Shieh CC, Doan T, Wible BA and Kunze DL. (2002) Potassium channels Kv1.1, Kv1.2 and Kv1.6 influence excitability of rat visceral sensory neurons. J. Physiol. (Lond.) 541: 467-82 [PMID:12042352]

201. Goldberg EM, Watanabe S, Chang SY, Joho RH, Huang ZJ, Leonard CS and Rudy B. (2005) Specific functions of synaptically localized potassium channels in synaptic transmission at the neocortical GABAergic fast-spiking cell synapse. J. Neurosci. 25: 5230-5 [PMID:15917463]

202. Gong Q, Zhang L, Vincent GM, Horne BD and Zhou Z. (2007) Nonsense mutations in hERG cause a decrease in mutant mRNA transcripts by nonsense-mediated mRNA decay in human long-QT syndrome. Circulation 116: 17-24 [PMID:17576861]

203. Gordon E, Cohen JL, Engel R and Abbott GW. (2006) 1,4-Diazabicyclo[2.2.2]octane derivatives: a novel class of voltage-gated potassium channel blockers. Mol. Pharmacol. 69: 718-26 [PMID:16317109]

204. Gordon E, Lozinskaya IM, Lin Z, Semus SF, Blaney FE, Willette RN and Xu X. (2008) 2-[2-(3,4-dichlorophenyl)-2,3-dihydro-1H-isoindol-5-ylamino]-nicotinic acid (PD-307243) causes instantaneous current through human ether-a-go-go-related gene potassium channels. Mol. Pharmacol. 73: 639-51 [PMID:18042732]

205. Gordon E, Panaghie G, Deng L, Bee KJ, Roepke TK, Krogh-Madsen T, Christini DJ, Ostrer H, Basson CT and Chung W et al.. (2008) A KCNE2 mutation in a patient with cardiac arrhythmia induced by auditory stimuli and serum electrolyte imbalance. Cardiovasc. Res. 77: 98-106 [PMID:18006462]

206. Grigg JJ, Brew HM and Tempel BL. (2000) Differential expression of voltage-gated potassium channel genes in auditory nuclei of the mouse brainstem. Hear. Res. 140: 77-90 [PMID:10675636]

207. Grissmer S, Dethlefs B, Wasmuth JJ, Goldin AL, Gutman GA, Cahalan MD and Chandy KG. (1990) Expression and chromosomal localization of a lymphocyte K+ channel gene. Proc. Natl. Acad. Sci. U.S.A. 87: 9411-5 [PMID:2251283]

208. Grissmer S, Ghanshani S, Dethlefs B, McPherson JD, Wasmuth JJ, Gutman GA, Cahalan MD and Chandy KG. (1992) The Shaw-related potassium channel gene, Kv3.1, on human chromosome 11, encodes the type I K+ channel in T cells. J. Biol. Chem. 267: 20971-9 [PMID:1400413]

209. Grissmer S, Nguyen AN, Aiyar J, Hanson DC, Mather RJ, Gutman GA, Karmilowicz MJ, Auperin DD and Chandy KG. (1994) Pharmacological characterization of five cloned voltage-gated K+ channels, types Kv1.1, 1.2, 1.3, 1.5, and 3.1, stably expressed in mammalian cell lines. Mol. Pharmacol. 45: 1227-34 [PMID:7517498]

210. Grunnet M, Jespersen T, Rasmussen HB, Ljungstrøm T, Jorgensen NK, Olesen SP and Klaerke DA. (2002) KCNE4 is an inhibitory subunit to the KCNQ1 channel. J. Physiol. (Lond.) 542: 119-30 [PMID:12096056]

211. Grupe A, Schröter KH, Ruppersberg JP, Stocker M, Drewes T, Beckh S and Pongs O. (1990) Cloning and expression of a human voltage-gated potassium channel. A novel member of the RCK potassium channel family. EMBO J. 9: 1749-56 [PMID:2347305]

212. Gu N, Vervaeke K, Hu H and Storm JF. (2005) Kv7/KCNQ/M and HCN/h, but not KCa2/SK channels, contribute to the somatic medium after-hyperpolarization and excitability control in CA1 hippocampal pyramidal cells. J. Physiol. (Lond.) 566: 689-715 [PMID:15890705]

213. Gu Y, Barry J, McDougel R, Terman D and Gu C. (2012) Alternative splicing regulates kv3.1 polarized targeting to adjust maximal spiking frequency. J. Biol. Chem. 287: 1755-69 [PMID:22105078]

214. Guan D, Armstrong WE and Foehring RC. (2013) Kv2 channels regulate firing rate in pyramidal neurons from rat sensorimotor cortex. J. Physiol. (Lond.) 591: 4807-25 [PMID:23878373] 
215. Guasti L, Cilia E, Crociani O, Hofmann G, Polvani S, Becchetti A, Wanke E, Tempia F and Arcangeli A. (2005) Expression pattern of the ether-a-go-go-related (ERG) family proteins in the adult mouse central nervous system: evidence for coassembly of different subunits. J. Comp. Neurol. 491: 157-74 [PMID:16127690]

216. Guo J, Wang T, Li X, Shallow H, Yang T, Li W, Xu J, Fridman MD, Yang X and Zhang S. (2012) Cell surface expression of human ether-a-go-go-related gene ( $h E R G$ ) channels is regulated by caveolin-3 protein via the ubiquitin ligase Nedd4-2. J. Biol. Chem. 287: 33132-41 [PMID:22879586]

217. Guo W, Jung WE, Marionneau C, Aimond F, Xu H, Yamada KA, Schwarz TL, Demolombe S and Nerbonne JM. (2005) Targeted deletion of Kv4.2 eliminates I(to,f) and results in electrical and molecular remodeling, with no evidence of ventricular hypertrophy or myocardial dysfunction. Circ. Res. 97: 1342-50 [PMID:16293790]

218. Guo W, Li H, Aimond F, Johns DC, Rhodes KJ, Trimmer JS and Nerbonne JM. (2002) Role of heteromultimers in the generation of myocardial transient outward K+ currents. Circ. Res. 90: 586-93 [PMID:11909823]

219. Guo W, Malin SA, Johns DC, Jeromin A and Nerbonne JM. (2002) Modulation of Kv4-encoded K(+) currents in the mammalian myocardium by neuronal calcium sensor-1. J. Biol. Chem. 277: 26436-43 [PMID:11994284]

220. Guo W, Xu H, London B and Nerbonne JM. (1999) Molecular basis of transient outward K+ current diversity in mouse ventricular myocytes. J. Physiol. (Lond.) 521 Pt 3: 587-99 [PMID:10601491]

221. Guo X, Ma X, Yang Q, Xu J, Huang L, Jia J, Shan J, Liu L, Chen W and Chu łt al.. (2014) Discovery of 1-aryloxyethyl piperazine derivatives as Kv1.5 potassium channel inhibitors (part I). Eur J Med Chem 81: 89-94 [PMID:24824064]

222. Gurrola GB, Hernández-López RA, Rodríguez de la Vega RC, Varga Z, Batista CV, Salas-Castillo SP, Panyi G, del Río-Portilla F and Possani LD. (2012) Structure, function, and chemical synthesis of Vaejovis mexicanus peptide 24: a novel potent blocker of Kv1.3 potassium channels of human T lymphocytes. Biochemistry 51: 4049-61 [PMID:22540187]

223. Gutman GA, Chandy KG, Grissmer S, Lazdunski M, McKinnon D, Pardo LA, Robertson GA, Rudy B, Sanguinetti MC and Stühmer W et al.. (2005) International Union of Pharmacology. LIII. Nomenclature and molecular relationships of voltage-gated potassium channels. Pharmacol. Rev. 57: 473-508 [PMID:16382104]

224. Gómez-Varela D, Contreras-Jurado C, Furini S, García-Ferreiro R, Stühmer W and Pardo LA. (2006) Different relevance of inactivation and F468 residue in the mechanisms of hEag1 channel blockage by astemizole, imipramine and dofetilide. FEBS Lett. 580: 5059-66 [PMID:16949586]

225. Gómez-Varela D, Zwick-Wallasch E, Knötgen H, Sánchez A, Hettmann T, Ossipov D, Weseloh R, Contreras-Jurado C, Rothe M and Stühmer W et al.. (2007) Monoclonal antibody blockade of the human Eag1 potassium channel function exerts antitumor activity. Cancer Res. 67: 7343-9 [PMID:17671204]

226. Göpel SO, Kanno T, Barg S and Rorsman P. (2000) Patch-clamp characterisation of somatostatinsecreting -cells in intact mouse pancreatic islets. J. Physiol. (Lond.) 528: 497-507 [PMID:11060127]

227. Haas M, Ward DC, Lee J, Roses AD, Clarke V, D'Eustachio P, Lau D, Vega-Saenz de Miera E and Rudy B. (1993) Localization of Shaw-related K+ channel genes on mouse and human chromosomes. Mamm. Genome 4: 711-5 [PMID:8111118]

228. Hadley JK, Noda M, Selyanko AA, Wood IC, Abogadie FC and Brown DA. (2000) Differential tetraethylammonium sensitivity of KCNQ1-4 potassium channels. Br. J. Pharmacol. 129: 413-5 [PMID:10711337]

229. Hadley JK, Passmore GM, Tatulian L, Al-Qatari M, Ye F, Wickenden AD and Brown DA. (2003) Stoichiometry of expressed KCNQ2/KCNQ3 potassium channels and subunit composition of native ganglionic M channels deduced from block by tetraethylammonium. J. Neurosci. 23: 5012-9 [PMID:12832524]

230. Haffner CD, Thomson SA, Guo Y, Schaller LT, Boggs S, Dickerson S, Gobel J, Gillie D and Condreay JP. (2010) N-\{3-[(1,1-dioxido-1,2-benzothiazol-3-yl)(phenyl)amino]propyl\}benzamide analogs as potent Kv1.3 
inhibitors. Part 1. Bioorg. Med. Chem. Lett. 20: 6983-8 [PMID:20971642]

231. Haitin Y and Attali B. (2008) The C-terminus of Kv7 channels: a multifunctional module.J. Physiol. (Lond.) 586: 1803-10 [PMID:18218681]

232. Han W, Nattel S, Noguchi T and Shrier A. (2006) C-terminal domain of Kv4.2 and associated KChIP2 interactions regulate functional expression and gating of Kv4.2. J. Biol. Chem. 281: 27134-44 [PMID:16820361]

233. Hanada T, Lin L, Chandy KG, Oh SS and Chishti AH. (1997) Human homologue of the Drosophila discs large tumor suppressor binds to p56lck tyrosine kinase and Shaker type Kv1.3 potassium channel in T lymphocytes. J. Biol. Chem. 272: 26899-904 [PMID:9341123]

234. Hanner M, Schmalhofer WA, Green B, Bordallo C, Liu J, Slaughter RS, Kaczorowski GJ and Garcia ML. (1999) Binding of correolide to $K(v) 1$ family potassium channels. Mapping the domains of high affinity interaction. J. Biol. Chem. 274: 25237-44 [PMID:10464244]

235. Hansen RS, Diness TG, Christ T, Demnitz J, Ravens U, Olesen SP and Grunnet M. (2006) Activation of human ether-a-go-go-related gene potassium channels by the diphenylurea 1,3-bis-(2-hydroxy-5trifluoromethyl-phenyl)-urea (NS1643). Mol. Pharmacol. 69: 266-77 [PMID:16219910]

236. Hansen RS, Diness TG, Christ T, Wettwer E, Ravens U, Olesen SP and Grunnet M. (2006) Biophysical characterization of the new human ether-a-go-go-related gene channel opener NS3623 [N-(4-bromo-2(1H-tetrazol-5-yl)-phenyl)-N'-(3'-trifluoromethylphenyl)urea]. Mol. Pharmacol. 70: 1319-29 [PMID:16825484]

237. Harrell MD, Harbi S, Hoffman JF, Zavadil J and Coetzee WA. (2007) Large-scale analysis of ion channel gene expression in the mouse heart during perinatal development. Physiol. Genomics 28: 273-83 [PMID:16985003]

238. Hartmann HA, Kirsch GE, Drewe JA, Taglialatela M, Joho RH and Brown AM. (1991) Exchange of conduction pathways between two related K+ channels. Science 251: 942-4 [PMID:2000495]

239. Harvey AL. (2001) Twenty years of dendrotoxins. Toxicon 39: 15-26 [PMID:10936620]

240. Hatano N, Ohya S and Imaizumi Y. (2002) Functional interaction between KChIP1 and GFP-fused Kv4.3L co-expressed in HEK293 cells. Pflugers Arch. 444: 80-8 [PMID:11976919]

241. Hatano N, Ohya S, Muraki K, Giles W and Imaizumi Y. (2003) Dihydropyridine Ca2+ channel antagonists and agonists block Kv4.2, Kv4.3 and Kv1.4 K+ channels expressed in HEK293 cells. Br. J. Pharmacol. 139: 533-44 [PMID:12788813]

242. Hattan D, Nesti E, Cachero TG and Morielli AD. (2002) Tyrosine phosphorylation of Kv1.2 modulates its interaction with the actin-binding protein cortactin. J. Biol. Chem. 277: 38596-606 [PMID:12151401]

243. He Y, Kang Y, Leung YM, Xia F, Gao X, Xie H, Gaisano HY and Tsushima RG. (2006) Modulation of Kv2.1 channel gating and TEA sensitivity by distinct domains of SNAP-25. Biochem. J. 396: 363-9 [PMID:16478442]

244. Heinemann SH, Rettig J, Graack HR and Pongs O. (1996) Functional characterization of Kv channel betasubunits from rat brain. J. Physiol. (Lond.) 493 ( Pt 3): 625-33 [PMID:8799886]

245. Heitzmann D, Grahammer F, von Hahn T, Schmitt-Gräff A, Romeo E, Nitschke R, Gerlach U, Lang HJ, Verrey $\mathrm{F}$ and Barhanin J et al.. (2004) Heteromeric KCNE2/KCNQ1 potassium channels in the luminal membrane of gastric parietal cells. J. Physiol. (Lond.) 561: 547-57 [PMID:15579540]

246. Helms LM, Felix JP, Bugianesi RM, Garcia ML, Stevens S, Leonard RJ, Knaus HG, Koch R, Wanner SG and Kaczorowski GJ et al.. (1997) Margatoxin binds to a homomultimer of K(V)1.3 channels in Jurkat cells. Comparison with $\mathrm{K}(\mathrm{V}) 1.3$ expressed in $\mathrm{CHO}$ cells. Biochemistry 36: 3737-44 [PMID:9132027]

247. Hemmerlein B, Weseloh RM, Mello de Queiroz F, Knötgen H, Sánchez A, Rubio ME, Martin S, Schliephacke T, Jenke M, Heinz-Joachim-Radzun W and Pardo LA. (2006) Overexpression of Eag1 potassium channels in clinical tumours. Mol. Cancer 5: 41 [PMID:17022810]

248. Hemmick LM, Perney TM, Flamm RE, Kaczmarek LK and Birnberg NC. (1992) Expression of the H-ras oncogene induces potassium conductance and neuron-specific potassium channel mRNAs in the AtT20 cell line. J. Neurosci. 12: 2007-14 [PMID:1607925]

249. Hermanstyne TO, Kihira Y, Misono K, Deitchler A, Yanagawa Y and Misonou H. (2010) 
Immunolocalization of the voltage-gated potassium channel Kv2.2 in GABAergic neurons in the basal forebrain of rats and mice. J. Comp. Neurol. 518: 4298-310 [PMID:20853508]

250. Hernandez CC, Zaika O, Tolstykh GP and Shapiro MS. (2008) Regulation of neural KCNQ channels: signalling pathways, structural motifs and functional implications. J. Physiol. (Lond.) 586: 1811-21 [PMID:18238808]

251. Hernández-Pineda R, Chow A, Amarillo $Y$, Moreno H, Saganich M, Vega-Saenz de Miera EC, HernándezCruz A and Rudy B. (1999) Kv3.1-Kv3.2 channels underlie a high-voltage-activating component of the delayed rectifier K+ current in projecting neurons from the globus pallidus. J. Neurophysiol. 82: 1512-28 [PMID:10482766]

252. Herrington J, Solly K, Ratliff KS, Li N, Zhou YP, Howard A, Kiss L, Garcia ML, McManus OB and Deng Q et al.. (2011) Identification of novel and selective Kv2 channel inhibitors.Mol. Pharmacol. 80: 959-64 [PMID:21948463]

253. Herrington J, Zhou YP, Bugianesi RM, Dulski PM, Feng Y, Warren VA, Smith MM, Kohler MG, Garsky VM and Sanchez M et al.. (2006) Blockers of the delayed-rectifier potassium current in pancreatic beta-cells enhance glucose-dependent insulin secretion. Diabetes 55: 1034-42 [PMID:16567526]

254. Herrmann M, Ruprecht K, Sauter M, Martinez J, van Heteren P, Glas M, Best B, Meyerhans A, Roemer K and Mueller-Lantzsch N. (2010) Interaction of human immunodeficiency virus gp120 with the voltage-gated potassium channel BEC1. FEBS Lett. 584: 3513-8 [PMID:20638388]

255. Herrmann S, Ninkovic M, Kohl T, Lörinczi É and Pardo LA. (2012) Cortactin controls surface expression of the voltage-gated potassium channel K(V)10.1. J. Biol. Chem. 287: 44151-63 [PMID:23144454]

256. Herrmann S, Ninkovic M, Kohl T and Pardo LA. (2013) PIST (GOPC) modulates the oncogenic voltagegated potassium channel KV10.1. Front Physiol 4: 201 [PMID:23966943]

257. Herson PS, Virk M, Rustay NR, Bond CT, Crabbe JC, Adelman JP and Maylie J. (2003) A mouse model of episodic ataxia type-1. Nat. Neurosci. 6: 378-83 [PMID:12612586]

258. Herzberg IM, Trudeau MC and Robertson GA. (1998) Transfer of rapid inactivation and sensitivity to the class III antiarrhythmic drug E-4031 from HERG to M-eag channels. J. Physiol. (Lond.) 511 ( Pt 1): 3-14 [PMID:9679158]

259. Hill AP, Sunde M, Campbell TJ and Vandenberg Jl. (2007) Mechanism of block of the hERG K+ channel by the scorpion toxin CnErg1. Biophys. J. 92: 3915-29 [PMID:17369411]

260. Ho CS, Grange RW and Joho RH. (1997) Pleiotropic effects of a disrupted K+ channel gene: reduced body weight, impaired motor skill and muscle contraction, but no seizures. Proc. Natl. Acad. Sci. U.S.A.94: 1533-8 [PMID:9037088]

261. Holmes TC, Fadool DA, Ren R and Levitan IB. (1996) Association of Src tyrosine kinase with a human potassium channel mediated by SH3 domain. Science 274: 2089-91 [PMID:8953041]

262. Holmqvist MH, Cao J, Hernandez-Pineda R, Jacobson MD, Carroll KI, Sung MA, Betty M, Ge P, Gilbride $\mathrm{KJ}$ and Brown ME et al.. (2002) Elimination of fast inactivation in Kv4 A-type potassium channels by an auxiliary subunit domain. Proc. Natl. Acad. Sci. U.S.A. 99: 1035-40 [PMID:11805342]

263. Holmqvist MH, Cao J, Knoppers MH, Jurman ME, Distefano PS, Rhodes KJ, Xie Y and An WF. (2001) Kinetic modulation of Kv4-mediated A-current by arachidonic acid is dependent on potassium channel interacting proteins. J. Neurosci. 21: 4154-61 [PMID:11404400]

264. Hong K, Piper DR, Diaz-Valdecantos A, Brugada J, Oliva A, Burashnikov E, Santos-de-Soto J, GruesoMontero J, Diaz-Enfante E and Brugada P et al.. (2005) De novo KCNQ1 mutation responsible for atrial fibrillation and short QT syndrome in utero. Cardiovasc. Res. 68: 433-40 [PMID:16109388]

265. Hopkins WF, Allen ML, Houamed KM and Tempel BL. (1994) Properties of voltage-gated K+ currents expressed in Xenopus oocytes by mKv1.1, mKv1.2 and their heteromultimers as revealed by mutagenesis of the dendrotoxin-binding site in mKv1.1. Pflugers Arch. 428: 382-90 [PMID:7816560]

266. Hoppe UC, Johns DC, Marbán E and O'Rourke B. (1999) Manipulation of cellular excitability by cell fusion: effects of rapid introduction of transient outward K+ current on the guinea pig action potential. Circ. Res.

84: 964-72 [PMID:10222344]

267. Hoshi N, Takahashi H, Shahidullah M, Yokoyama S and Higashida H. (1998) KCR1, a membrane protein 
that facilitates functional expression of non-inactivating $\mathrm{K}+$ currents associates with rat EAG voltagedependent K+ channels. J. Biol. Chem. 273: 23080-5 [PMID:9722534]

268. Hu HJ, Carrasquillo Y, Karim F, Jung WE, Nerbonne JM, Schwarz TL and Gereau 4th RW. (2006) The kv4.2 potassium channel subunit is required for pain plasticity. Neuron 50: 89-100 [PMID:16600858]

269. Huang B, Qin D and El-Sherif N. (2001) Spatial alterations of Kv channels expression and K(+) currents in post-MI remodeled rat heart. Cardiovasc. Res. 52: 246-54 [PMID:11684072]

270. Huang $\mathrm{H}$ and Trussell LO. (2011) KCNQ5 channels control resting properties and release probability of a synapse. Nat. Neurosci. 14: 840-7 [PMID:21666672]

271. Huang X, He Y, Dubuc AM, Hashizume R, Zhang W, Reimand J, Yang H, Wang TA, Stehbens SJ, Younger S, Barshow S, Zhu S, Cooper MK, Peacock J, Ramaswamy V, Garzia L, Wu X, Remke M, Forester, CM, Kim CC, Weiss WA, James CD, Shuman MA, Bader GD, Mueller S, Taylor MD, Jan YN and Jan LY. EAG2 potassium channel with evolutionarily conserved function as a brain tumor target. Nature Neurosci.

272. Huffaker SJ, Chen J, Nicodemus KK, Sambataro F, Yang F, Mattay V, Lipska BK, Hyde TM, Song J and Rujescu D et al.. (2009) A primate-specific, brain isoform of KCNH2 affects cortical physiology, cognition, neuronal repolarization and risk of schizophrenia. Nat. Med. 15: 509-18 [PMID:19412172]

273. Hugnot JP, Salinas M, Lesage F, Guillemare E, de Weille J, Heurteaux C, Mattéi MG and Lazdunski M. (1996) Kv8.1, a new neuronal potassium channel subunit with specific inhibitory properties towards Shab and Shaw channels. EMBO J. 15: 3322-31 [PMID:8670833]

274. Hulme JT, Coppock EA, Felipe A, Martens JR and Tamkun MM. (1999) Oxygen sensitivity of cloned voltage-gated $\mathrm{K}(+)$ channels expressed in the pulmonary vasculature. Circ. Res. 85: 489-97 [PMID:10488051]

275. Hurlock EC, Bose M, Pierce G and Joho RH. (2009) Rescue of motor coordination by Purkinje celltargeted restoration of Kv3.3 channels in Kcnc3-null mice requires Kcnc1. J. Neurosci. 29: 15735-44 [PMID:20016089]

276. Hurlock EC, McMahon A and Joho RH. (2008) Purkinje-cell-restricted restoration of Kv3.3 function restores complex spikes and rescues motor coordination in Kcnc3 mutants. J. Neurosci. 28: 4640-8 [PMID:18448641]

277. Hurst RS, Busch AE, Kavanaugh MP, Osborne PB, North RA and Adelman JP. (1991) Identification of amino acid residues involved in dendrotoxin block of rat voltage-dependent potassium channels. Mol. Pharmacol. 40: 572-6 [PMID:1921987]

278. Hwang PM, Fotuhi M, Bredt DS, Cunningham AM and Snyder SH. (1993) Contrasting immunohistochemical localizations in rat brain of two novel K+ channels of the Shab subfamily. $J$. Neurosci. 13: 1569-76 [PMID:8463836]

279. Hwang PM, Glatt CE, Bredt DS, Yellen G and Snyder SH. (1992) A novel K+ channel with unique localizations in mammalian brain: molecular cloning and characterization. Neuron 8: 473-81 [PMID:1550672]

280. Höltje M, Brunk I, Grosse J, Beyer E, Veh RW, Bergmann M, Grosse G and Ahnert-Hilger G. (2007) Differential distribution of voltage-gated potassium channels $\mathrm{Kv} 1.1-\mathrm{Kv} 1.6$ in the rat retina during development. J. Neurosci. Res. 85: 19-33 [PMID:17075900]

281. Iannotti FA, Silvestri C, Mazzarella E, Martella A, Calvigioni D, Piscitelli F, Ambrosino P, Petrosino S, Czifra $G$ and Bíró T et al.. (2014) The endocannabinoid 2-AG controls skeletal muscle cell differentiation via CB1 receptor-dependent inhibition of Kv7 channels. Proc. Natl. Acad. Sci. U.S.A. 111: E2472-81 [PMID:24927567]

282. Imperial JS, Chen P, Sporning A, Terlau H, Daly NL, Craik DJ, Alewood PF and Olivera BM. (2008) Tyrosine-rich conopeptides affect voltage-gated K+ channels. J. Biol. Chem. 283: 23026-32 [PMID:18505731]

283. Isbrandt D, Leicher T, Waldschütz R, Zhu X, Luhmann U, Michel U, Sauter K and Pongs O. (2000) Gene structures and expression profiles of three human KCND (Kv4) potassium channels mediating A-type currents I(TO) and I(SA). Genomics 64: 144-54 [PMID:10729221] 
284. Ishikawa T, Nakamura Y, Saitoh N, Li WB, Iwasaki S and Takahashi T. (2003) Distinct roles of Kv1 and Kv3 potassium channels at the calyx of Held presynaptic terminal. J. Neurosci. 23: 10445-53 [PMID:14614103]

285. Itri JN, Michel S, Vansteensel MJ, Meijer JH and Colwell CS. (2005) Fast delayed rectifier potassium current is required for circadian neural activity. Nat. Neurosci. 8: 650-6 [PMID:15852012]

286. Iwasa H, Kurabayashi M, Nagai R, Nakamura $Y$ and Tanaka T. (2001) Genetic variations in five genes involved in the excitement of cardiomyocytes. J. Hum. Genet. 46: 549-52 [PMID:11558906]

287. Iwasa H, Kurabayashi M, Nagai R, Nakamura Y and Tanaka T. (2001) Multiple single-nucleotide polymorphisms (SNPs) in the Japanese population in six candidate genes for long QT syndrome. J. Hum. Genet. 46: 158-62 [PMID:11310586]

288. I wasaki YK, Yamashita T, Sekiguchi A, Hatano S, Sagara K, linuma H, Fu LT, Kobayashi Y, Katoh T and Takano T. (2006) A method for the simultaneous analysis of mRNA levels of multiple cardiac ion channels with a multi-probe RNase protection assay. Europace 8: 1011-5 [PMID:17005589]

289. Jacob A, Hurley IR, Goodwin LO, Cooper GW and Benoff S. (2000) Molecular characterization of a voltage-gated potassium channel expressed in rat testis. Mol. Hum. Reprod. 6: 303-13 [PMID:10729311]

290. Jacobson DA, Kuznetsov A, Lopez JP, Kash S, Ammälä CE and Philipson LH. (2007) Kv2.1 ablation alters glucose-induced islet electrical activity, enhancing insulin secretion. Cell Metab. 6: 229-35 [PMID:17767909]

291. Jang GM, Leong LE, Hoang LT, Wang PH, Gutman GA and Semler BL. (2004) Structurally distinct elements mediate internal ribosome entry within the 5 '-noncoding region of a voltage-gated potassium channel mRNA. J. Biol. Chem. 279: 47419-30 [PMID:15339906]

292. Jenke M, Sánchez A, Monje F, Stühmer W, Weseloh RM and Pardo LA. (2003) C-terminal domains implicated in the functional surface expression of potassium channels. EMBO J. 22: 395-403 [PMID:12554641]

293. Jensen HS, Callø K, Jespersen T, Jensen BS and Olesen SP. (2005) The KCNQ5 potassium channel from mouse: a broadly expressed $\mathrm{M}$-current like potassium channel modulated by zinc, $\mathrm{pH}$, and volume changes. Brain Res. Mol. Brain Res. 139: 52-62 [PMID:15963599]

294. Jerng HH, Pfaffinger PJ and Covarrubias M. (2004) Molecular physiology and modulation of somatodendritic A-type potassium channels. Mol. Cell. Neurosci. 27: 343-69 [PMID:15555915]

295. Jerng HH, Qian Y and Pfaffinger PJ. (2004) Modulation of Kv4.2 channel expression and gating by dipeptidyl peptidase 10 (DPP10). Biophys. J. 87: 2380-96 [PMID:15454437]

296. Jerng HH, Shahidullah M and Covarrubias M. (1999) Inactivation gating of Kv4 potassium channels: molecular interactions involving the inner vestibule of the pore. J. Gen. Physiol. 113: 641-60 [PMID:10228180]

297. Jiang B, Sun X, Cao K and Wang R. (2002) Endogenous Kv channels in human embryonic kidney (HEK293) cells. Mol. Cell. Biochem. 238: 69-79 [PMID:12349911]

298. Jiang M, Tseng-Crank J and Tseng GN. (1997) Suppression of slow delayed rectifier current by a truncated isoform of KvLQT1 cloned from normal human heart. J. Biol. Chem. 272: 24109-12 [PMID:9305853]

299. Jiao S, Liu Z, Ren WH, Ding Y, Zhang YQ, Zhang ZH and Mei YA. (2007) cAMP/protein kinase A signalling pathway protects against neuronal apoptosis and is associated with modulation of Kv2.1 in cerebellar granule cells. J. Neurochem. 100: 979-91 [PMID:17156132]

300. Jin HW, Zhang W, Qu LT and Wang XL. (2003) [Electrophysiological correspondence between Kv4.2 current and transient outward potassium current in the cultured rat hippocampal neuron]. Sheng Li Xue Bao 55: 711-6 [PMID:14695490]

301. Johnston J, Griffin SJ, Baker C, Skrzypiec A, Chernova T and Forsythe ID. (2008) Initial segment Kv2.2 channels mediate a slow delayed rectifier and maintain high frequency action potential firing in medial nucleus of the trapezoid body neurons. J. Physiol. (Lond.) 586: 3493-509 [PMID:18511484]

302. Joho RH, Marks GA and Espinosa F. (2006) Kv3 potassium channels control the duration of different arousal states by distinct stochastic and clock-like mechanisms. Eur. J. Neurosci. 23: 1567-74 
[PMID:16553620]

303. Joho RH, Street C, Matsushita S and Knöpfel T. (2006) Behavioral motor dysfunction in Kv3-type potassium channel-deficient mice. Genes Brain Behav. 5: 472-82 [PMID:16923152]

304. Jones EM, Roti Roti EC, Wang J, Delfosse SA and Robertson GA. (2004) Cardiac IKr channels minimally comprise hERG 1a and 1b subunits. J. Biol. Chem. 279: 44690-4 [PMID:15304481]

305. Jorge BS, Campbell CM, Miller AR, Rutter ED, Gurnett CA, Vanoye CG, George Jr AL and Kearney JA. (2011) Voltage-gated potassium channel KCNV2 (Kv8.2) contributes to epilepsy susceptibility. Proc. Natl. Acad. Sci. U.S.A. 108: 5443-8 [PMID:21402906]

306. Jow F and Wang K. (2000) Cloning and functional expression of rKCNQ2 K(+) channel from rat brain. Brain Res. Mol. Brain Res. 80: 269-78 [PMID:11038262]

307. Ju M and Wray D. (2002) Molecular identification and characterisation of the human eag2 potassium channel. FEBS Lett. 524: 204-10 [PMID:12135768]

308. Jung DK, Lee SY, Kim D, Joo KM, Cha Cl, Yang HS, Lee WB and Chung YH. (2005) Age-related changes in the distribution of Kv1.1 and Kv3.1 in rat cochlear nuclei. Neurol. Res. 27: 436-40 [PMID:15949244]

309. Kalman K, Nguyen A, Tseng-Crank J, Dukes ID, Chandy G, Hustad CM, Copeland NG, Jenkins NA, Mohrenweiser $\mathrm{H}$ and Brandriff $\mathrm{B}$ et al.. (1998) Genomic organization, chromosomal localization, tissue distribution, and biophysical characterization of a novel mammalian Shaker-related voltage-gated potassium channel, Kv1.7. J. Biol. Chem. 273: 5851-7 [PMID:9488722]

310. Kalman K, Pennington MW, Lanigan MD, Nguyen A, Rauer H, Mahnir V, Paschetto K, Kem WR, Grissmer S and Gutman GA et al.. (1998) ShK-Dap22, a potent Kv1.3-specific immunosuppressive polypeptide.J. Biol. Chem. 273: 32697-707 [PMID:9830012]

311. Kamb A, Weir M, Rudy B, Varmus $H$ and Kenyon C. (1989) Identification of genes from pattern formation, tyrosine kinase, and potassium channel families by DNA amplification. Proc. Natl. Acad. Sci. U.S.A. 86: 4372-6 [PMID:2734290]

312. Kanemasa T, Gan L, Perney TM, Wang LY and Kaczmarek LK. (1995) Electrophysiological and pharmacological characterization of a mammalian Shaw channel expressed in NIH 3T3 fibroblasts. J. Neurophysiol. 74: 207-17 [PMID:7472324]

313. Kang J, Chen XL, Wang H, Ji J, Cheng H, Incardona J, Reynolds W, Viviani F, Tabart M and Rampe D. (2005) Discovery of a small molecule activator of the human ether-a-go-go-related gene (HERG) cardiac K+ channel. Mol. Pharmacol. 67: 827-36 [PMID:15548764]

314. Kaprielian R, Wickenden AD, Kassiri Z, Parker TG, Liu PP and Backx PH. (1999) Relationship between K+ channel down-regulation and [Ca2+]i in rat ventricular myocytes following myocardial infarction. J. Physiol. (Lond.) 517 ( Pt 1): 229-45 [PMID:10226162]

315. Kashuba VI, Kvasha SM, Protopopov Al, Gizatullin RZ, Rynditch AV, Wahlestedt C, Wasserman WW and Zabarovsky ER. (2001) Initial isolation and analysis of the human Kv1.7 (KCNA7) gene, a member of the voltage-gated potassium channel gene family. Gene 268: 115-22 [PMID:11368907]

316. Kazmierczak M, Zhang X, Chen B, Mulkey DK, Shi Y, Wagner PG, Pivaroff-Ward K, Sassic JK, Bayliss DA and Jegla T. (2013) External pH modulates EAG superfamily K+ channels through EAG-specific acidic residues in the voltage sensor. J. Gen. Physiol. 141: 721-35 [PMID:23712551]

317. Keating MT and Sanguinetti MC. (2001) Molecular and cellular mechanisms of cardiac arrhythmias.Cell 104: 569-80 [PMID:11239413]

318. Kerschensteiner D and Stocker M. (1999) Heteromeric assembly of Kv2.1 with Kv9.3: effect on the state dependence of inactivation. Biophys. J. 77: 248-57 [PMID:10388754]

319. Keserü GM. (2003) Prediction of hERG potassium channel affinity by traditional and hologram qSAR methods. Bioorg. Med. Chem. Lett. 13: 2773-5 [PMID:12873512]

320. Khanna R, Roy L, Zhu X and Schlichter LC. (2001) K+ channels and the microglial respiratory burst Am. J. Physiol., Cell Physiol. 280: C796-806 [PMID:11245596]

321. Kharkovets T, Hardelin JP, Safieddine S, Schweizer M, El-Amraoui A, Petit C and Jentsch TJ. (2000) KCNQ4, a K+ channel mutated in a form of dominant deafness, is expressed in the inner ear and the central auditory pathway. Proc. Natl. Acad. Sci. U.S.A. 97: 4333-8 [PMID:10760300] 
322. Kihira Y, Hermanstyne TO and Misonou H. (2010) Formation of heteromeric Kv2 channels in mammalian brain neurons. J. Biol. Chem. 285: 15048-55 [PMID:20202934]

323. Kim E, Niethammer M, Rothschild A, Jan YN and Sheng M. (1995) Clustering of Shaker-type K+ channels by interaction with a family of membrane-associated guanylate kinases. Nature 378: 85-8 [PMID:7477295]

324. Kim E and Sheng M. (1996) Differential K+ channel clustering activity of PSD-95 and SAP97, two related membrane-associated putative guanylate kinases. Neuropharmacology 35: 993-1000 [PMID:8938729]

325. Kim SE, Ahn HS, Choi BH, Jang HJ, Kim MJ, Rhie DJ, Yoon SH, Jo YH, Kim MS, Sung KW and Hahn SJ. (2007) Open channel block of A-type, kv4.3, and delayed rectifier K+ channels, Kv1.3 and Kv3.1, by sibutramine. J. Pharmacol. Exp. Ther. 321: 753-62 [PMID:17312186]

326. Kirchberger NM, Wulfsen I, Schwarz JR and Bauer CK. (2006) Effects of TRH on heteromeric rat erg1a/1b K+ channels are dominated by the rerg1b subunit. J. Physiol. (Lond.) 571: 27-42 [PMID:16339175]

327. Kirsch GE and Drewe JA. (1993) Gating-dependent mechanism of 4-aminopyridine block in two related potassium channels. J. Gen. Physiol. 102: 797-816 [PMID:8301258]

328. Kirsch GE, Drewe JA, Taglialatela M, Joho RH, DeBiasi M, Hartmann HA and Brown AM. (1992) A single nonpolar residue in the deep pore of related $\mathrm{K}+$ channels acts as a $\mathrm{K}+\mathrm{Rb}+$ conductance switch. Biophys. J. 62: 136-43; discussion 143-4 [PMID:1600093]

329. Klemic KG, Kirsch GE and Jones SW. (2001) U-type inactivation of Kv3.1 and Shaker potassium channels. Biophys. J. 81: 814-26 [PMID:11463627]

330. Klocke R, Roberds SL, Tamkun MM, Gronemeier M, Augustin A, Albrecht B, Pongs O and Jockusch H. (1993) Chromosomal mapping in the mouse of eight $\mathrm{K}(+)$-channel genes representing the four Shaker-like subfamilies Shaker, Shab, Shaw, and Shal. Genomics 18: 568-74 [PMID:7905852]

331. Klumpp DJ, Farber DB, Bowes C, Song EJ and Pinto LH. (1991) The potassium channel MBK1 (Kv1.1) is expressed in the mouse retina. Cell. Mol. Neurobiol. 11: 611-22 [PMID:1723658]

332. Klumpp DJ, Song EJ and Pinto LH. (1995) Identification and localization of K+ channels in the mouse retina. Vis. Neurosci. 12: 1177-90 [PMID:8962835]

333. Knobloch K, Brendel J, Peukert S, Rosenstein B, Busch AE and Wirth KJ. (2002) Electrophysiological and antiarrhythmic effects of the novel I(Kur) channel blockers, S9947 and S20951, on left vs. right pig atrium in vivo in comparison with the $\mathrm{I}(\mathrm{Kr})$ blockers dofetilide, azimilide, d, I-sotalol and ibutilide. Naunyn Schmiedebergs Arch. Pharmacol. 366: 482-7 [PMID:12382079]

334. Koch RO, Wanner SG, Koschak A, Hanner M, Schwarzer C, Kaczorowski GJ, Slaughter RS, Garcia ML and Knaus HG. (1997) Complex subunit assembly of neuronal voltage-gated K+ channels. Basis for highaffinity toxin interactions and pharmacology. J. Biol. Chem. 272: 27577-81 [PMID:9346893]

335. Koh SD, Ward SM, Dick GM, Epperson A, Bonner HP, Sanders KM, Horowitz B and Kenyon JL. (1999) Contribution of delayed rectifier potassium currents to the electrical activity of murine colonic smooth muscle. J. Physiol. (Lond.) 515 ( Pt 2): 475-87 [PMID:10050014]

336. Kong W, Po S, Yamagishi T, Ashen MD, Stetten G and Tomaselli GF. (1998) Isolation and characterization of the human gene encoding Ito: further diversity by alternative mRNA splicing. Am. J. Physiol. 275: H1963-70 [PMID:9843794]

337. Koni PA, Khanna R, Chang MC, Tang MD, Kaczmarek LK, Schlichter LC and Flavella RA. (2003) Compensatory anion currents in Kv1.3 channel-deficient thymocytes. J. Biol. Chem. 278: 39443-51 [PMID:12878608]

338. Koo GC, Blake JT, Talento A, Nguyen M, Lin S, Sirotina A, Shah K, Mulvany K, Hora Jr D and Cunningham $P$ et al.. (1997) Blockade of the voltage-gated potassium channel Kv1.3 inhibits immune responses in vivo. J. Immunol. 158: 5120-8 [PMID:9164927]

339. Korn SJ and Ikeda SR. (1995) Permeation selectivity by competition in a delayed rectifier potassium channel. Science 269: 410-2 [PMID:7618108]

340. Korolkova YV, Tseng GN and Grishin EV. (2004) Unique interaction of scorpion toxins with the hERG channel. J. Mol. Recognit. 17: 209-17 [PMID:15137031]

341. Koschak A, Bugianesi RM, Mitterdorfer J, Kaczorowski GJ, Garcia ML and Knaus HG. (1998) Subunit composition of brain voltage-gated potassium channels determined by hongotoxin-1, a novel peptide 
derived from Centruroides limbatus venom. J. Biol. Chem. 273: 2639-44 [PMID:9446567]

342. Kosenko A, Kang S, Smith IM, Greene DL, Langeberg LK, Scott JD and Hoshi N. (2012) Coordinated signal integration at the M-type potassium channel upon muscarinic stimulation. EMBO J. 31: 3147-56 [PMID:22643219]

343. Kotecha SA and Schlichter LC. (1999) A Kv1.5 to Kv1.3 switch in endogenous hippocampal microglia and a role in proliferation. J. Neurosci. 19: 10680-93 [PMID:10594052]

344. Kramer JW, Post MA, Brown AM and Kirsch GE. (1998) Modulation of potassium channel gating by coexpression of Kv2.1 with regulatory Kv5.1 or Kv6.1 alpha-subunits. Am. J. Physiol. 274: C1501-10 [PMID:9696692]

345. Kubisch C, Schroeder BC, Friedrich T, Lütjohann B, El-Amraoui A, Marlin S, Petit C and Jentsch TJ. (1999) KCNQ4, a novel potassium channel expressed in sensory outer hair cells, is mutated in dominant deafness. Cell 96: 437-46 [PMID:10025409]

346. Kulkarni RS, Zorn LJ, Anantharam V, Bayley H and Treistman SN. (1996) Inhibitory effects of ketamine and halothane on recombinant potassium channels from mammalian brain. Anesthesiology 84: 900-9 [PMID:8638845]

347. Kunzelmann K, Hübner M, Schreiber R, Levy-Holzman R, Garty H, Bleich M, Warth R, Slavik M, von Hahn T and Greger R. (2001) Cloning and function of the rat colonic epithelial K+ channel KVLQT1. J. Membr. Biol. 179: 155-64 [PMID:11220365]

348. Kupershmidt S, Yang IC, Hayashi K, Wei J, Chanthaphaychith S, Petersen Cl, Johns DC, George Jr AL, Roden DM and Balser JR. (2003) The IKr drug response is modulated by KCR1 in transfected cardiac and noncardiac cell lines. FASEB J. 17: 2263-5 [PMID:14525949]

349. Kuryshev YA, Wible BA, Gudz TI, Ramirez AN and Brown AM. (2001) KChAP/Kvbeta1.2 interactions and their effects on cardiac Kv channel expression. Am. J. Physiol., Cell Physiol. 281: C290-9 [PMID:11401852]

350. Kääb S, Dixon J, Duc J, Ashen D, Näbauer M, Beuckelmann DJ, Steinbeck G, McKinnon D and Tomaselli GF. (1998) Molecular basis of transient outward potassium current downregulation in human heart failure: a decrease in Kv4.3 mRNA correlates with a reduction in current density. Circulation 98: 1383-93 [PMID:9760292]

351. Lan M, Shi Y, Han Z, Hao Z, Pan Y, Liu N, Guo C, Hong L, Wang J and Qiao Et al.. (2005) Expression of delayed rectifier potassium channels and their possible roles in proliferation of human gastric cancer cells. Cancer Biol. Ther. 4: 1342-7 [PMID:16258262]

352. Lang R, Lee G, Liu W, Tian S, Rafi H, Orias M, Segal AS and Desir GV. (2000) KCNA10: a novel ion channel functionally related to both voltage-gated potassium and CNG cation channels. Am. J. Physiol. Renal Physiol. 278: F1013-21 [PMID:10836990]

353. Lansu K and Gentile S. (2013) Potassium channel activation inhibits proliferation of breast cancer cells by activating a senescence program. Cell Death Dis 4: e652 [PMID:23744352]

354. Lau D, Vega-Saenz de Miera EC, Contreras D, Ozaita A, Harvey M, Chow A, Noebels JL, Paylor R, Morgan JI, Leonard CS and Rudy B. (2000) Impaired fast-spiking, suppressed cortical inhibition, and increased susceptibility to seizures in mice lacking Kv3.2 K+ channel proteins. J. Neurosci. 20: 9071-85 [PMID:11124984]

355. Lecain E, Sauvaget E, Crisanti P, Van Den Abbeele T and Huy PT. (1999) Potassium channel ether à gogo mRNA expression in the spiral ligament of the rat. Hear. Res. 133: 133-8 [PMID:10416871]

356. Lee CW, Kim S, Roh SH, Endoh H, Kodera Y, Maeda T, Kohno T, Wang JM, Swartz KJ and Kim JI. (2004) Solution structure and functional characterization of SGTx1, a modifier of Kv2.1 channel gating. Biochemistry 43: 890-7 [PMID:14744131]

357. Lee H, Lin MC, Kornblum HI, Papazian DM and Nelson SF. (2014) Exome sequencing identifies de novo gain of function missense mutation in KCND2 in identical twins with autism and seizures that slows potassium channel inactivation. Hum. Mol. Genet. 23: 3481-9 [PMID:24501278]

358. Lee HC, Wang JM and Swartz KJ. (2003) Interaction between extracellular Hanatoxin and the resting conformation of the voltage-sensor paddle in Kv channels. Neuron 40: 527-36 [PMID:14642277] 
359. Lee MP, Hu RJ, Johnson LA and Feinberg AP. (1997) Human KVLQT1 gene shows tissue-specific imprinting and encompasses Beckwith-Wiedemann syndrome chromosomal rearrangements. Nat. Genet. 15: 181-5 [PMID:9020845]

360. Lee SI, Conrad T, Jones SM, Lagziel A, Starost MF, Belyantseva IA, Friedman TB and Morell RJ. (2013) A null mutation of mouse Kcna10 causes significant vestibular and mild hearing dysfunction. Hear. Res. 300: 1-9 [PMID:23528307]

361. Lee SY, Maniak PJ, Ingbar DH and O'Grady SM. (2003) Adult alveolar epithelial cells express multiple subtypes of voltage-gated $\mathrm{K}+$ channels that are located in apical membrane. Am. J. Physiol., Cell Physiol. 284: C1614-24 [PMID:12606310]

362. Lee YC, Durr A, Majczenko K, Huang YH, Liu YC, Lien CC, Tsai PC, Ichikawa Y, Goto J and Monin MLet al.. (2012) Mutations in KCND3 cause spinocerebellar ataxia type 22.Ann. Neurol. 72: 859-69 [PMID:23280837]

363. Lees-Miller JP, Duan Y, Teng GQ and Duff HJ. (2000) Molecular determinant of high-affinity dofetilide binding to HERG1 expressed in Xenopus oocytes: involvement of S6 sites. Mol. Pharmacol. 57: 367-74 [PMID:10648647]

364. Leicher T, Bähring R, Isbrandt $D$ and Pongs O. (1998) Coexpression of the KCNA3B gene product with Kv1.5 leads to a novel A-type potassium channel. J. Biol. Chem. 273: 35095-101 [PMID:9857044]

365. Lenz S, Perney TM, Qin Y, Robbins E and Chesselet MF. (1994) GABA-ergic interneurons of the striatum express the Shaw-like potassium channel Kv3.1. Synapse 18: 55-66 [PMID:7825124]

366. Leoni AL, Marionneau C, Demolombe S, Le Bouter S, Mangoni ME, Escande D and Charpentier F. (2005) Chronic heart rate reduction remodels ion channel transcripts in the mouse sinoatrial node but not in the ventricle. Physiol. Genomics 24: 4-12 [PMID:16219869]

367. Lerche C, Scherer CR, Seebohm G, Derst C, Wei AD, Busch AE and Steinmeyer K. (2000) Molecular cloning and functional expression of KCNQ5, a potassium channel subunit that may contribute to neuronal M-current diversity. J. Biol. Chem. 275: 22395-400 [PMID:10787416]

368. Levite M, Cahalon L, Peretz A, Hershkoviz R, Sobko A, Ariel A, Desai R, Attali B and Lider O. (2000) Extracellular $\mathrm{K}(+)$ and opening of voltage-gated potassium channels activate $T$ cell integrin function: physical and functional association between Kv1.3 channels and beta1 integrins. J. Exp. Med. 191: 116776 [PMID:10748234]

369. Lewis A, Green K, Dawson C, Redrup L, Huynh KD, Lee JT, Hemberger M and Reik W. (2006) Epigenetic dynamics of the Kcnq1 imprinted domain in the early embryo. Development 133: 4203-10 [PMID:17021040]

370. Lewis RS and Cahalan MD. (1988) Subset-specific expression of potassium channels in developing murine T lymphocytes. Science 239: 771-5 [PMID:2448877]

371. Li GR, Feng J, Yue L, Carrier M and Nattel S. (1996) Evidence for two components of delayed rectifier K+ current in human ventricular myocytes. Circ. Res. 78: 689-96 [PMID:8635226]

372. Li HL, Qu YJ, Lu YC, Bondarenko VE, Wang S, Skerrett IM and Morales MJ. (2006) DPP10 is an inactivation modulatory protein of Kv4.3 and Kv1.4. Am. J. Physiol., Cell Physiol.291: C966-76 [PMID:16738002]

373. Li Q, Rottländer M, Xu M, Christoffersen CT, Frederiksen K, Wang MW and Jensen HS. (2011) Identification of novel KCNQ4 openers by a high-throughput fluorescence-based thallium flux assay. Anal. Biochem. 418: 66-72 [PMID:21782781]

374. Li XN, Herrington J, Petrov A, Ge L, Eiermann G, Xiong Y, Jensen MV, Hohmeier HE, Newgard CB and Garcia ML et al.. (2013) The role of voltage-gated potassium channels Kv2.1 and Kv2.2 in the regulation of insulin and somatostatin release from pancreatic islets. J. Pharmacol. Exp. Ther. 344: 407-16 [PMID:23161216]

375. Li Y, Chen L, Kass RS and Dessauer CW. (2012) The A-kinase anchoring protein Yotiao facilitates complex formation between adenylyl cyclase type 9 and the IKs potassium channel in heart. J. Biol. Chem. 287: 29815-24 [PMID:22778270]

376. Li Y, Gamper N, Hilgemann DW and Shapiro MS. (2005) Regulation of Kv7 (KCNQ) K+ channel open 
probability by phosphatidylinositol 4,5-bisphosphate. J. Neurosci. 25: 9825-35 [PMID:16251430]

377. Li Y, Gamper N and Shapiro MS. (2004) Single-channel analysis of KCNQ K+ channels reveals the mechanism of augmentation by a cysteine-modifying reagent. J. Neurosci. 24: 5079-90 [PMID:15175377]

378. Li Y, Um SY and McDonald TV. (2006) Voltage-gated potassium channels: regulation by accessory subunits. Neuroscientist 12: 199-210 [PMID:16684966]

379. Li Y, Wang P, Xu J and Desir GV. (2006) Voltage-gated potassium channel Kv1.3 regulates GLUT4 trafficking to the plasma membrane via a Ca2+-dependent mechanism. Am. J. Physiol., Cell Physiol. 290: C345-51 [PMID:16403947]

380. Liang CZ, Guo QK, Hao ZY, Yang S, Wang DB, Wu LX, Liu C, Wang KX and Zhang XJ. (2006) K channel expression in prostate epithelium and its implications in men with chronic prostatitis. BJU Int. 97: 190-2 [PMID:16336354]

381. Liao Z, Yuan C, Deng M, Li J, Chen J, Yang Y, Hu W and Liang S. (2006) Solution structure and functional characterization of jingzhaotoxin-XI: a novel gating modifier of both potassium and sodium channels. Biochemistry 45: 15591-600 [PMID:17176080]

382. Liao Z, Yuan C, Peng K, Xiao Y and Liang S. (2007) Solution structure of Jingzhaotoxin-III, a peptide toxin inhibiting both Nav1.5 and Kv2.1 channels. Toxicon 50: 135-43 [PMID:17481690]

383. Lien CC, Martina M, Schultz JH, Ehmke H and Jonas P. (2002) Gating, modulation and subunit composition of voltage-gated $\mathrm{K}(+)$ channels in dendritic inhibitory interneurones of rat hippocampus. J. Physiol. (Lond.) 538: 405-19 [PMID:11790809]

384. Lin YL, Chen CY, Cheng CP and Chang LS. (2004) Protein-protein interactions of KChIP proteins and Kv4.2. Biochem. Biophys. Res. Commun. 321: 606-10 [PMID:15358149]

385. Liu J, Deng JX, Pan BX and Huang QB. (2006) [KCNE2 modulates the function of Kv4.3 channel]Nan Fang Yi Ke Da Xue Xue Bao 26: 1754-6 [PMID:17259113]

386. Liu PW and Bean BP. (2014) Kv2 channel regulation of action potential repolarization and firing patterns in superior cervical ganglion neurons and hippocampal CA1 pyramidal neurons. J. Neurosci. 34: 4991-5002 [PMID:24695716]

387. Liu QH, Fleischmann BK, Hondowicz B, Maier CC, Turka LA, Yui K, Kotlikoff MI, Wells AD and Freedman BD. (2002) Modulation of Kv channel expression and function by TCR and costimulatory signals during peripheral CD4(+) lymphocyte differentiation. J. Exp. Med. 196: 897-909 [PMID:12370252]

388. Liu SJ and Kaczmarek LK. (1998) The expression of two splice variants of the Kv3.1 potassium channel gene is regulated by different signaling pathways. J. Neurosci. 18: 2881-90 [PMID:9526005]

389. Lock LF, Gilbert DJ, Street VA, Migeon MB, Jenkins NA, Copeland NG and Tempel BL. (1994) Voltagegated potassium channel genes are clustered in paralogous regions of the mouse genome. Genomics 20: 354-62 [PMID:8034307]

390. London B, Baker LC, Petkova-Kirova P, Nerbonne JM, Choi BR and Salama G. (2007) Dispersion of repolarization and refractoriness are determinants of arrhythmia phenotype in transgenic mice with long QT. J. Physiol. (Lond.) 578: 115-29 [PMID:17110412]

391. London B, Trudeau MC, Newton KP, Beyer AK, Copeland NG, Gilbert DJ, Jenkins NA, Satler CA and Robertson GA. (1997) Two isoforms of the mouse ether-a-go-go-related gene coassemble to form channels with properties similar to the rapidly activating component of the cardiac delayed rectifier $\mathrm{K}+$ current. Circ. Res. 81: 870-8 [PMID:9351462]

392. Lopatin AN and Nichols CG. (1994) Internal Na+ and Mg2+ blockade of DRK1 (Kv2.1) potassium channels expressed in Xenopus oocytes. Inward rectification of a delayed rectifier. J. Gen. Physiol. 103: 203-16 [PMID:8189205]

393. Loussouarn G, Park KH, Bellocq C, Baró I, Charpentier F and Escande D. (2003) Phosphatidylinositol-4,5bisphosphate, PIP2, controls KCNQ1/KCNE1 voltage-gated potassium channels: a functional homology between voltage-gated and inward rectifier K+ channels. EMBO J. 22: 5412-21 [PMID:14532114]

394. Ludwig J, Owen D and Pongs O. (1997) Carboxy-terminal domain mediates assembly of the voltage-gated rat ether-à-go-go potassium channel. EMBO J. 16: 6337-45 [PMID:9400421]

395. Ludwig J, Terlau H, Wunder F, Brüggemann A, Pardo LA, Marquardt A, Stühmer W and Pongs O. (1994) 
Functional expression of a rat homologue of the voltage gated either á go-go potassium channel reveals differences in selectivity and activation kinetics between the Drosophila channel and its mammalian counterpart. EMBO J. 13: 4451-8 [PMID:7925287]

396. Ludwig J, Weseloh R, Karschin C, Liu Q, Netzer R, Engeland B, Stansfeld C and Pongs O. (2000) Cloning and functional expression of rat eag2, a new member of the ether-à-go-go family of potassium channels and comparison of its distribution with that of eag1. Mol. Cell. Neurosci. 16: 59-70 [PMID:10882483]

397. Lundby A and Olesen SP. (2006) KCNE3 is an inhibitory subunit of the Kv4.3 potassium channel. Biochem. Biophys. Res. Commun. 346: 958-67 [PMID:16782062]

398. Luneau C, Wiedmann R, Smith JS and Williams JB. (1991) Shaw-like rat brain potassium channel cDNA's with divergent 3' ends. FEBS Lett. 288: 163-7 [PMID:1879548]

399. Luneau CJ, Williams JB, Marshall J, Levitan ES, Oliva C, Smith JS, Antanavage J, Folander K, Stein RB and Swanson $R$ et al.. (1991) Alternative splicing contributes to K+ channel diversity in the mammalian central nervous system. Proc. Natl. Acad. Sci. U.S.A. 88: 3932-6 [PMID:2023941]

400. Macaulay EC, Roberts HE, Cheng X, Jeffs AR, Baguley BC and Morison IM. (2014) Retrotransposon hypomethylation in melanoma and expression of a placenta-specific gene. PLOS ONE 9: e95840 [PMID:24759919]

401. MacDonald PE, Ha XF, Wang J, Smukler SR, Sun AM, Gaisano HY, Salapatek AM, Backx PH and Wheeler MB. (2001) Members of the Kv1 and Kv2 voltage-dependent $\mathrm{K}(+)$ channel families regulate insulin secretion. Mol. Endocrinol. 15: 1423-35 [PMID:11463864]

402. Mackenzie AB, Chirakkal $H$ and North RA. (2003) Kv1.3 potassium channels in human alveolar macrophages. Am. J. Physiol. Lung Cell Mol. Physiol. 285: L862-8 [PMID:12909584]

403. Madeja M, Müller V, Musshoff $U$ and Speckmann EJ. (2000) Sensitivity of native and cloned hippocampal delayed-rectifier potassium channels to verapamil. Neuropharmacology 39: 202-10 [PMID:10670415]

404. Main MJ, Cryan JE, Dupere JR, Cox B, Clare JJ and Burbidge SA. (2000) Modulation of KCNQ2/3 potassium channels by the novel anticonvulsant retigabine. Mol. Pharmacol. 58: 253-62 [PMID:10908292]

405. Malayev AA, Nelson DJ and Philipson LH. (1995) Mechanism of clofilium block of the human Kv1.5 delayed rectifier potassium channel. Mol. Pharmacol. 47: 198-205 [PMID:7838129]

406. Malin SA and Nerbonne JM. (2002) Delayed rectifier K+ currents, IK, are encoded by Kv2 alpha-subunits and regulate tonic firing in mammalian sympathetic neurons. J. Neurosci. 22: 10094-105 [PMID:12451110]

407. Malysz J, Farrugia G, Ou Y, Szurszewski JH, Nehra A and Gibbons SJ. (2002) The Kv2.2 alpha subunit contributes to delayed rectifier $\mathrm{K}(+)$ currents in myocytes from rabbit corpus cavernosum. J. Androl. 23: 899-910 [PMID:12399537]

408. Mandikian D, Bocksteins E, Parajuli LK, Bishop HI, Cerda O, Shigemoto R and Trimmer JS. (2014) Cell type-specific spatial and functional coupling between mammalian brain Kv2.1 K+ channels and ryanodine receptors. J. Comp. Neurol. 522: 3555-74 [PMID:24962901]

409. Manganas LN, Akhtar S, Antonucci DE, Campomanes CR, Dolly JO and Trimmer JS. (2001) Episodic ataxia type-1 mutations in the Kv1.1 potassium channel display distinct folding and intracellular trafficking properties. J. Biol. Chem. 276: 49427-34 [PMID:11679591]

410. Mareschi K, Novara M, Rustichelli D, Ferrero I, Guido D, Carbone E, Medico E, Madon E, Vercelli A and Fagioli F. (2006) Neural differentiation of human mesenchymal stem cells: Evidence for expression of neural markers and eag K+ channel types. Exp. Hematol. 34: 1563-72 [PMID:17046576]

411. Marionneau C, Carrasquillo Y, Norris AJ, Townsend RR, Isom LL, Link AJ and Nerbonne JM. (2012) The sodium channel accessory subunit Nav $\beta 1$ regulates neuronal excitability through modulation of repolarizing voltage-gated K+ channels. J. Neurosci. 32: 5716-27 [PMID:22539834]

412. Marionneau C, LeDuc RD, Rohrs HW, Link AJ, Townsend RR and Nerbonne JM. (2009) Proteomic analyses of native brain K(V)4.2 channel complexes. Channels (Austin) 3: 284-94 [PMID:19713751]

413. Martens JR, Sakamoto N, Sullivan SA, Grobaski TD and Tamkun MM. (2001) Isoform-specific localization of voltage-gated $\mathrm{K}+$ channels to distinct lipid raft populations. Targeting of Kv1.5 to caveolae. J. Biol.

Chem. 276: 8409-14 [PMID:11115511]

414. Martire M, Castaldo P, D'Amico M, Preziosi P, Annunziato L and Taglialatela M. (2004) M channels 
containing KCNQ2 subunits modulate norepinephrine, aspartate, and GABA release from hippocampal nerve terminals. J. Neurosci. 24: 592-7 [PMID:14736843]

415. Maruoka ND, Steele DF, Au BP, Dan P, Zhang X, Moore ED and Fedida D. (2000) alpha-actinin-2 couples to cardiac Kv1.5 channels, regulating current density and channel localization in HEK cells. FEBS Lett. 473: 188-94 [PMID:10812072]

416. Maruyama Y. (1987) A patch-clamp study of mammalian platelets and their voltage-gated potassium current. J. Physiol. (Lond.) 391: 467-85 [PMID:2451010]

417. Marx SO, Kurokawa J, Reiken S, Motoike H, D'Armiento J, Marks AR and Kass RS. (2002) Requirement of a macromolecular signaling complex for beta adrenergic receptor modulation of the KCNQ1-KCNE1 potassium channel. Science 295: 496-9 [PMID:11799244]

418. Massengill JL, Smith MA, Son DI and O'Dowd DK. (1997) Differential expression of K4-AP currents and Kv3.1 potassium channel transcripts in cortical neurons that develop distinct firing phenotypes. J. Neurosci. 17: 3136-47 [PMID:9096148]

419. Matsubara H, Liman ER, Hess $P$ and Koren G. (1991) Pretranslational mechanisms determine the type of potassium channels expressed in the rat skeletal and cardiac muscles. J. Biol. Chem. 266: 13324-8 [PMID:1712780]

420. Matsubara H, Suzuki J and Inada M. (1993) Shaker-related potassium channel, Kv1.4, mRNA regulation in cultured rat heart myocytes and differential expression of Kv1.4 and Kv1.5 genes in myocardial development and hypertrophy. J. Clin. Invest. 92: 1659-66 [PMID:7691883]

421. Matteson DR and Deutsch C. (1984) K channels in T lymphocytes: a patch clamp study using monoclonal antibody adhesion. Nature 307: 468-71 [PMID:6320008]

422. Mattmann ME, Yu H, Lin Z, Xu K, Huang X, Long S, Wu M, McManus OB, Engers DW and Le UMet al.. (2012) Identification of (R)-N-(4-(4-methoxyphenyl)thiazol-2-yl)-1-tosylpiperidine-2-carboxamide, ML277, as a novel, potent and selective K(v)7.1 (KCNQ1) potassium channel activator. Bioorg. Med. Chem. Lett. 22: 5936-41 [PMID:22910039]

423. Matus-Leibovitch N, Vogel Z, Ezra-Macabee V, Etkin S, Nevo I and Attali B. (1996) Chronic morphine administration enhances the expression of $\mathrm{Kv} 1.5$ and $\mathrm{Kv} 1.6$ voltage-gated $\mathrm{K}+$ channels in rat spinal cord. Brain Res. Mol. Brain Res. 40: 261-70 [PMID:8872310]

424. Mazzanti CM, Bergen A, Enoch MA, Michelini S and Goldman D. (1996) Identification of a Ser857-Asn857 substitution in DRK1 (KCNB1), population frequencies and lack of association to the low voltage alpha EEG trait. Hum. Genet. 98: 134-7 [PMID:8698327]

425. McCord MC and Aizenman E. (2013) Convergent $\mathrm{Ca} 2+$ and $\mathrm{Zn} 2+$ signaling regulates apoptotic $\mathrm{Kv} 2.1 \mathrm{~K}+$ currents. Proc. Natl. Acad. Sci. U.S.A. 110: 13988-93 [PMID:23918396]

426. McCormack K, McCormack T, Tanouye M, Rudy B and Stühmer W. (1995) Alternative splicing of the human Shaker $\mathrm{K}+$ channel beta 1 gene and functional expression of the beta 2 gene product. FEBS Lett. 370: 32-6 [PMID:7649300]

427. McCormack T, Rudy B and Seldin MF. (1999) Chromosomal mapping of the potassium channel genes Kcnq2 and Kcnq3 in mouse. Genomics 56: 360-1 [PMID:10087209]

428. McCormack T, Vega-Saenz de Miera EC and Rudy B. (1990) Molecular cloning of a member of a third class of Shaker-family K+ channel genes in mammals. Proc. Natl. Acad. Sci. U.S.A. 87: 5227-31 [PMID:2367536]

429. McDonald AJ and Mascagni F. (2006) Differential expression of Kv3.1b and Kv3.2 potassium channel subunits in interneurons of the basolateral amygdala. Neuroscience 138: 537-47 [PMID:16413129]

430. McDonald TV, Yu Z, Ming Z, Palma E, Meyers MB, Wang KW, Goldstein SA and Fishman GI. (1997) A minK-HERG complex regulates the cardiac potassium current I(Kr). Nature 388: 289-92 [PMID:9230439]

431. McKay BE and Turner RW. (2004) Kv3 K+ channels enable burst output in rat cerebellar Purkinje cells. Eur. J. Neurosci. 20: 729-39 [PMID:15255983]

432. McKay MC and Worley JF. (2001) Linoleic acid both enhances activation and blocks Kv1.5 and Kv2.1 channels by two separate mechanisms. Am. J. Physiol., Cell Physiol. 281: C1277-84 [PMID:11546665]

433. McKinnon D. (1989) Isolation of a cDNA clone coding for a putative second potassium channel indicates 
the existence of a gene family. J. Biol. Chem. 264: 8230-6 [PMID:2722779]

434. Melis R, Stauffer D, Zhao X, Zhu XL, Albrecht B, Pongs O, Brothman A and Leppert M. (1995) Physical and genetic localization of a Shab subfamily potassium channel (KCNB1) gene to chromosomal region 20q13.2. Genomics 25: 285-7 [PMID:7774931]

435. Mello de Queiroz F, Suarez-Kurtz G, Stühmer W and Pardo LA. (2006) Ether à go-go potassium channel expression in soft tissue sarcoma patients. Mol. Cancer 5: 42 [PMID:17022811]

436. Mencía A, González-Nieto D, Modamio-Høybjør S, Etxeberría A, Aránguez G, Salvador N, Del Castillo I, Villarroel A, Moreno F and Barrio L et al.. (2008) A novel KCNQ4 pore-region mutation (p.G296S) causes deafness by impairing cell-surface channel expression. Hum. Genet. 123: 41-53 [PMID:18030493]

437. Meyer R and Heinemann SH. (1998) Characterization of an eag-like potassium channel in human neuroblastoma cells. J. Physiol. (Lond.) 508 ( Pt 1): 49-56 [PMID:9490815]

438. Meyer R, Schönherr R, Gavrilova-Ruch O, Wohlrab W and Heinemann SH. (1999) Identification of ether à go-go and calcium-activated potassium channels in human melanoma cells. J. Membr. Biol. 171: 107-15 [PMID:10489423]

439. Michelakis ED, McMurtry MS, Wu XC, Dyck JR, Moudgil R, Hopkins TA, Lopaschuk GD, Puttagunta L, Waite R and Archer SL. (2002) Dichloroacetate, a metabolic modulator, prevents and reverses chronic hypoxic pulmonary hypertension in rats: role of increased expression and activity of voltage-gated potassium channels. Circulation 105: 244-50 [PMID:11790708]

440. Michne WF, Guiles JW, Treasurywala AM, Castonguay LA, Weigelt CA, Oconnor B, Volberg WA, Grant AM, Chadwick CC and Krafte DS et al.. (1995) Novel inhibitors of potassium ion channels on human T lymphocytes. J. Med. Chem. 38: 1877-83 [PMID:7540207]

441. Middleton RE, Sanchez M, Linde AR, Bugianesi RM, Dai G, Felix JP, Koprak SL, Staruch MJ, Bruguera M and Cox R et al.. (2003) Substitution of a single residue in Stichodactyla helianthus peptide, ShK-Dap22, reveals a novel pharmacological profile. Biochemistry 42: 13698-707 [PMID:14622016]

442. Migeon MB, Street VA, Demas VP and Tempel BL. (1992) Cloning, sequence and chromosomal localization of MK6, a murine potassium channel gene. Epilepsy Res. Suppl. 9: 173-80; discussion 180-1 [PMID:1285906]

443. Mikami M, Yasuda T, Terao A, Nakamura M, Ueno S, Tanabe H, Tanaka T, Onuma T, Goto Y, Kaneko S and Sano A. (1999) Localization of a gene for benign adult familial myoclonic epilepsy to chromosome 8q23.3-q24.1. Am. J. Hum. Genet.65: 745-51 [PMID:10441581]

444. Misonou H, Menegola M, Mohapatra DP, Guy LK, Park KS and Trimmer JS. (2006) Bidirectional activitydependent regulation of neuronal ion channel phosphorylation. J. Neurosci. 26: 13505-14 [PMID:17192433]

445. Mitcheson J, Perry M, Stansfeld P, Sanguinetti MC, Witchel H and Hancox J. (2005) Structural determinants for high-affinity block of hERG potassium channels. Novartis Found. Symp. 266: 136-50; discussion 150-8 [PMID:16050266]

446. Mitcheson JS, Chen J and Sanguinetti MC. (2000) Trapping of a methanesulfonanilide by closure of the HERG potassium channel activation gate. J. Gen. Physiol. 115: 229-40 [PMID:10694252]

447. Miyake A, Mochizuki S, Yokoi H, Kohda M and Furuichi K. (1999) New ether-à-go-go K(+) channel family members localized in human telencephalon. J. Biol. Chem. 274: 25018-25 [PMID:10455180]

448. Miyake A, Takahashi S, Nakamura Y, Inamura K, Matsumoto S, Mochizuki S and Katou M. (2009) Disruption of the ether-a-go-go $\mathrm{K}+$ channel gene $\mathrm{BEC} 1 / \mathrm{KCNH} 3$ enhances cognitive function. J. Neurosci. 29: 14637-45 [PMID:19923296]

449. Moreno H, Kentros C, Bueno E, Weiser M, Hernandez A, Vega-Saenz de Miera E, Ponce A, Thornhill W and Rudy B. (1995) Thalamocortical projections have a K+ channel that is phosphorylated and modulated by cAMP-dependent protein kinase. J. Neurosci. 15: 5486-501 [PMID:7643197]

450. Moreno H, Vega-Saenz de Miera E, Nadal MS, Amarillo Y and Rudy B. (2001) Modulation of Kv3 potassium channels expressed in $\mathrm{CHO}$ cells by a nitric oxide-activated phosphatase. J. Physiol. (Lond.) 530: 345-58 [PMID:11281123]

451. Mori S, Nakamura M, Yasuda T, Ueno S, Kaneko S and Sano A. (2011) Remapping and mutation analysis 
of benign adult familial myoclonic epilepsy in a Japanese pedigree. J. Hum. Genet. 56: 742-7

[PMID:21850007]

452. Mouhat $\mathrm{S}$, Visan $\mathrm{V}$, Ananthakrishnan $\mathrm{S}$, Wulff $\mathrm{H}$, Andreotti $\mathrm{N}$, Grissmer $\mathrm{S}$, Darbon $\mathrm{H}$, De Waard $\mathrm{M}$ and Sabatier JM. (2005) K+ channel types targeted by synthetic OSK1, a toxin from Orthochirus scrobiculosus scorpion venom. Biochem. J. 385: 95-104 [PMID:15588251]

453. Muona M, Berkovic SF, Dibbens LM, Oliver KL, Maljevic S, Bayly MA, Joensuu T, Canafoglia L, Franceschetti $S$ and Michelucci R et al.. (2015) A recurrent de novo mutation in KCNC1 causes progressive myoclonus epilepsy. Nat. Genet. 47: 39-46 [PMID:25401298]

454. Murakoshi $\mathrm{H}$ and Trimmer JS. (1999) Identification of the Kv2.1 $\mathrm{K}+$ channel as a major component of the delayed rectifier K+ current in rat hippocampal neurons. J. Neurosci. 19: 1728-35 [PMID:10024359]

455. Murata M, Buckett PD, Zhou J, Brunner M, Folco E and Koren G. (2001) SAP97 interacts with Kv1.5 in heterologous expression systems. Am. J. Physiol. Heart Circ. Physiol. 281: H2575-84 [PMID:11709425]

456. Mühlbauer E, Bazwinsky I, Wolgast S, Klemenz A and Peschke E. (2007) Circadian changes of ether-ago-go-related-gene (Erg) potassium channel transcripts in the rat pancreas and beta-cell. Cell. Mol. Life Sci. 64: 768-80 [PMID:17322986]

457. Müller R, Thiele J, Klages U and Lingens F. (1984) Incorporation of [18O]water into 4-hydroxybenzoic acid in the reaction of 4-chlorobenzoate dehalogenase from pseudomonas spec. CBS 3. Biochem. Biophys. Res. Commun. 124: 178-82 [PMID:6497878]

458. Nadal MS, Ozaita A, Amarillo Y, Vega-Saenz de Miera E, Ma Y, Mo W, Goldberg EM, Misumi Y, Ikehara Y and Neubert TA et al.. (2003) The CD26-related dipeptidyl aminopeptidase-like protein DPPX is a critical component of neuronal A-type K+ channels. Neuron 37: 449-61 [PMID:12575952]

459. Nakajima T, Hayashi K, Viswanathan PC, Kim MY, Anghelescu M, Barksdale KA, Shuai W, Balser JR and Kupershmidt S. (2007) HERG is protected from pharmacological block by alpha-1,2-glucosyltransferase function. J. Biol. Chem. 282: 5506-13 [PMID:17189275]

460. Nakajo K and Kubo Y. (2014) Steric hindrance between S4 and S5 of the KCNQ1/KCNE1 channel hampers pore opening. Nat Commun 5: 4100 [PMID:24920132]

461. Nakamura TY, Nandi S, Pountney DJ, Artman M, Rudy B and Coetzee WA. (2001) Different effects of the $\mathrm{Ca}(2+)$-binding protein, KChIP1, on two Kv4 subfamily members, Kv4.1 and Kv4.2. FEBS Lett. 499: 205-9 [PMID:11423117]

462. Nakamura TY, Sturm E, Pountney DJ, Orenzoff B, Artman M and Coetzee WA. (2003) Developmental expression of NCS-1 (frequenin), a regulator of Kv4 K+ channels, in mouse heart. Pediatr. Res. 53: 554-7 [PMID:12612193]

463. Nelson DJ, Jow B and Jow F. (1990) Whole-cell currents in macrophages: I. Human monocyte-derived macrophages. J. Membr. Biol. 117: 29-44 [PMID:2402007]

464. Nerbonne JM. (2000) Molecular basis of functional voltage-gated $\mathrm{K}+$ channel diversity in the mammalian myocardium. J. Physiol. (Lond.) 525 Pt 2: 285-98 [PMID:10835033]

465. Neyroud N, Tesson F, Denjoy I, Leibovici M, Donger C, Barhanin J, Fauré S, Gary F, Coumel P and Petit $C$ et al.. (1997) A novel mutation in the potassium channel gene KVLQT1 causes the Jervell and LangeNielsen cardioauditory syndrome. Nat. Genet. 15: 186-9 [PMID:9020846]

466. Ng FL, Davis AJ, Jepps TA, Harhun MI, Yeung SY, Wan A, Reddy M, Melville D, Nardi A and Khong TKet al.. (2011) Expression and function of the K+ channel KCNQ genes in human arteries Br. J. Pharmacol. 162: $42-53$ [PMID:20840535]

467. Nguyen A, Kath JC, Hanson DC, Biggers MS, Canniff PC, Donovan CB, Mather RJ, Bruns MJ, Rauer H and Aiyar J et al.. (1996) Novel nonpeptide agents potently block the C-type inactivated conformation of Kv1.3 and suppress T cell activation. Mol. Pharmacol. 50: 1672-9 [PMID:8967992]

468. Ninkovic M, Mitkovski M, Kohl T, Stühmer W and Pardo LA. (2012) Physical and functional interaction of KV10.1 with Rabaptin-5 impacts ion channel trafficking. FEBS Lett. 586: 3077-84 [PMID:22841712]

469. Noma K, Kimura K, Minatohara K, Nakashima H, Nagao Y, Mizoguchi A and Fujiyoshi Y. (2009) Triple Nglycosylation in the long S5-P loop regulates the activation and trafficking of the Kv12.2 potassium channel. J. Biol. Chem. 284: 33139-50 [PMID:19808681] 
470. Norris AJ and Nerbonne JM. (2010) Molecular dissection of $\mathrm{I}(\mathrm{A})$ in cortical pyramidal neurons reveals three distinct components encoded by Kv4.2, Kv4.3, and Kv1.4 alpha-subunits. J. Neurosci. 30: 5092-101 [PMID:20371829]

471. O'Connell DJ, Bauer MC, O'Brien J, Johnson WM, Divizio CA, O'Kane SL, Berggård T, Merino A, Akerfeldt KS and Linse $S$ et al.. (2010) Integrated protein array screening and high throughput validation of 70 novel neural calmodulin-binding proteins. Mol. Cell Proteomics 9: 1118-32 [PMID:20068228]

472. O'Neill PM, Park BK, Shone AE, Maggs JL, Roberts P, Stocks PA, Biagini GA, Bray PG, Gibbons P and Berry N et al.. (2009) Candidate selection and preclinical evaluation of N-tert-butyl isoquine (GSK369796), an affordable and effective 4-aminoquinoline antimalarial for the 21st century. J. Med. Chem. 52: 1408-15 [PMID:19222165]

473. Occhiodoro T, Bernheim L, Liu JH, Bijlenga P, Sinnreich M, Bader CR and Fischer-Lougheed J. (1998) Cloning of a human ether-a-go-go potassium channel expressed in myoblasts at the onset of fusion. FEBS Lett. 434: 177-82 [PMID:9738473]

474. Ogawa Y, Oses-Prieto J, Kim MY, Horresh I, Peles E, Burlingame AL, Trimmer JS, Meijer D and Rasband MN. (2010) ADAM22, a Kv1 channel-interacting protein, recruits membrane-associated guanylate kinases to juxtaparanodes of myelinated axons. J. Neurosci. 30: 1038-48 [PMID:20089912]

475. Ohya S, Sergeant GP, Greenwood IA and Horowitz B. (2003) Molecular variants of KCNQ channels expressed in murine portal vein myocytes: a role in delayed rectifier current. Circ. Res. 92: 1016-23 [PMID:12690036]

476. Ohya S, Tanaka M, Oku T, Asai Y, Watanabe M, Giles WR and Imaizumi Y. (1997) Molecular cloning and tissue distribution of an alternatively spliced variant of an A-type K+ channel alpha-subunit, Kv4.3 in the rat. FEBS Lett. 420: 47-53 [PMID:9450548]

477. Ohya S, Tanaka M, Oku T, Furuyama T, Mori N, Giles WR, Watanabe M and Imaizumi Y. (2001) Regional expression of the splice variants of Kv4.3 in rat brain and effects of C-terminus deletion on expressed $\mathrm{K}+$ currents. Life Sci. 68: 1703-16 [PMID:11270617]

478. Olesen MS, Refsgaard L, Holst AG, Larsen AP, Grubb S, Haunsø S, Svendsen JH, Olesen SP, Schmitt N and Calloe K. (2013) A novel KCND3 gain-of-function mutation associated with early-onset of persistent lone atrial fibrillation. Cardiovasc. Res. 98: 488-95 [PMID:23400760]

479. Olson TM, Alekseev AE, Liu XK, Park S, Zingman LV, Bienengraeber M, Sattiraju S, Ballew JD, Jahangir A and Terzic A. (2006) Kv1.5 channelopathy due to KCNA5 loss-of-function mutation causes human atrial fibrillation. Hum. Mol. Genet. 15: 2185-91 [PMID:16772329]

480. Ordög B, Brutyó E, Puskás LG, Papp JG, Varró A, Szabad J and Boldogkoi Z. (2006) Gene expression profiling of human cardiac potassium and sodium channels. Int. J. Cardiol. 111: 386-93 [PMID:16257073]

481. Orias M, Bray-Ward P, Curran ME, Keating MT and Desir GV. (1997) Genomic localization of the human gene for KCNA10, a cGMP-activated K channel. Genomics 42: 33-7 [PMID:9177773]

482. Osteen JD, Barro-Soria R, Robey S, Sampson KJ, Kass RS and Larsson HP. (2012) Allosteric gating mechanism underlies the flexible gating of KCNQ1 potassium channels. Proc. Natl. Acad. Sci. U.S.A.109: 7103-8 [PMID:22509038]

483. Osteen JD, Gonzalez C, Sampson KJ, lyer V, Rebolledo S, Larsson HP and Kass RS. (2010) KCNE1 alters the voltage sensor movements necessary to open the KCNQ1 channel gate. Proc. Natl. Acad. Sci. U.S.A. 107: 22710-5 [PMID:21149716]

484. Ota M, Ito T, Umemura T, Katsuyama Y, Yoshizawa K, Hamano H and Kawa S. (2011) Polymorphism in the KCNA3 gene is associated with susceptibility to autoimmune pancreatitis in the Japanese population. Dis. Markers 31: 223-9 [PMID:22045429]

485. Ottschytsch N, Raes A, Van Hoorick D and Snyders DJ. (2002) Obligatory heterotetramerization of three previously uncharacterized $\mathrm{Kv}$ channel alpha-subunits identified in the human genome. Proc. Natl. Acad. Sci. U.S.A. 99: 7986-91 [PMID:12060745]

486. Ouadid-Ahidouch H, Le Bourhis X, Roudbaraki M, Toillon RA, Delcourt P and Prevarskaya N. (2001) Changes in the $\mathrm{K}+$ current-density of MCF-7 cells during progression through the cell cycle: possible involvement of a h-ether.a-gogo K+ channel. Recept. Channels 7: 345-56 [PMID:11697078] 
487. Ousingsawat J, Spitzner M, Puntheeranurak S, Terracciano L, Tornillo L, Bubendorf L, Kunzelmann K and Schreiber R. (2007) Expression of voltage-gated potassium channels in human and mouse colonic carcinoma. Clin. Cancer Res. 13: 824-31 [PMID:17289873]

488. Padilla K, Wickenden AD, Gerlach AC and McCormack K. (2009) The KCNQ2/3 selective channel opener ICA-27243 binds to a novel voltage-sensor domain site. Neurosci. Lett. 465: 138-42 [PMID:19733209]

489. Pagon RA, Adam MP, Ardinger HH, Wallace SE, Amemiya A, Bean LJH, Bird TD, Dolan CR, Fong CT and Smith RJH et al.. (1993) Spinocerebellar Ataxia Type 13.GeneReviews(B) [PMID:20301404]

490. Pak MD, Baker K, Covarrubias M, Butler A, Ratcliffe A and Salkoff L. (1991) mShal, a subfamily of A-type K+ channel cloned from mammalian brain. Proc. Natl. Acad. Sci. U.S.A. 88: 4386-90 [PMID:2034678]

491. Pal S, Hartnett KA, Nerbonne JM, Levitan ES and Aizenman E. (2003) Mediation of neuronal apoptosis by Kv2.1-encoded potassium channels. J. Neurosci. 23: 4798-802 [PMID:12832499]

492. Pan $Y, X u X$, Tong $X$ and Wang $X$. (2004) Messenger RNA and protein expression analysis of voltagegated potassium channels in the brain of Abeta(25-35)-treated rats. J. Neurosci. Res. 77: 94-9 [PMID:15197742]

493. Pan Z, Kao T, Horvath Z, Lemos J, Sul JY, Cranstoun SD, Bennett V, Scherer SS and Cooper EC. (2006) A common ankyrin-G-based mechanism retains $\mathrm{KCNQ}$ and $\mathrm{NaV}$ channels at electrically active domains of the axon. J. Neurosci. 26: 2599-613 [PMID:16525039]

494. Panaghie $G$ and Abbott GW. (2007) The role of $S 4$ charges in voltage-dependent and voltage-independent KCNQ1 potassium channel complexes. J. Gen. Physiol. 129: 121-33 [PMID:17227916]

495. Pannaccione A, Boscia F, Scorziello A, Adornetto A, Castaldo P, Sirabella R, Taglialatela M, Di Renzo GF and Annunziato L. (2007) Up-regulation and increased activity of KV3.4 channels and their accessory subunit MinK-related peptide 2 induced by amyloid peptide are involved in apoptotic neuronal death. Mol. Pharmacol. 72: 665-73 [PMID:17495071]

496. Pardo LA, Brüggemann A, Camacho J and Stühmer W. (1998) Cell cycle-related changes in the conducting properties of r-eag K+ channels. J. Cell Biol. 143: 767-75 [PMID:9813096]

497. Pardo LA, del Camino D, Sánchez A, Alves F, Brüggemann A, Beckh S and Stühmer W. (1999) Oncogenic potential of EAG K(+) channels. EMBO J. 18: 5540-7 [PMID:10523298]

498. Pardo-Lopez L, Zhang M, Liu J, Jiang M, Possani LD and Tseng GN. (2002) Mapping the binding site of a human ether-a-go-go-related gene-specific peptide toxin (ErgTx) to the channel's outer vestibule. J. Biol. Chem. 277: 16403-11 [PMID:11864985]

499. Patel AJ, Lazdunski M and Honoré E. (1999) Kv2.1/Kv9.3, an ATP-dependent delayed-rectifier K+ channel in pulmonary artery myocytes. Ann. N. Y. Acad. Sci. 868: 438-41 [PMID:10414317]

500. Patel SP, Parai R, Parai R and Campbell DL. (2004) Regulation of Kv4.3 voltage-dependent gating kinetics by KChIP2 isoforms. J. Physiol. (Lond.) 557: 19-41 [PMID:14724186]

501. Peltola MA, Kuja-Panula J, Lauri SE, Taira T and Rauvala H. (2011) AMIGO is an auxiliary subunit of the Kv2.1 potassium channel. EMBO Rep. 12: 1293-9 [PMID:22056818]

502. Pennington MW, Byrnes ME, Zaydenberg I, Khaytin I, de Chastonay J, Krafte DS, Hill R, Mahnir VM, Volberg WA and Gorczyca W. (1995) Chemical synthesis and characterization of ShK toxin: a potent potassium channel inhibitor from a sea anemone. Int. J. Pept. Protein Res. 46: 354-8 [PMID:8567178]

503. Pereira LE, Villinger $F$, Wulff $H$, Sankaranarayanan A, Raman $G$ and Ansari AA. (2007) Pharmacokinetics, toxicity, and functional studies of the selective Kv1.3 channel blocker 5-(4-phenoxybutoxy)psoralen in rhesus macaques. Exp. Biol. Med. (Maywood) 232: 1338-54 [PMID:17959847]

504. Peretz A, Degani N, Nachman R, Uziyel Y, Gibor G, Shabat D and Attali B. (2005) Meclofenamic acid and diclofenac, novel templates of KCNQ2/Q3 potassium channel openers, depress cortical neuron activity and exhibit anticonvulsant properties. Mol. Pharmacol. 67: 1053-66 [PMID:15598972]

505. Perney TM, Marshall J, Martin KA, Hockfield S and Kaczmarek LK. (1992) Expression of the mRNAs for the Kv3.1 potassium channel gene in the adult and developing rat brain. J. Neurophysiol. 68: 756-66 [PMID:1432046]

506. Perry M, de Groot MJ, Helliwell R, Leishman D, Tristani-Firouzi M, Sanguinetti MC and Mitcheson J. (2004) Structural determinants of HERG channel block by clofilium and ibutilide. Mol. Pharmacol. 66: 240-9 
[PMID:15266014]

507. Persson AS, Klement G, Almgren M, Sahlholm K, Nilsson J, Petersson S, Arhem P, Schalling M and Lavebratt C. (2005) A truncated Kv1.1 protein in the brain of the megencephaly mouse: expression and interaction. BMC Neurosci 6: 65 [PMID:16305740]

508. Peters HC, Hu H, Pongs O, Storm JF and Isbrandt D. (2005) Conditional transgenic suppression of $M$ channels in mouse brain reveals functions in neuronal excitability, resonance and behavior. Nat. Neurosci. 8: 51-60 [PMID:15608631]

509. Petersson S, Persson AS, Johansen JE, Ingvar M, Nilsson J, Klement G, Arhem P, Schalling M and Lavebratt C. (2003) Truncation of the Shaker-like voltage-gated potassium channel, Kv1.1, causes megencephaly. Eur. J. Neurosci. 18: 3231-40 [PMID:14686897]

510. Philipson LH, Hice RE, Schaefer K, LaMendola J, Bell GI, Nelson DJ and Steiner DF. (1991) Sequence and functional expression in Xenopus oocytes of a human insulinoma and islet potassium channel. Proc. Natl. Acad. Sci. U.S.A. 88: 53-7 [PMID:1986382]

511. Philipson LH, Schaefer K, LaMendola J, Bell GI and Steiner DF. (1990) Sequence of a human fetal skeletal muscle potassium channel cDNA related to RCK4. Nucleic Acids Res. 18: 7160 [PMID:2263489]

512. Phromchotikul T, Browne DL, Curran ME, Keating MT and Litt M. (1993) Dinucleotide repeat polymorphism at the KCNA5 locus. Hum. Mol. Genet. 2: 1512 [PMID:8242092]

513. Piros $E T$, Shen $L$ and Huang $X Y$. (1999) Purification of an $E H$ domain-binding protein from rat brain that modulates the gating of the rat ether-à-go-go channel. J. Biol. Chem. 274: 33677-83 [PMID:10559257]

514. Plant LD, Boyle JP, Thomas NM, Hipkins NJ, Benedikz E, Hooper NM, Henderson Z, Vaughan PF, Peers C, Cowburn RF and Pearson HA. (2002) Presenilin-1 mutations alter K+ currents in the human neuroblastoma cell line, SH-SY5Y. Neuroreport 13: 1553-6 [PMID:12218704]

515. Plant LD, Dowdell EJ, Dementieva IS, Marks JD and Goldstein SA. (2011) SUMO modification of cell surface Kv2.1 potassium channels regulates the activity of rat hippocampal neurons. J. Gen. Physiol. 137: 441-54 [PMID:21518833]

516. Plant LD, Webster NJ, Boyle JP, Ramsden M, Freir DB, Peers C and Pearson HA. (2006) Amyloid beta peptide as a physiological modulator of neuronal 'A'-type K+ current. Neurobiol. Aging 27: 1673-83 [PMID:16271805]

517. Platoshyn O, Remillard CV, Fantozzi I, Mandegar M, Sison TT, Zhang S, Burg E and Yuan JX. (2004) Diversity of voltage-dependent $\mathrm{K}+$ channels in human pulmonary artery smooth muscle cells. Am. J. Physiol. Lung Cell Mol. Physiol. 287: L226-38 [PMID:15047570]

518. Po S, Snyders DJ, Baker R, Tamkun MM and Bennett PB. (1992) Functional expression of an inactivating potassium channel cloned from human heart. Circ. Res. 71: 732-6 [PMID:1499114]

519. Poliak S, Gollan L, Martinez R, Custer A, Einheber S, Salzer JL, Trimmer JS, Shrager P and Peles E. (1999) Caspr2, a new member of the neurexin superfamily, is localized at the juxtaparanodes of myelinated axons and associates with K+ channels. Neuron 24: 1037-47 [PMID:10624965]

520. Poling JS, Rogawski MA, Salem Jr N and Vicini S. (1996) Anandamide, an endogenous cannabinoid, inhibits Shaker-related voltage-gated K+ channels. Neuropharmacology 35: 983-91 [PMID:8938728]

521. Ponce A, Vega-Saenz de Miera E, Kentros C, Moreno H, Thornhill B and Rudy B. (1997) K+ channel subunit isoforms with divergent carboxy-terminal sequences carry distinct membrane targeting signals. $J$. Membr. Biol. 159: 149-59 [PMID:9307441]

522. Post MA, Kirsch GE and Brown AM. (1996) Kv2.1 and electrically silent Kv6.1 potassium channel subunits combine and express a novel current. FEBS Lett. 399: 177-82 [PMID:8980147]

523. Potet F, Lorinc AN, Chaigne S, Hopkins CR, Venkataraman R, Stepanovic SZ, Lewis LM, Days E, Sidorov VY and Engers DW et al.. (2012) Identification and characterization of a compound that protects cardiac tissue from human Ether-à-go-go-related gene (hERG)-related drug-induced arrhythmias. J. Biol. Chem. 287: 39613-25 [PMID:23033485]

524. Pourrier M, Herrera D, Caballero R, Schram G, Wang Z and Nattel S. (2004) The Kv4.2 N-terminal restores fast inactivation and confers KChIP2 modulatory effects on $\mathrm{N}$-terminal-deleted Kv1.4 channels. Pflugers Arch. 449: 235-47 [PMID:15452711] 
525. Prole DL and Marrion NV. (2004) lonic permeation and conduction properties of neuronal KCNQ2/KCNQ3 potassium channels. Biophys. J. 86: 1454-69 [PMID:14990473]

526. Pulst SM and Otis TS. (2012) Repolarization matters: mutations in the Kv4.3 potassium channel cause SCA19/22. Ann. Neurol. 72: 829-31 [PMID:23280833]

527. Punke MA and Friederich P. (2007) Amitriptyline is a potent blocker of human Kv1.1 and Kv7.2/7.3 channels. Anesth. Analg. 104: 1256-64, tables of contents[PMID:17456683]

528. Pusch M. (1998) Increase of the single-channel conductance of KvLQT1 potassium channels induced by the association with minK. Pflugers Arch. 437: 172-4 [PMID:9817805]

529. Qu YJ, Bondarenko VE, Xie C, Wang S, Awayda MS, Strauss HC and Morales MJ. (2007) W-7 modulates Kv4.3: pore block and Ca2+-calmodulin inhibition. Am. J. Physiol. Heart Circ. Physiol.292: H2364-77 [PMID:17220193]

530. Racapé J, Lecoq A, Romi-Lebrun R, Liu J, Kohler M, Garcia ML, Ménez A and Gasparini S. (2002) Characterization of a novel radiolabeled peptide selective for a subpopulation of voltage-gated potassium channels in mammalian brain. J. Biol. Chem. 277: 3886-93 [PMID:11707459]

531. Radicke S, Cotella D, Graf EM, Ravens U and Wettwer E. (2005) Expression and function of dipeptidylaminopeptidase-like protein 6 as a putative beta-subunit of human cardiac transient outward current encoded by Kv4.3. J. Physiol. (Lond.) 565: 751-6 [PMID:15890703]

532. Rae JL and Shepard AR. (2000) Kv3.3 potassium channels in lens epithelium and corneal endothelium. Exp. Eye Res. 70: 339-48 [PMID:10712820]

533. Rajamani S, Anderson CL, Anson BD and January CT. (2002) Pharmacological rescue of human K(+) channel long-QT2 mutations: human ether-a-go-go-related gene rescue without block. Circulation 105: 2830-5 [PMID:12070109]

534. Ramaswami M, Gautam M, Kamb A, Rudy B, Tanouye MA and Mathew MK. (1990) Human potassium channel genes: Molecular cloning and functional expression. Mol. Cell. Neurosci. 1: 214-23 [PMID:19912772]

535. Rampe D, Roy ML, Dennis A and Brown AM. (1997) A mechanism for the proarrhythmic effects of cisapride (Propulsid): high affinity blockade of the human cardiac potassium channel HERG. FEBS Lett. 417: 28-32 [PMID:9395068]

536. Rampe D, Wang Z, Fermini B, Wible B, Dage RC and Nattel S. (1995) Voltage- and time-dependent block by perhexiline of $\mathrm{K}+$ currents in human atrium and in cells expressing a Kv1.5-type cloned channel. $J$. Pharmacol. Exp. Ther. 274: 444-9 [PMID:7616429]

537. Rangaraju S, Khoo KK, Feng ZP, Crossley G, Nugent D, Khaytin I, Chi V, Pham C, Calabresi P and Pennington MW et al.. (2010) Potassium channel modulation by a toxin domain in matrix metalloprotease 23. J. Biol. Chem. 285: 9124-36 [PMID:19965868]

538. Rasband MN, Park EW, Vanderah TW, Lai J, Porreca F and Trimmer JS. (2001) Distinct potassium channels on pain-sensing neurons. Proc. Natl. Acad. Sci. U.S.A. 98: 13373-8 [PMID:11698689]

539. Rasband MN and Trimmer JS. (2001) Subunit composition and novel localization of $\mathrm{K}+$ channels in spinal cord. J. Comp. Neurol. 429: 166-76 [PMID:11086297]

540. Rasband MN, Trimmer JS, Peles E, Levinson SR and Shrager P. (1999) K+ channel distribution and clustering in developing and hypomyelinated axons of the optic nerve. J. Neurocytol. 28: 319-31 [PMID:10739574]

541. Rasband MN, Trimmer JS, Schwarz TL, Levinson SR, Ellisman MH, Schachner M and Shrager P. (1998) Potassium channel distribution, clustering, and function in remyelinating rat axons. J. Neurosci. 18: 36-47 [PMID:9412484]

542. Redman PT, He K, Hartnett KA, Jefferson BS, Hu L, Rosenberg PA, Levitan ES and Aizenman E. (2007) Apoptotic surge of potassium currents is mediated by p38 phosphorylation of Kv2.1. Proc. Natl. Acad. Sci. U.S.A. 104: 3568-73 [PMID:17360683]

543. Restano-Cassulini R, Korolkova YV, Diochot S, Gurrola G, Guasti L, Possani LD, Lazdunski M, Grishin EV, Arcangeli A and Wanke E. (2006) Species diversity and peptide toxins blocking selectivity of ether-ago-go-related gene subfamily K+ channels in the central nervous system. Mol. Pharmacol. 69: 1673-83 
[PMID:16497878]

544. Restano-Cassulini R, Olamendi-Portugal T, Zamudio F, Becerril B and Possani LD. (2008) Two novel ergtoxins, blockers of $\mathrm{K}+$-channels, purified from the Mexican scorpion Centruroides elegans elegans. Neurochem. Res. 33: 1525-33 [PMID:18338253]

545. Rettig J, Heinemann SH, Wunder F, Lorra C, Parcej DN, Dolly JO and Pongs O. (1994) Inactivation properties of voltage-gated $\mathrm{K}+$ channels altered by presence of beta-subunit. Nature 369: 289-94 [PMID:8183366]

546. Rettig J, Wunder F, Stocker M, Lichtinghagen R, Mastiaux F, Beckh S, Kues W, Pedarzani P, Schröter KH and Ruppersberg JP. (1992) Characterization of a Shaw-related potassium channel family in rat brain. EMBO J. 11: 2473-86 [PMID:1378392]

547. Rhodes KJ, Carroll KI, Sung MA, Doliveira LC, Monaghan MM, Burke SL, Strassle BW, Buchwalder L, Menegola M and Cao J et al.. (2004) KChIPs and Kv4 alpha subunits as integral components of A-type potassium channels in mammalian brain. J. Neurosci. 24: 7903-15 [PMID:15356203]

548. Rhodes KJ, Keilbaugh SA, Barrezueta NX, Lopez KL and Trimmer JS. (1995) Association and colocalization of $\mathrm{K}+$ channel alpha- and beta-subunit polypeptides in rat brain. J. Neurosci. 15: 5360-71 [PMID:7623158]

549. Rhodes KJ, Strassle BW, Monaghan MM, Bekele-Arcuri Z, Matos MF and Trimmer JS. (1997) Association and colocalization of the Kvbeta1 and Kvbeta2 beta-subunits with Kv1 alpha-subunits in mammalian brain K+ channel complexes. J. Neurosci. 17: 8246-58 [PMID:9334400]

550. Riazanski V, Becker A, Chen J, Sochivko D, Lie A, Wiestler OD, Elger CE and Beck H. (2001) Functional and molecular analysis of transient voltage-dependent $\mathrm{K}+$ currents in rat hippocampal granule cells. J. Physiol. (Lond.) 537: 391-406 [PMID:11731573]

551. Richardson FC and Kaczmarek LK. (2000) Modification of delayed rectifier potassium currents by the Kv9.1 potassium channel subunit. Hear. Res. 147: 21-30 [PMID:10962170]

552. Rivas A and Francis HW. (2005) Inner ear abnormalities in a Kcnq1 (Kvlqt1) knockout mouse: a model of Jervell and Lange-Nielsen syndrome. Otol. Neurotol. 26: 415-24 [PMID:15891643]

553. Roberds SL, Knoth KM, Po S, Blair TA, Bennett PB, Hartshorne RP, Snyders DJ and Tamkun MM. (1993) Molecular biology of the voltage-gated potassium channels of the cardiovascular system. J. Cardiovasc. Electrophysiol. 4: 68-80 [PMID:8287238]

554. Roberds SL and Tamkun MM. (1991) Cloning and tissue-specific expression of five voltage-gated potassium channel cDNAs expressed in rat heart. Proc. Natl. Acad. Sci. U.S.A. 88: 1798-802 [PMID:1705709]

555. Robertson B, Owen D, Stow J, Butler C and Newland C. (1996) Novel effects of dendrotoxin homologues on subtypes of mammalian Kv1 potassium channels expressed in Xenopus oocytes. FEBS Lett. 383: 2630 [PMID:8612784]

556. Rochat $H$, Kharrat R, Sabatier JM, Mansuelle P, Crest M, Martin-Eauclaire MF, Sampieri F, Oughideni R, Mabrouk $\mathrm{K}$ and Jacquet $\mathrm{G}$ et al.. (1998) Maurotoxin, a four disulfide bridges scorpion toxin acting on $\mathrm{K}+$ channels. Toxicon 36: 1609-11 [PMID:9792177]

557. Roe MW, Worley 3rd JF, Mittal AA, Kuznetsov A, DasGupta S, Mertz RJ, Witherspoon 3rd SM, Blair N, Lancaster ME and McIntyre MS et al.. (1996) Expression and function of pancreatic beta-cell delayed rectifier K+ channels. Role in stimulus-secretion coupling. J. Biol. Chem. 271: 32241-6 [PMID:8943282]

558. Roeper J, Lorra C and Pongs O. (1997) Frequency-dependent inactivation of mammalian A-type K+ channel KV1.4 regulated by Ca2+/calmodulin-dependent protein kinase. J. Neurosci. 17: 3379-91 [PMID:9133364]

559. Roeper J, Sewing S, Zhang Y, Sommer T, Wanner SG and Pongs O. (1998) NIP domain prevents N-type inactivation in voltage-gated potassium channels. Nature 391: 390-3 [PMID:9450755]

560. Rosati B, Marchetti P, Crociani O, Lecchi M, Lupi R, Arcangeli A, Olivotto M and Wanke E. (2000) Glucose- and arginine-induced insulin secretion by human pancreatic beta-cells: the role of HERG K(+) channels in firing and release. FASEB J. 14: 2601-10 [PMID:11099479]

561. Roti EC, Myers CD, Ayers RA, Boatman DE, Delfosse SA, Chan EK, Ackerman MJ, January CT and 
Robertson GA. (2002) Interaction with GM130 during HERG ion channel trafficking. Disruption by type 2 congenital long QT syndrome mutations. Human Ether-à-go-go-Related Gene. J. Biol. Chem. 277: 4777985 [PMID:12270925]

562. Roura-Ferrer M, Etxebarria A, Solé L, Oliveras A, Comes N, Villarroel A and Felipe A. (2009) Functional implications of KCNE subunit expression for the Kv7.5 (KCNQ5) channel. Cell. Physiol. Biochem. 24: 32534 [PMID:19910673]

563. Rudy B, Chow A, Lau D, Amarillo Y, Ozaita A, Saganich M, Moreno H, Nadal MS, Hernandez-Pineda R and Hernandez-Cruz A et al.. (1999) Contributions of Kv3 channels to neuronal excitability.Ann. N. Y. Acad. Sci. 868: 304-43 [PMID:10414303]

564. Rudy B, Sen K, Vega-Saenz de Miera E, Lau D, Ried T and Ward DC. (1991) Cloning of a human cDNA expressing a high voltage-activating, TEA-sensitive, type-A $\mathrm{K}+$ channel which maps to chromosome 1 band p21. J. Neurosci. Res. 29: 401-12 [PMID:1920536]

565. Sacco T, De Luca A and Tempia F. (2006) Properties and expression of Kv3 channels in cerebellar Purkinje cells. Mol. Cell. Neurosci. 33: 170-9 [PMID:16949837]

566. Saganich MJ, Machado E and Rudy B. (2001) Differential expression of genes encoding subthresholdoperating voltage-gated K+ channels in brain. J. Neurosci. 21: 4609-24 [PMID:11425889]

567. Saganich MJ, Vega-Saenz de Miera E, Nadal MS, Baker H, Coetzee WA and Rudy B. (1999) Cloning of components of a novel subthreshold-activating $\mathrm{K}(+)$ channel with a unique pattern of expression in the cerebral cortex. J. Neurosci. 19: 10789-802 [PMID:10594062]

568. Sahoo N, Tröger J, Heinemann SH and Schönherr R. (2010) Current inhibition of human EAG1 potassium channels by the Ca2+ binding protein S100B. FEBS Lett. 584: 3896-900 [PMID:20708613]

569. Salata JJ, Jurkiewicz NK, Wang J, Evans BE, Orme HT and Sanguinetti MC. (1998) A novel benzodiazepine that activates cardiac slow delayed rectifier K+ currents. Mol. Pharmacol. 54: 220-30 [PMID:9658209]

570. Salinas M, de Weille J, Guillemare E, Lazdunski M and Hugnot JP. (1997) Modes of regulation of shab K+ channel activity by the Kv8.1 subunit. J. Biol. Chem. 272: 8774-80 [PMID:9079713]

571. Salinas M, Duprat F, Heurteaux C, Hugnot JP and Lazdunski M. (1997) New modulatory alpha subunits for mammalian Shab K+ channels. J. Biol. Chem. 272: 24371-9 [PMID:9305895]

572. Sands SB, Lewis RS and Cahalan MD. (1989) Charybdotoxin blocks voltage-gated K+ channels in human and murine T lymphocytes. J. Gen. Physiol. 93: 1061-74 [PMID:2475579]

573. Sanguinetti MC. (2014) HERG1 channel agonists and cardiac arrhythmia. Curr Opin Pharmacol 15: 22-7 [PMID:24721650]

574. Sanguinetti MC, Curran ME, Zou A, Shen J, Spector PS, Atkinson DL and Keating MT. (1996) Coassembly of K(V)LQT1 and minK (ISK) proteins to form cardiac I(Ks) potassium channel. Nature 384: 80-3 [PMID:8900283]

575. Sanguinetti MC, Jiang C, Curran ME and Keating MT. (1995) A mechanistic link between an inherited and an acquired cardiac arrhythmia: HERG encodes the IKr potassium channel. Cell 81: 299-307 [PMID:7736582]

576. Sanguinetti MC, Johnson JH, Hammerland LG, Kelbaugh PR, Volkmann RA, Saccomano NA and Mueller AL. (1997) Heteropodatoxins: peptides isolated from spider venom that block Kv4.2 potassium channels. Mol. Pharmacol. 51: 491-8 [PMID:9058605]

577. Sanguinetti MC and Tristani-Firouzi M. (2006) hERG potassium channels and cardiac arrhythmia. Nature 440: 463-9 [PMID:16554806]

578. Sano Y, Mochizuki S, Miyake A, Kitada C, Inamura K, Yokoi H, Nozawa K, Matsushime H and Furuichi K. (2002) Molecular cloning and characterization of Kv6.3, a novel modulatory subunit for voltage-gated $\mathrm{K}(+)$ channel Kv2.1. FEBS Lett. 512: 230-4 [PMID:11852086]

579. Scheffer H, Brunt ER, Mol GJ, van der Vlies P, Stulp RP, Verlind E, Mantel G, Averyanov YN, Hofstra RM and Buys $\mathrm{CH}$. (1998) Three novel KCNA1 mutations in episodic ataxia type I families. Hum. Genet. 102: 464-6 [PMID:9600245]

580. Schenzer A, Friedrich T, Pusch M, Saftig P, Jentsch TJ, Grötzinger J and Schwake M. (2005) Molecular 
determinants of KCNQ (Kv7) K+ channel sensitivity to the anticonvulsant retigabine. J. Neurosci. 25: 505160 [PMID:15901787]

581. Schledermann W, Wulfsen I, Schwarz JR and Bauer CK. (2001) Modulation of rat erg1, erg2, erg3 and HERG K+ currents by thyrotropin-releasing hormone in anterior pituitary cells via the native signal cascade. J. Physiol. (Lond.) 532: 143-63 [PMID:11283231]

582. Schmalhofer WA, Bao J, McManus OB, Green B, Matyskiela M, Wunderler D, Bugianesi RM, Felix JP, Hanner M, Linde-Arias AR, Ponte CG, Velasco L, Koo G, Staruch MJ, Miao S, Parsons WH, Rupprecht K, Slaughter RS, Kaczorowski GJ and Garcia ML. (2002) Identification of a new class of inhibitors of the voltage-gated potassium channel, Kv1.3, with immunosuppressant properties. Biochemistry 41: 7781-94 [PMID:12056910]

583. Schmalhofer WA, Slaughter RS, Matyskiela M, Felix JP, Tang YS, Rupprecht K, Kaczorowski GJ and Garcia ML. (2003) Di-substituted cyclohexyl derivatives bind to two identical sites with positive cooperativity on the voltage-gated potassium channel, K(v)1.3. Biochemistry 42: 4733-43 [PMID:12705837]

584. Schmalz F, Kinsella J, Koh SD, Vogalis F, Schneider A, Flynn ER, Kenyon JL and Horowitz B. (1998) Molecular identification of a component of delayed rectifier current in gastrointestinal smooth muscles. $A m$. J. Physiol. 274: G901-11 [PMID:9612272]

585. Schmitz A, Sankaranarayanan A, Azam P, Schmidt-Lassen K, Homerick D, Hänsel W and Wulff H. (2005) Design of PAP-1, a selective small molecule Kv1.3 blocker, for the suppression of effector memory $T$ cells in autoimmune diseases. Mol. Pharmacol. 68: 1254-70 [PMID:16099841]

586. Scholle A, Dugarmaa S, Zimmer T, Leonhardt M, Koopmann R, Engeland B, Pongs $O$ and Benndorf K. (2004) Rate-limiting reactions determining different activation kinetics of Kv1.2 and Kv2.1 channels. J. Membr. Biol. 198: 103-12 [PMID:15138750]

587. Schopperle WM, Holmqvist MH, Zhou Y, Wang J, Wang Z, Griffith LC, Keselman I, Kusinitz F, Dagan D and Levitan IB. (1998) Slob, a novel protein that interacts with the Slowpoke calcium-dependent potassium channel. Neuron 20: 565-73 [PMID:9539129]

588. Schroeder BC, Hechenberger M, Weinreich F, Kubisch C and Jentsch TJ. (2000) KCNQ5, a novel potassium channel broadly expressed in brain, mediates M-type currents. J. Biol. Chem. 275: 24089-95 [PMID:10816588]

589. Schroeder BC, Kubisch C, Stein V and Jentsch TJ. (1998) Moderate loss of function of cyclic-AMPmodulated KCNQ2/KCNQ3 K+ channels causes epilepsy. Nature 396: 687-90 [PMID:9872318]

590. Schroeder BC, Waldegger S, Fehr S, Bleich M, Warth R, Greger R and Jentsch TJ. (2000) A constitutively open potassium channel formed by KCNQ1 and KCNE3. Nature 403: 196-9 [PMID:10646604]

591. Schröter KH, Ruppersberg JP, Wunder F, Rettig J, Stocker M and Pongs O. (1991) Cloning and functional expression of a TEA-sensitive A-type potassium channel from rat brain. FEBS Lett. 278: 211-6 [PMID:1840526]

592. Schrøder RL, Jespersen T, Christophersen P, Strøbaek D, Jensen BS and Olesen SP. (2001) KCNQ4 channel activation by BMS-204352 and retigabine. Neuropharmacology 40: 888-98 [PMID:11378159]

593. Schulte U, Thumfart JO, Klöcker N, Sailer CA, Bild W, Biniossek M, Dehn D, Deller T, Eble S and Abbass $\mathrm{K}$ et al.. (2006) The epilepsy-linked Lgi1 protein assembles into presynaptic Kv1 channels and inhibits inactivation by Kvbeta1. Neuron 49: 697-706 [PMID:16504945]

594. Schönherr R, Gessner G, Löber K and Heinemann SH. (2002) Functional distinction of human EAG1 and EAG2 potassium channels. FEBS Lett. 514: 204-8 [PMID:11943152]

595. Schönherr R and Heinemann SH. (1996) Molecular determinants for activation and inactivation of HERG, a human inward rectifier potassium channel. J. Physiol. (Lond.) 493 ( Pt 3): 635-42 [PMID:8799887]

596. Schönherr R, Löber K and Heinemann SH. (2000) Inhibition of human ether à go-go potassium channels

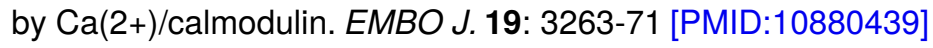

597. Schönherr R, Rosati B, HehI S, Rao VG, Arcangeli A, Olivotto M, Heinemann SH and Wanke E. (1999) Functional role of the slow activation property of ERG K+ channels. Eur. J. Neurosci. 11: 753-60 [PMID:10103069]

598. Scott VE, Rettig J, Parcej DN, Keen JN, Findlay JB, Pongs O and Dolly JO. (1994) Primary structure of a 
beta subunit of alpha-dendrotoxin-sensitive $\mathrm{K}+$ channels from bovine brain. Proc. Natl. Acad. Sci. U.S.A. 91: 1637-41 [PMID:8127858]

599. Seebohm G, Chen J, Strutz N, Culberson C, Lerche C and Sanguinetti MC. (2003) Molecular determinants of KCNQ1 channel block by a benzodiazepine. Mol. Pharmacol. 64: 70-7 [PMID:12815162]

600. Seebohm G, Lerche C, Pusch M, Steinmeyer K, Brüggemann A and Busch AE. (2001) A kinetic study on the stereospecific inhibition of KCNQ1 and I(Ks) by the chromanol 293B. Br. J. Pharmacol. 134: 1647-54 [PMID:11739240]

601. Seebohm G, Strutz-Seebohm N, Baltaev R, Korniychuk G, Knirsch M, Engel J and Lang F. (2005) Regulation of KCNQ4 potassium channel prepulse dependence and current amplitude by SGK1 in Xenopus oocytes. Cell. Physiol. Biochem. 16: 255-62 [PMID:16301825]

602. Selnick HG, Liverton NJ, Baldwin JJ, Butcher JW, Claremon DA, Elliott JM, Freidinger RM, King SA, Libby BE, McIntyre CJ, Pribush DA, Remy DC, Smith GR, Tebben AJ, Jurkiewicz NK, Lynch JJ, Salata JJ, Sanguinetti MC, SiegI PK, Slaughter DE and Vyas K. (1997) Class III antiarrhythmic activity in vivo by selective blockade of the slowly activating cardiac delayed rectifier potassium current IKs by $(R)-2-(2,4-$ trifluoromethyl)-N-[2-oxo-5-phenyl-1-(2,2,2-trifluoroethyl)- 2, 3-dihydro-1H-benzo[e][1,4]diazepin-3yl]acetamide. J. Med. Chem. 40: 3865-8 [PMID:9397166]

603. Selyanko AA, Hadley JK, Wood IC, Abogadie FC, Jentsch TJ and Brown DA. (2000) Inhibition of KCNQ14 potassium channels expressed in mammalian cells via M1 muscarinic acetylcholine receptors. J. Physiol. (Lond.) 522 Pt 3: 349-55 [PMID:10713961]

604. Serôdio P and Rudy B. (1998) Differential expression of Kv4 K+ channel subunits mediating subthreshold transient K+ (A-type) currents in rat brain. J. Neurophysiol. 79: 1081-91 [PMID:9463463]

605. Serôdio P, Vega-Saenz de Miera E and Rudy B. (1996) Cloning of a novel component of A-type K+ channels operating at subthreshold potentials with unique expression in heart and brain. J. Neurophysiol. 75: 2174-9 [PMID:8734615]

606. Sesti F and Goldstein SA. (1998) Single-channel characteristics of wild-type IKs channels and channels formed with two minK mutants that cause long QT syndrome. J. Gen. Physiol. 112: 651-63 [PMID:9834138]

607. Shah M, Mistry M, Marsh SJ, Brown DA and Delmas P. (2002) Molecular correlates of the M-current in cultured rat hippocampal neurons. J. Physiol. (Lond.) 544: 29-37 [PMID:12356878]

608. Shah MM, Migliore M, Valencia I, Cooper EC and Brown DA. (2008) Functional significance of axonal Kv7 channels in hippocampal pyramidal neurons. Proc. Natl. Acad. Sci. U.S.A. 105: 7869-74 [PMID:18515424]

609. Shahidullah M and Covarrubias M. (2003) The link between ion permeation and inactivation gating of Kv4 potassium channels. Biophys. J. 84: 928-41 [PMID:12547775]

610. Shapiro MS and DeCoursey TE. (1991) Selectivity and gating of the type L potassium channel in mouse lymphocytes. J. Gen. Physiol. 97: 1227-50 [PMID:1875188]

611. Shapiro MS and DeCoursey TE. (1991) Permeant ion effects on the gating kinetics of the type $L$ potassium channel in mouse lymphocytes. J. Gen. Physiol. 97: 1251-78 [PMID:1875189]

612. Shapiro MS, Roche JP, Kaftan EJ, Cruzblanca H, Mackie K and Hille B. (2000) Reconstitution of muscarinic modulation of the $\mathrm{KCNQ} 2 / \mathrm{KCNQ} 3 \mathrm{~K}(+)$ channels that underlie the neuronal $\mathrm{M}$ current. $\mathrm{J}$. Neurosci. 20: 1710-21 [PMID:10684873]

613. Sharma N, D'Arcangelo G, Kleinlaus A, Halegoua S and Trimmer JS. (1993) Nerve growth factor regulates the abundance and distribution of $\mathrm{K}+$ channels in PC12 cells. J. Cell Biol. 123: 1835-43 [PMID:8276901]

614. Sheng M, Liao YJ, Jan YN and Jan LY. (1993) Presynaptic A-current based on heteromultimeric K+ channels detected in vivo. Nature 365: 72-5 [PMID:8361540]

615. Sheng M, Tsaur ML, Jan YN and Jan LY. (1992) Subcellular segregation of two A-type K+ channel proteins in rat central neurons. Neuron 9: 271-84 [PMID:1497894]

616. Shepard AR and Rae JL. (1999) Electrically silent potassium channel subunits from human lens epithelium. Am. J. Physiol. 277: C412-24 [PMID:10484328]

617. Shi G, Kleinklaus AK, Marrion NV and Trimmer JS. (1994) Properties of Kv2.1 K+ channels expressed in transfected mammalian cells. J. Biol. Chem. 269: 23204-11 [PMID:8083226] 
618. Shi W, Wang HS, Pan Z, Wymore RS, Cohen IS, McKinnon D and Dixon JE. (1998) Cloning of a mammalian elk potassium channel gene and EAG mRNA distribution in rat sympathetic ganglia. J. Physiol. (Lond.) 511 ( Pt 3): 675-82 [PMID:9714851]

619. Shi W, Wymore RS, Wang HS, Pan Z, Cohen IS, McKinnon D and Dixon JE. (1997) Identification of two nervous system-specific members of the erg potassium channel gene family. J. Neurosci. 17: 9423-32 [PMID:9390998]

620. Shibata R, Misonou H, Campomanes CR, Anderson AE, Schrader LA, Doliveira LC, Carroll KI, Sweatt JD, Rhodes KJ and Trimmer JS. (2003) A fundamental role for KChIPs in determining the molecular properties and trafficking of Kv4.2 potassium channels. J. Biol. Chem. 278: 36445-54 [PMID:12829703]

621. Shumilina E, Lampert A, Lupescu A, Myssina S, Strutz-Seebohm N, Henke G, Grahammer F, Wulff P, Kuhl $D$ and Lang F. (2005) Deranged Kv channel regulation in fibroblasts from mice lacking the serum and glucocorticoid inducible kinase SGK1. J. Cell. Physiol. 204: 87-98 [PMID:15605386]

622. Silverman WR, Tang CY, Mock AF, Huh KB and Papazian DM. (2000) Mg(2+) modulates voltagedependent activation in ether-à-go-go potassium channels by binding between transmembrane segments S2 and S3. J. Gen. Physiol. 116: 663-78 [PMID:11055995]

623. Singh B, Ogiwara I, Kaneda M, Tokonami N, Mazaki E, Baba K, Matsuda K, Inoue Y and Yamakawa K. (2006) A Kv4.2 truncation mutation in a patient with temporal lobe epilepsy. Neurobiol. Dis. 24: 245-53 [PMID:16934482]

624. Singh NA, Charlier C, Stauffer D, DuPont BR, Leach RJ, Melis R, Ronen GM, Bjerre I, Quattlebaum T and Murphy JV et al.. (1998) A novel potassium channel gene, KCNQ2, is mutated in an inherited epilepsy of newborns. Nat. Genet. 18: 25-9 [PMID:9425895]

625. Singh NA, Westenskow P, Charlier C, Pappas C, Leslie J, Dillon J, Anderson VE, Sanguinetti MC and Leppert MF. (2003) KCNQ2 and KCNQ3 potassium channel genes in benign familial neonatal convulsions: expansion of the functional and mutation spectrum. Brain 126: 2726-37 [PMID:14534157]

626. Singleton DH, Boyd H, Steidl-Nichols JV, Deacon M, Groot MJ, Price D, Nettleton DO, Wallace NK, Troutman MD and Williams C et al.. (2007) Fluorescently labeled analogues of dofetilide as high-affinity fluorescence polarization ligands for the human ether-a-go-go-related gene (hERG) channel. J. Med. Chem. 50: 2931-41 [PMID:17536794]

627. Smart SL, Bosma MM and Tempel BL. (1997) Identification of the delayed rectifier potassium channel, Kv1.6, in cultured astrocytes. Glia 20: 127-34 [PMID:9179597]

628. Smart SL, Lopantsev V, Zhang CL, Robbins CA, Wang H, Chiu SY, Schwartzkroin PA, Messing A and Tempel BL. (1998) Deletion of the K(V)1.1 potassium channel causes epilepsy in mice. Neuron 20: 809-19 [PMID:9581771]

629. Smets K, Duarri A, Deconinck T, Ceulemans B, van de Warrenburg BP, Züchner S, Gonzalez MA, Schüle $\mathrm{R}$, Synofzik M and Van der Aa N et al.. (2015) First de novo KCND3 mutation causes severe Kv4.3 channel dysfunction leading to early onset cerebellar ataxia, intellectual disability, oral apraxia and epilepsy. BMC Med. Genet. 16: 51 [PMID:26189493]

630. Smith JS, Iannotti CA, Dargis P, Christian EP and Aiyar J. (2001) Differential expression of kcnq2 splice variants: implications to $\mathrm{m}$ current function during neuronal development. J. Neurosci. 21: 1096-103 [PMID:11160379]

631. Smith KE, Wilkie SE, Tebbs-Warner JT, Jarvis BJ, Gallasch L, Stocker M and Hunt DM. (2012) Functional analysis of missense mutations in Kv8.2 causing cone dystrophy with supernormal rod electroretinogram. J. Biol. Chem. 287: 43972-83 [PMID:23115240]

632. Smith PL, Baukrowitz T and Yellen G. (1996) The inward rectification mechanism of the HERG cardiac potassium channel. Nature 379: 833-6 [PMID:8587608]

633. Smith-Maxwell CJ, Ledwell JL and Aldrich RW. (1998) Role of the S4 in cooperativity of voltage-dependent potassium channel activation. J. Gen. Physiol. 111: 399-420 [PMID:9482708]

634. Snyders DJ, Tamkun MM and Bennett PB. (1993) A rapidly activating and slowly inactivating potassium channel cloned from human heart. Functional analysis after stable mammalian cell culture expression. J. Gen. Physiol. 101: 513-43 [PMID:8505626] 
635. Snyders J, Knoth KM, Roberds SL and Tamkun MM. (1992) Time-, voltage-, and state-dependent block by quinidine of a cloned human cardiac potassium channel. Mol. Pharmacol. 41: 322-30 [PMID:1538710]

636. Sobko A, Peretz A and Attali B. (1998) Constitutive activation of delayed-rectifier potassium channels by a src family tyrosine kinase in Schwann cells. EMBO J. 17: 4723-34 [PMID:9707431]

637. Sobko A, Peretz A, Shirihai O, Etkin S, Cherepanova V, Dagan D and Attali B. (1998) Heteromultimeric delayed-rectifier $\mathrm{K}+$ channels in schwann cells: developmental expression and role in cell proliferation. $J$. Neurosci. 18: 10398-408 [PMID:9852577]

638. Soldovieri MV, Boutry-Kryza N, Milh M, Doummar D, Heron B, Bourel E, Ambrosino P, Miceli F, De Maria $\mathrm{M}$ and Dorison $\mathrm{N}$ et al.. (2014) Novel KCNQ2 and KCNQ3 mutations in a large cohort of families with benign neonatal epilepsy: first evidence for an altered channel regulation by syntaxin-1A. Hum. Mutat. 35: 356-67 [PMID:24375629]

639. Soldovieri MV, Cilio MR, Miceli F, Bellini G, Miraglia del Giudice E, Castaldo P, Hernandez CC, Shapiro MS, Pascotto A, Annunziato L and Taglialatela M. (2007) Atypical gating of M-type potassium channels conferred by mutations in uncharged residues in the $\mathrm{S} 4$ region of KCNQ2 causing benign familial neonatal convulsions. J. Neurosci. 27: 4919-28 [PMID:17475800]

640. Song ZM, Hu J, Rudy B and Redman SJ. (2006) Developmental changes in the expression of calbindin and potassium-channel subunits Kv3.1b and Kv3.2 in mouse Renshaw cells. Neuroscience 139: 531-8 [PMID:16460880]

641. Speake T, Kibble JD and Brown PD. (2004) Kv1.1 and Kv1.3 channels contribute to the delayed-rectifying $\mathrm{K}+$ conductance in rat choroid plexus epithelial cells. Am. J. Physiol., Cell Physiol. 286: C611-20 [PMID:14602579]

642. Speca DJ, Ogata G, Mandikian D, Bishop HI, Wiler SW, Eum K, Wenzel HJ, Doisy ET, Matt L and Campi $\mathrm{KL}$ et al.. (2014) Deletion of the Kv2.1 delayed rectifier potassium channel leads to neuronal and behavioral hyperexcitability. Genes Brain Behav. 13: 394-408 [PMID:24494598]

643. Spitzner M, Ousingsawat J, Scheidt K, Kunzelmann K and Schreiber R. (2007) Voltage-gated K+ channels support proliferation of colonic carcinoma cells. FASEB J. 21: 35-44 [PMID:17135369]

644. Standen NB and Quayle JM. (1998) K+ channel modulation in arterial smooth muscle Acta Physiol. Scand. 164: 549-57 [PMID:9887977]

645. Stansfeld CE, Röper J, Ludwig J, Weseloh RM, Marsh SJ, Brown DA and Pongs O. (1996) Elevation of intracellular calcium by muscarinic receptor activation induces a block of voltage-activated rat ether-à-gogo channels in a stably transfected cell line. Proc. Natl. Acad. Sci. U.S.A. 93: 9910-4 [PMID:8790430]

646. Stocker $M$ and Kerschensteiner D. (1998) Cloning and tissue distribution of two new potassium channel alpha-subunits from rat brain. Biochem. Biophys. Res. Commun. 248: 927-34 [PMID:9704029]

647. Storey NM, Gómez-Angelats M, Bortner CD, Armstrong DL and Cidlowski JA. (2003) Stimulation of Kv1.3 potassium channels by death receptors during apoptosis in Jurkat T lymphocytes. J. Biol. Chem. 278: 33319-26 [PMID:12807917]

648. Stott JB, Jepps TA and Greenwood IA. (2014) K(V)7 potassium channels: a new therapeutic target in smooth muscle disorders. Drug Discov. Today 19: 413-24 [PMID:24333708]

649. Strausberg RL, Feingold EA, Grouse LH, Derge JG, Klausner RD, Collins FS, Wagner L, Shenmen CM, Schuler GD and Altschul SF et al.. (2002) Generation and initial analysis of more than 15,000 full-length human and mouse cDNA sequences. Proc. Natl. Acad. Sci. U.S.A. 99: 16899-903 [PMID:12477932]

650. Strauss KA, Markx S, Georgi B, Paul SM, Jinks RN, Hoshi T, McDonald A, First MB, Liu W and Benkert AR et al.. (2014) A population-based study of $\mathrm{KCNH} 7$ p.Arg394His and bipolar spectrum disorder.Hum. Mol. Genet. 23: 6395-406 [PMID:24986916]

651. Street VA, Robinson LC, Erford SK and Tempel BL. (1995) Molecular genetic analysis of distal mouse chromosome 6 defines gene order and positions of the deafwaddler and opisthotonos mutations.

Genomics 29: 123-30 [PMID:8530061]

652. Street VA and Tempel BL. (1997) Physical mapping of potassium channel gene clusters on mouse chromosomes three and six. Genomics 44: 110-7 [PMID:9286706]

653. Strop P, Bankovich AJ, Hansen KC, Garcia KC and Brunger AT. (2004) Structure of a human A-type 
potassium channel interacting protein DPPX, a member of the dipeptidyl aminopeptidase family. J. Mol. Biol. 343: 1055-65 [PMID:15476821]

654. Sturm P, Wimmers S, Schwarz JR and Bauer CK. (2005) Extracellular potassium effects are conserved within the rat erg K+ channel family. J. Physiol. (Lond.) 564: 329-45 [PMID:15705650]

655. Stühmer W, Ruppersberg JP, Schröter KH, Sakmann B, Stocker M, Giese KP, Perschke A, Baumann A and Pongs $O$. (1989) Molecular basis of functional diversity of voltage-gated potassium channels in mammalian brain. EMBO J. 8: 3235-44 [PMID:2555158]

656. Su CC, Li SY, Yang JJ, Su MC and Lin MJ. (2006) Studies of the effect of ionomycin on the KCNQ4 channel expressed in Xenopus oocytes. Biochem. Biophys. Res. Commun. 348: 295-300 [PMID:16876114]

657. Su J, Yu H, Lenka N, Hescheler J and Ullrich S. (2001) The expression and regulation of depolarizationactivated K+ channels in the insulin-secreting cell line INS-1. Pflugers Arch. 442: 49-56 [PMID:11374068]

658. Su K, Kyaw H, Fan P, Zeng Z, Shell BK, Carter KC and Li Y. (1997) Isolation, characterization, and mapping of two human potassium channels. Biochem. Biophys. Res. Commun. 241: 675-81 [PMID:9434767]

659. Su Z, Limberis J, Souers A, Kym P, Mikhail A, Houseman K, Diaz G, Liu X, Martin RL and Cox Blet al.. (2009) Electrophysiologic characterization of a novel hERG channel activator. Biochem. Pharmacol. 77: 1383-90 [PMID:19426677]

660. Sun Y, Quan XQ, Fromme S, Cox RH, Zhang P, Zhang L, Guo D, Guo J, Patel C and Kowey Pret al.. (2011) A novel mutation in the KCNH2 gene associated with short QT syndrome. J. Mol. Cell. Cardiol. 50: 433-41 [PMID:21130771]

661. Suzuki H, Momoi N, Ono T, Maeda S, Shikama Y, Matsuoka I, Suzuki H and Kimura J. (2005) Inhibitory effect of thiopental on ultra-rapid delayed rectifier K+ current in H9c2 cells. J. Pharmacol. Sci. 99: 177-84 [PMID:16217144]

662. Suzuki T and Takimoto K. (2004) Selective expression of HERG and Kv2 channels influences proliferation of uterine cancer cells. Int. J. Oncol. 25: 153-9 [PMID:15202000]

663. Suzuki T and Takimoto K. (2005) Differential expression of Kv4 pore-forming and KChIP auxiliary subunits in rat uterus during pregnancy. Am. J. Physiol. Endocrinol. Metab. 288: E335-41 [PMID:15454398]

664. Swanson R, Marshall J, Smith JS, Williams JB, Boyle MB, Folander K, Luneau CJ, Antanavage J, Oliva C and Buhrow SA. (1990) Cloning and expression of CDNA and genomic clones encoding three delayed rectifier potassium channels in rat brain. Neuron 4: 929-39 [PMID:2361015]

665. Swartz KJ and MacKinnon R. (1995) An inhibitor of the Kv2.1 potassium channel isolated from the venom of a Chilean tarantula. Neuron 15: 941-9 [PMID:7576642]

666. Szabò I, Gulbins E, Apfel H, Zhang X, Barth P, Busch AE, Schlottmann K, Pongs O and Lang F. (1996) Tyrosine phosphorylation-dependent suppression of a voltage-gated $\mathrm{K}+$ channel in $\mathrm{T}$ lymphocytes upon Fas stimulation. J. Biol. Chem. 271: 20465-9 [PMID:8702786]

667. Søgaard R, Ljungstrøm T, Pedersen KA, Olesen SP and Jensen BS. (2001) KCNQ4 channels expressed in mammalian cells: functional characteristics and pharmacology. Am. J. Physiol., Cell Physiol.280: C85966 [PMID:11245603]

668. Taglialatela M, Drewe JA and Brown AM. (1993) Barium blockade of a clonal potassium channel and its regulation by a critical pore residue. Mol. Pharmacol. 44: 180-90 [PMID:8341271]

669. Taglialatela M, Drewe JA, Kirsch GE, De Biasi M, Hartmann HA and Brown AM. (1993) Regulation of $\mathrm{K}+/ \mathrm{Rb}+$ selectivity and internal TEA blockade by mutations at a single site in $\mathrm{K}+$ pores. Pflugers Arch. $\mathbf{4 2 3}$ : 104-12 [PMID:7683786]

670. Takimoto K, Fomina AF, Gealy R, Trimmer JS and Levitan ES. (1993) Dexamethasone rapidly induces Kv1.5 K+ channel gene transcription and expression in clonal pituitary cells. Neuron 11: 359-69 [PMID:8352944]

671. Takimoto K, Li D, Hershman KM, Li P, Jackson EK and Levitan ES. (1997) Decreased expression of Kv4.2 and novel Kv4.3 K+ channel subunit mRNAs in ventricles of renovascular hypertensive rats. Circ. Res. 81: 533-9 [PMID:9314834] 
672. Talebizadeh Z, Kelley PM, Askew JW, Beisel KW and Smith SD. (1999) Novel mutation in the KCNQ4 gene in a large kindred with dominant progressive hearing loss. Hum. Mutat. 14: 493-501 [PMID:10571947]

673. Tamkun MM, Knoth KM, Walbridge JA, Kroemer H, Roden DM and Glover DM. (1991) Molecular cloning and characterization of two voltage-gated $\mathrm{K}+$ channel cDNAs from human ventricle. FASEB J. 5: 331-7 [PMID:2001794]

674. Tanner MR, Tajhya RB, Huq R, Gehrmann EJ, Rodarte KE, Atik MA, Norton RS, Pennington MW and Beeton C. (2017) Prolonged immunomodulation in inflammatory arthritis using the selective Kv1.3 channel blocker HsTX1[R14A] and its PEGylated analog. Clin. Immunol. 180: 45-57 [PMID:28389388]

675. Tansey EP, Chow A, Rudy B and McBain CJ. (2002) Developmental expression of potassium-channel subunit Kv3.2 within subpopulations of mouse hippocampal inhibitory interneurons. Hippocampus 12: 13748 [PMID:12000114]

676. Tatulian L, Delmas P, Abogadie FC and Brown DA. (2001) Activation of expressed KCNQ potassium currents and native neuronal M-type potassium currents by the anti-convulsant drug retigabine. $\mathrm{J}$. Neurosci. 21: 5535-45 [PMID:11466425]

677. Tempel BL, Jan YN and Jan LY. (1988) Cloning of a probable potassium channel gene from mouse brain. Nature 332: 837-9 [PMID:2451788]

678. Terlau H, Ludwig J, Steffan R, Pongs O, Stühmer W and Heinemann SH. (1996) Extracellular Mg2+ regulates activation of rat eag potassium channel. Pflugers Arch. 432: 301-12 [PMID:8662307]

679. Terrenoire C, Houslay MD, Baillie GS and Kass RS. (2009) The cardiac IKs potassium channel macromolecular complex includes the phosphodiesterase PDE4D3. J. Biol. Chem. 284: 9140-6 [PMID:19218243]

680. Teutsch C, Kondo RP, Dederko DA, Chrast J, Chien KR and Giles WR. (2007) Spatial distributions of Kv4 channels and KChip2 isoforms in the murine heart based on laser capture microdissection. Cardiovasc.

Res. 73: 739-49 [PMID:17289005]

681. Thomas D, Karle CA and Kiehn J. (2006) The cardiac $h E R G / / K r$ potassium channel as pharmacological target: structure, function, regulation, and clinical applications. Curr. Pharm. Des. 12: 2271-83 [PMID:16787254]

682. Thorneloe KS, Chen TT, Kerr PM, Grier EF, Horowitz B, Cole WC and Walsh MP. (2001) Molecular composition of 4-aminopyridine-sensitive voltage-gated $\mathrm{K}(+)$ channels of vascular smooth muscle. Circ. Res. 89: 1030-7 [PMID:11717160]

683. Thorneloe KS and Nelson MT. (2003) Properties and molecular basis of the mouse urinary bladder voltage-gated K+ current. J. Physiol. (Lond.) 549: 65-74 [PMID:12679374]

684. Tian S, Liu W, Wu Y, Rafi H, Segal AS and Desir GV. (2002) Regulation of the voltage-gated K+ channel KCNA10 by KCNA4B, a novel beta-subunit. Am. J. Physiol. Renal Physiol. 283: F142-9 [PMID:12060596]

685. Tiffany AM, Manganas LN, Kim E, Hsueh YP, Sheng M and Trimmer JS. (2000) PSD-95 and SAP97 exhibit distinct mechanisms for regulating $\mathrm{K}(+)$ channel surface expression and clustering. J. Cell Biol. 148: 147-58 [PMID:10629225]

686. Tinel N, Lauritzen I, Chouabe C, Lazdunski M and Borsotto M. (1998) The KCNQ2 potassium channel: splice variants, functional and developmental expression. Brain localization and comparison with KCNQ3. FEBS Lett. 438: 171-6 [PMID:9827540]

687. Topinka JR and Bredt DS. (1998) N-terminal palmitoylation of PSD-95 regulates association with cell membranes and interaction with K+ channel Kv1.4. Neuron 20: 125-34 [PMID:9459448]

688. Trapani JG, Andalib P, Consiglio JF and Korn SJ. (2006) Control of single channel conductance in the outer vestibule of the Kv2.1 potassium channel. J. Gen. Physiol. 128: 231-46 [PMID:16880266]

689. Trimmer JS. (1991) Immunological identification and characterization of a delayed rectifier $\mathrm{K}+$ channel polypeptide in rat brain. Proc. Natl. Acad. Sci. U.S.A. 88: 10764-8 [PMID:1961744]

690. Tristani-Firouzi M and Sanguinetti MC. (1998) Voltage-dependent inactivation of the human $\mathrm{K}+$ channel KvLQT1 is eliminated by association with minimal K+ channel (minK) subunits. J. Physiol. (Lond.) $\mathbf{5 1 0}$ ( $\mathbf{P t}$ 1): 37-45 [PMID:9625865] 
691. Trudeau MC, Titus SA, Branchaw JL, Ganetzky B and Robertson GA. (1999) Functional analysis of a mouse brain Elk-type K+ channel. J. Neurosci. 19: 2906-18 [PMID:10191308]

692. Trudeau MC, Warmke JW, Ganetzky B and Robertson GA. (1995) HERG, a human inward rectifier in the voltage-gated potassium channel family. Science 269: $92-5$ [PMID:7604285]

693. Tsantoulas C, Zhu L, Yip P, Grist J, Michael GJ and McMahon SB. (2014) Kv2 dysfunction after peripheral axotomy enhances sensory neuron responsiveness to sustained input. Exp. Neurol. 251: 115-26 [PMID:24252178]

694. Tsaur ML, Chou CC, Shih YH and Wang HL. (1997) Cloning, expression and CNS distribution of Kv4.3, an A-type K+ channel alpha subunit. FEBS Lett. 400: 215-20 [PMID:9001401]

695. Tsaur ML, Sheng M, Lowenstein DH, Jan YN and Jan LY. (1992) Differential expression of $K+$ channel mRNAs in the rat brain and down-regulation in the hippocampus following seizures. Neuron 8: 1055-67 [PMID:1610565]

696. Tschritter O, Machicao F, Stefan N, Schäfer S, Weigert C, Staiger H, Spieth C, Häring HU and Fritsche A. (2006) A new variant in the human Kv1.3 gene is associated with low insulin sensitivity and impaired glucose tolerance. J. Clin. Endocrinol. Metab. 91: 654-8 [PMID:16317062]

697. Tseng-Crank JC, Tseng GN, Schwartz A and Tanouye MA. (1990) Molecular cloning and functional expression of a potassium channel cDNA isolated from a rat cardiac library. FEBS Lett. 268: 63-8 [PMID:2384173]

698. Tzingounis AV, Heidenreich M, Kharkovets T, Spitzmaul G, Jensen HS, Nicoll RA and Jentsch TJ. (2010) The KCNQ5 potassium channel mediates a component of the afterhyperpolarization current in mouse hippocampus. Proc. Natl. Acad. Sci. U.S.A. 107: 10232-7 [PMID:20534576]

699. Uebele VN, England SK, Chaudhary A, Tamkun MM and Snyders DJ. (1996) Functional differences in Kv1.5 currents expressed in mammalian cell lines are due to the presence of endogenous Kv beta 2.1 subunits. J. Biol. Chem. 271: 2406-12 [PMID:8576199]

700. Vacher H, Diochot S, Bougis PE, Martin-Eauclaire MF and Mourre C. (2006) Kv4 channels sensitive to $\mathrm{BmTX} 3$ in rat nervous system: autoradiographic analysis of their distribution during brain ontogenesis. Eur. J. Neurosci. 24: 1325-40 [PMID:16987219]

701. Vaeth M and Feske S. (2018) Ion channelopathies of the immune system.Curr. Opin. Immunol. 52: 39-50 [PMID:29635109]

702. Valverde P, Kawai T and Taubman MA. (2004) Selective blockade of voltage-gated potassium channels reduces inflammatory bone resorption in experimental periodontal disease. J. Bone Miner. Res. 19: 155-64 [PMID:14753747]

703. Van Camp G, Coucke PJ, Akita J, Fransen E, Abe S, De Leenheer EM, Huygen PL, Cremers CW and Usami S. (2002) A mutational hot spot in the KCNQ4 gene responsible for autosomal dominant hearing impairment. Hum. Mutat. 20: 15-9 [PMID:12112653]

704. Van Hauwe P, Coucke PJ, Ensink RJ, Huygen P, Cremers CW and Van Camp G. (2000) Mutations in the $\mathrm{KCNQ} 4 \mathrm{~K}+$ channel gene, responsible for autosomal dominant hearing loss, cluster in the channel pore region. Am. J. Med. Genet. 93: 184-7 [PMID:10925378]

705. Van Wagoner DR, Pond AL, McCarthy PM, Trimmer JS and Nerbonne JM. (1997) Outward K+ current densities and Kv1.5 expression are reduced in chronic human atrial fibrillation. Circ. Res. 80: 772-81 [PMID:9168779]

706. Vandendriessche T, Kopljar I, Jenkins DP, Diego-Garcia E, Abdel-Mottaleb Y, Vermassen E, Clynen E, Schoofs L, Wulff $\mathrm{H}$ and Snyders $\mathrm{D}$ et al.. (2012) Purification, molecular cloning and functional characterization of HelaTx1 (Heterometrus laoticus): the first member of a new K-KTX subfamily. Biochem. Pharmacol. 83: 1307-17 [PMID:22305749]

707. VanDongen AM, Frech GC, Drewe JA, Joho RH and Brown AM. (1990) Alteration and restoration of K+ channel function by deletions at the $\mathrm{N}$ - and C-termini. Neuron 5: 433-43 [PMID:2206531]

708. Veeramah KR, Johnstone L, Karafet TM, Wolf D, Sprissler R, Salogiannis J, Barth-Maron A, Greenberg ME, Stuhlmann T and Weinert $S$ et al.. (2013) Exome sequencing reveals new causal mutations in children with epileptic encephalopathies. Epilepsia 54: 1270-81 [PMID:23647072] 
709. Vega-Saenz de Miera E, Moreno H, Fruhling D, Kentros C and Rudy B. (1992) Cloning of ShIII (Shaw-like) cDNAs encoding a novel high-voltage-activating, TEA-sensitive, type-A K+ channel. Proc. Biol. Sci. 248: 918 [PMID:1381835]

710. Vega-Saenz de Miera EC. (2004) Modification of Kv2.1 K+ currents by the silent Kv10 subunitsBrain Res. Mol. Brain Res. 123: 91-103 [PMID:15046870]

711. Veh RW, Lichtinghagen R, Sewing S, Wunder F, Grumbach IM and Pongs O. (1995) Immunohistochemical localization of five members of the Kv1 channel subunits: contrasting subcellular locations and neuron-specific co-localizations in rat brain. Eur. J. Neurosci. 7: 2189-205 [PMID:8563969]

712. Verma-Kurvari S, Border B and Joho RH. (1997) Regional and cellular expression patterns of four K+ channel mRNAs in the adult rat brain. Brain Res. Mol. Brain Res. 46: 54-62 [PMID:9191078]

713. Vicente R, Escalada A, Coma M, Fuster G, Sánchez-Tilló E, López-Iglesias C, Soler C, Solsona C, Celada A and Felipe A. (2003) Differential voltage-dependent $K+$ channel responses during proliferation and activation in macrophages. J. Biol. Chem. 278: 46307-20 [PMID:12923194]

714. Vicente R, Escalada A, Villalonga N, Texidó L, Roura-Ferrer M, Martín-Satué M, López-Iglesias C, Soler C, Solsona C and Tamkun MM et al.. (2006) Association of Kv1.5 and Kv1.3 contributes to the major voltagedependent K+ channel in macrophages. J. Biol. Chem. 281: 37675-85 [PMID:17038323]

715. Villarroel A and Schwarz TL. (1996) Inhibition of the Kv4 (Shal) family of transient K+ currents by arachidonic acid. J. Neurosci. 16: 2522-32 [PMID:8786428]

716. Viloria CG, Barros F, Giráldez T, Gómez-Varela D and de la Peña P. (2000) Differential effects of aminoterminal distal and proximal domains in the regulation of human erg $\mathrm{K}(+)$ channel gating. Biophys. J. 79: 231-46 [PMID:10866950]

717. Walker VE, Atanasiu R, Lam H and Shrier A. (2007) Co-chaperone FKBP38 promotes HERG trafficking.J. Biol. Chem. 282: 23509-16 [PMID:17569659]

718. Wang D and Schreurs BG. (2006) Characteristics of IA currents in adult rabbit cerebellar Purkinje cells. Brain Res. 1096: 85-96 [PMID:16716270]

719. Wang H, Kunkel DD, Martin TM, Schwartzkroin PA and Tempel BL. (1993) Heteromultimeric K+ channels in terminal and juxtaparanodal regions of neurons. Nature 365: 75-9 [PMID:8361541]

720. Wang $\mathrm{H}$, Shi $\mathrm{H}$ and Wang Z. (1999) Nicotine depresses the functions of multiple cardiac potassium channels. Life Sci. 65: PL143-9 [PMID:10503950]

721. Wang H, Shi H, Zhang L, Pourrier M, Yang B, Nattel S and Wang Z. (2000) Nicotine is a potent blocker of the cardiac A-type $\mathrm{K}(+)$ channels. Effects on cloned Kv4.3 channels and native transient outward current. Circulation 102: 1165-71 [PMID:10973847]

722. Wang HS, Brown BS, McKinnon D and Cohen IS. (2000) Molecular basis for differential sensitivity of KCNQ and I(Ks) channels to the cognitive enhancer XE991. Mol. Pharmacol. 57: 1218-23 [PMID:10825393]

723. Wang HS, Pan Z, Shi W, Brown BS, Wymore RS, Cohen IS, Dixon JE and McKinnon D. (1998) KCNQ2 and KCNQ3 potassium channel subunits: molecular correlates of the M-channel. Science 282: 1890-3 [PMID:9836639]

724. Wang J, Juhaszova M, Rubin LJ and Yuan XJ. (1997) Hypoxia inhibits gene expression of voltage-gated $\mathrm{K}+$ channel alpha subunits in pulmonary artery smooth muscle cells. J. Clin. Invest. 100: 2347-53 [PMID:9410914]

725. Wang J, Myers CD and Robertson GA. (2000) Dynamic control of deactivation gating by a soluble aminoterminal domain in HERG K(+) channels. J. Gen. Physiol. 115: 749-58 [PMID:10828248]

726. Wang J, Trudeau MC, Zappia AM and Robertson GA. (1998) Regulation of deactivation by an amino terminal domain in human ether-à-go-go-related gene potassium channels. J. Gen. Physiol. 112: 637-47 [PMID:9806971]

727. Wang J, Weigand L, Wang W, Sylvester JT and Shimoda LA. (2005) Chronic hypoxia inhibits Kv channel gene expression in rat distal pulmonary artery. Am. J. Physiol. Lung Cell Mol. Physiol. 288: L1049-58 [PMID:15665041]

728. Wang LY, Gan L, Forsythe ID and Kaczmarek LK. (1998) Contribution of the Kv3.1 potassium channel to 
high-frequency firing in mouse auditory neurones. J. Physiol. (Lond.) 509 ( Pt 1): 183-94 [PMID:9547392]

729. Wang Q, Curran ME, Splawski I, Burn TC, Millholland JM, VanRaay TJ, Shen J, Timothy KW, Vincent GM and de Jager T et al.. (1996) Positional cloning of a novel potassium channel gene: KVLQT1 mutations cause cardiac arrhythmias. Nat. Genet. 12: 17-23 [PMID:8528244]

730. Wang Z, Fermini B and Nattel S. (1993) Sustained depolarization-induced outward current in human atrial myocytes. Evidence for a novel delayed rectifier $\mathrm{K}+$ current similar to Kv1.5 cloned channel currents. Circ. Res. 73: 1061-76 [PMID:8222078]

731. Wang Z, Kiehn J, Yang Q, Brown AM and Wible BA. (1996) Comparison of binding and block produced by alternatively spliced Kvbeta1 subunits. J. Biol. Chem. 271: 28311-7 [PMID:8910452]

732. Wanke E and Restano-Cassulini R. (2007) Toxins interacting with ether-à-go-go-related gene voltagedependent potassium channels. Toxicon 49: 239-48 [PMID:17097705]

733. Waters MF, Minassian NA, Stevanin G, Figueroa KP, Bannister JP, Nolte D, Mock AF, Evidente VG, Fee DB and Müller $U$ et al.. (2006) Mutations in voltage-gated potassium channel KCNC3 cause degenerative and developmental central nervous system phenotypes. Nat. Genet. 38: 447-51 [PMID:16501573]

734. Weber C, Mello de Queiroz F, Downie BR, Suckow A, Stühmer W and Pardo LA. (2006) Silencing the activity and proliferative properties of the human Eagl Potassium Channel by RNA Interference. J. Biol. Chem. 281: 13030-7 [PMID:16537547]

735. Weerapura M, Nattel S, Chartier D, Caballero R and Hébert TE. (2002) A comparison of currents carried by HERG, with and without coexpression of MiRP1, and the native rapid delayed rectifier current. Is MiRP1 the missing link? J. Physiol. (Lond.) 540: 15-27 [PMID:11927665]

736. Weiser M, Bueno E, Sekirnjak C, Martone ME, Baker H, Hillman D, Chen S, Thornhill W, Ellisman M and Rudy B. (1995) The potassium channel subunit KV3.1b is localized to somatic and axonal membranes of specific populations of CNS neurons. J. Neurosci. 15: 4298-314 [PMID:7790912]

737. Weiser M, Vega-Saenz de Miera E, Kentros C, Moreno H, Franzen L, Hillman D, Baker H and Rudy B. (1994) Differential expression of Shaw-related K+ channels in the rat central nervous system. J. Neurosci. 14: 949-72 [PMID:8120636]

738. Wenzel HJ, Vacher H, Clark E, Trimmer JS, Lee AL, Sapolsky RM, Tempel BL and Schwartzkroin PA. (2007) Structural consequences of Kcna1 gene deletion and transfer in the mouse hippocampus. Epilepsia 48: 2023-46 [PMID:17651419]

739. Werry D, Eldstrom J, Wang Z and Fedida D. (2013) Single-channel basis for the slow activation of the repolarizing cardiac potassium current, I(Ks). Proc. Natl. Acad. Sci. U.S.A. 110: E996-1005 [PMID:23431135]

740. Wible BA, Yang Q, Kuryshev YA, Accili EA and Brown AM. (1998) Cloning and expression of a novel K+ channel regulatory protein, KChAP. J. Biol. Chem. 273: 11745-51 [PMID:9565597]

741. Wickenden AD, Jegla TJ, Kaprielian R and Backx PH. (1999) Regional contributions of Kv1.4, Kv4.2, and Kv4.3 to transient outward K+ current in rat ventricle. Am. J. Physiol. 276: H1599-607 [PMID:10330244]

742. Wickenden AD, Roeloffs R, McNaughton-Smith G and Rigdon GC. (2004) KCNQ potassium channels: drug targets for the treatment of epilepsy and pain. Expert Opin Ther Pat 14: 1-13

743. Wickenden AD, Yu W, Zou A, Jegla T and Wagoner PK. (2000) Retigabine, a novel anti-convulsant, enhances activation of KCNQ2/Q3 potassium channels. Mol. Pharmacol. 58: 591-600 [PMID:10953053]

744. Wickenden AD, Zou A, Wagoner PK and Jegla T. (2001) Characterization of KCNQ5/Q3 potassium channels expressed in mammalian cells. Br. J. Pharmacol. 132: 381-4 [PMID:11159685]

745. Wimmers S, Bauer CK and Schwarz JR. (2002) Biophysical properties of heteromultimeric erg K+ channels. Pflugers Arch. 445: 423-30 [PMID:12466946]

746. Wisniewska MB, Nagalski A, Dabrowski M, Misztal K and Kuznicki J. (2012) Novel $\beta$-catenin target genes identified in thalamic neurons encode modulators of neuronal excitability. BMC Genomics 13: 635 [PMID:23157480]

747. Wissinger B, Dangel S, Jägle H, Hansen L, Baumann B, Rudolph G, Wolf C, Bonin M, Koeppen K and Ladewig T et al.. (2008) Cone dystrophy with supernormal rod response is strictly associated with mutations in KCNV2. Invest. Ophthalmol. Vis. Sci. 49: 751-7 [PMID:18235024] 
748. Wissinger B, Schaich S, Baumann B, Bonin M, Jägle H, Friedburg C, Varsányi B, Hoyng CB, Dollfus H and Heckenlively JR et al.. (2011) Large deletions of the KCNV2 gene are common in patients with cone dystrophy with supernormal rod response. Hum. Mutat. 32: 1398-406 [PMID:21882291]

749. Wolf-Goldberg T, Michaelevski I, Sheu L, Gaisano HY, Chikvashvili D and Lotan I. (2006) Target soluble $\mathrm{N}$-ethylmaleimide-sensitive factor attachment protein receptors (t-SNAREs) differently regulate activation and inactivation gating of Kv2.2 and Kv2.1: Implications on pancreatic islet cell Kv channels. Mol. Pharmacol. 70: 818-28 [PMID:16754785]

750. Wollnik B, Schroeder BC, Kubisch C, Esperer HD, Wieacker P and Jentsch TJ. (1997) Pathophysiological mechanisms of dominant and recessive KVLQT1 K+ channel mutations found in inherited cardiac arrhythmias. Hum. Mol. Genet. 6: 1943-9 [PMID:9302275]

751. Wu C, Hayama E, Imamura S, Matsuoka R and Nakanishi T. (2007) Developmental changes in the expression of voltage-gated potassium channels in the ductus arteriosus of the fetal rat. Heart Vessels 22: 34-40 [PMID:17285444]

752. Wu DM, Jiang M, Zhang M, Liu XS, Korolkova YV and Tseng GN. (2006) KCNE2 is colocalized with KCNQ1 and KCNE1 in cardiac myocytes and may function as a negative modulator of $\mathrm{I}(\mathrm{Ks})$ current amplitude in the heart. Heart rhythm : the official journal of the Heart Rhythm Society3: 1469-80 [PMID:17161791]

753. Wu H, Cowing JA, Michaelides M, Wilkie SE, Jeffery G, Jenkins SA, Mester V, Bird AC, Robson AG, Holder GE, Moore AT, Hunt DM and Webster AR. (2006) Mutations in the gene KCNV2 encoding a voltage-gated potassium channel subunit cause "cone dystrophy with supernormal rod electroretinogram" in humans. Am. J. Hum. Genet. 79: 574-9 [PMID:16909397]

754. Wu YJ, Boissard CG, Greco C, Gribkoff VK, Harden DG, He H, L'Heureux A, Kang SH, Kinney GG, Knox RJ, Natale J, Newton AE, Lehtinen-Oboma S, Sinz MW, Sivarao DV, Starrett JE, Sun LQ, Tertyshnikova S, Thompson MW, Weaver D, Wong HS, Zhang L and Dworetzky SI. (2003) (S)-N-[1-(3-morpholin-4ylphenyl)ethyl]- 3-phenylacrylamide: an orally bioavailable KCNQ2 opener with significant activity in a cortical spreading depression model of migraine. J. Med. Chem. 46: 3197-200 [PMID:12852750]

755. Wua YJ and Dworetzky SI. (2005) Recent developments on KCNQ potassium channel openers. Curr. Med. Chem. 12: 453-60 [PMID:15720253]

756. Wulff H, Calabresi PA, Allie R, Yun S, Pennington M, Beeton C and Chandy KG. (2003) The voltage-gated

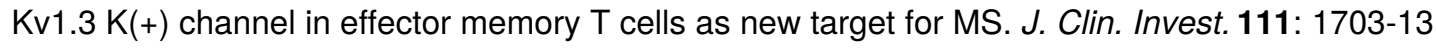
[PMID:12782673]

757. Wulff $H$, Knaus HG, Pennington M and Chandy KG. (2004) K+ channel expression during B cell differentiation: implications for immunomodulation and autoimmunity. J. Immunol. 173: 776-86 [PMID:15240664]

758. Wulfsen I, Hauber HP, Schiemann D, Bauer CK and Schwarz JR. (2000) Expression of mRNA for voltagedependent and inward-rectifying $\mathrm{K}$ channels in GH3/B6 cells and rat pituitary. J. Neuroendocrinol. 12: 26372 [PMID:10718922]

759. Wymore RS, Gintant GA, Wymore RT, Dixon JE, McKinnon D and Cohen IS. (1997) Tissue and species distribution of mRNA for the IKr-like K+ channel, erg. Circ. Res. 80: 261-8 [PMID:9012748]

760. Wymore RS, Korenberg JR, Kinoshita KD, Aiyar J, Coyne C, Chen XN, Hustad CM, Copeland NG, Gutman GA and Jenkins NA et al.. (1994) Genomic organization, nucleotide sequence, biophysical properties, and localization of the voltage-gated $\mathrm{K}+$ channel gene $\mathrm{KCNA} 4 / \mathrm{Kv} 1.4$ to mouse chromosome 2/human 11p14 and mapping of KCNC1/Kv3.1 to mouse 7/human 11p14.3-p15.2 and KCNA1/Kv1.1 to human 12p13. Genomics 20: 191-202 [PMID:8020965]

761. Xie C, Su H, Guo T, Yan Y, Peng X, Cao R, Wang Y, Chen P, Wang X and Liang S. (2014) Synaptotagmin I delays the fast inactivation of Kv1.4 channel through interaction with its $\mathrm{N}$-terminus. $\mathrm{Mol}$ Brain 7: 4 [PMID:24423395]

762. Xie G, Harrison J, Clapcote SJ, Huang Y, Zhang JY, Wang LY and Roder JC. (2010) A new Kv1.2 channelopathy underlying cerebellar ataxia. J. Biol. Chem. 285: 32160-73 [PMID:20696761]

763. Xiong Q, Sun H and Li M. (2007) Zinc pyrithione-mediated activation of voltage-gated KCNQ potassium 
channels rescues epileptogenic mutants. Nat. Chem. Biol. 3: 287-96 [PMID:17435769]

764. Xu C, Lu Y, Tang G and Wang R. (1999) Expression of voltage-dependent K(+) channel genes in mesenteric artery smooth muscle cells. Am. J. Physiol. 277: G1055-63 [PMID:10564112]

765. Xu H, Dixon JE, Barry DM, Trimmer JS, Merlie JP, McKinnon D and Nerbonne JM. (1996) Developmental analysis reveals mismatches in the expression of $\mathrm{K}+$ channel alpha subunits and voltage-gated $\mathrm{K}+$ channel currents in rat ventricular myocytes. J. Gen. Physiol. 108: 405-19 [PMID:8923266]

766. Xu J, Wang P, Li Y, Li G, Kaczmarek LK, Wu Y, Koni PA, Flavell RA and Desir GV. (2004) The voltagegated potassium channel Kv1.3 regulates peripheral insulin sensitivity. Proc. Natl. Acad. Sci. U.S.A.101: 3112-7 [PMID:14981264]

767. Xu M, Cao R, Xiao R, Zhu MX and Gu C. (2007) The axon-dendrite targeting of Kv3 (Shaw) channels is determined by a targeting motif that associates with the T1 domain and ankyrin G. J. Neurosci. 27: 1415870 [PMID:18094255]

768. Xu Q, Chang A, Tolia A and Minor Jr DL. (2013) Structure of a Ca(2+)/CaM:Kv7.4 (KCNQ4) B-helix complex provides insight into M current modulation. J. Mol. Biol. 425: 378-94 [PMID:23178170]

769. Yamagishi T, Ishii K and Taira N. (1995) Antiarrhythmic and bradycardic drugs inhibit currents of cloned K+ channels, KV1.2 and KV1.4. Eur. J. Pharmacol. 281: 151-9 [PMID:7589202]

770. Yan L, Figueroa DJ, Austin CP, Liu Y, Bugianesi RM, Slaughter RS, Kaczorowski GJ and Kohler MG. (2004) Expression of voltage-gated potassium channels in human and rhesus pancreatic islets. Diabetes 53: 597-607 [PMID:14988243]

771. Yan L, Herrington J, Goldberg E, Dulski PM, Bugianesi RM, Slaughter RS, Banerjee P, Brochu RM, Priest BT and Kaczorowski GJ et al.. (2005) Stichodactyla helianthus peptide, a pharmacological tool for studying Kv3.2 channels. Mol. Pharmacol. 67: 1513-21 [PMID:15709110]

772. Yang T, Kupershmidt S and Roden DM. (1995) Anti-minK antisense decreases the amplitude of the rapidly activating cardiac delayed rectifier K+ current. Circ. Res. 77: 1246-53 [PMID:7586238]

773. Yang T, Yang P, Roden DM and Darbar D. (2010) Novel KCNA5 mutation implicates tyrosine kinase signaling in human atrial fibrillation. Heart Rhythm 7: 1246-52 [PMID:20638934]

774. Yang WP, Levesque PC, Little WA, Conder ML, Ramakrishnan P, Neubauer MG and Blanar MA. (1998) Functional expression of two KvLQT1-related potassium channels responsible for an inherited idiopathic epilepsy. J. Biol. Chem. 273: 19419-23 [PMID:9677360]

775. Yang Y, Li J, Lin X, Yang Y, Hong K, Wang L, Liu J, Li L, Yan D and Liang Dt al.. (2009) Novel KCNA5 loss-of-function mutations responsible for atrial fibrillation. J. Hum. Genet. 54: 277-83 [PMID:19343045]

776. Yang Y and Sigworth FJ. (1998) Single-channel properties of IKs potassium channels.J. Gen. Physiol. 112: 665-78 [PMID:9834139]

777. Yang Y, Vasylyev DV, Dib-Hajj F, Veeramah KR, Hammer MF, Dib-Hajj SD and Waxman SG. (2013) Multistate structural modeling and voltage-clamp analysis of epilepsy/autism mutation Kv10.2-R327H demonstrate the role of this residue in stabilizing the channel closed state. J. Neurosci. 33: 16586-93 [PMID:24133262]

778. Yao X, Liu Y, Tung F and Desir GV. (1996) Genomic structure and regulation of Kcn1, a cGMP-gated potassium channel. Am. J. Physiol. 271: F37-41 [PMID:8760241]

779. Yao X, Segal AS, Welling P, Zhang X, McNicholas CM, Engel D, Boulpaep EL and Desir GV. (1995) Primary structure and functional expression of a cGMP-gated potassium channel. Proc. Natl. Acad. Sci. U.S.A. 92: 11711-5 [PMID:8524834]

780. Yao X, Tian S, Chan HY, Biemesderfer D and Desir GV. (2002) Expression of KCNA10, a voltage-gated K channel, in glomerular endothelium and at the apical membrane of the renal proximal tubule. J. Am. Soc. Nephrol. 13: 2831-9 [PMID:12444201]

781. Ye H, Ma WL, Yang ML, Liu SY and Wang DX. (2004) Effect of chronic cigarette smoking on largeconductance calcium-activated potassium channel and Kv1.5 expression in bronchial smooth muscle cells of rats. Sheng li xue bao : [Acta physiologica Sinica]56: 573-8 [PMID:15497036]

782. Yeung SY, Ohya S, Sergeant GP, Pucovský V and Greenwood IA. (2006) Pharmacological and molecular evidence for the involvement of Kv4.3 in ultra-fast activating K+ currents in murine portal vein myocytes. 
Br. J. Pharmacol. 149: 676-86 [PMID:17016508]

783. Yeung SY, Thompson D, Wang Z, Fedida D and Robertson B. (2005) Modulation of Kv3 subfamily potassium currents by the sea anemone toxin BDS: significance for CNS and biophysical studies. $J$. Neurosci. 25: 8735-45 [PMID:16177043]

784. Yokoyama S, Imoto K, Kawamura T, Higashida H, Iwabe N, Miyata T and Numa S. (1989) Potassium channels from NG108-15 neuroblastoma-glioma hybrid cells. Primary structure and functional expression from cDNAs. FEBS Lett. 259: 37-42 [PMID:2599109]

785. You T, Mao W, Cai B, Li F and Xu H. (2015) Two novel Brugada syndrome-associated mutations increase KV4.3 membrane expression and function. Int. J. Mol. Med. 36: 309-15 [PMID:26016905]

786. Ypey DL and Clapham DE. (1984) Development of a delayed outward-rectifying $\mathrm{K}+$ conductance in cultured mouse peritoneal macrophages. Proc. Natl. Acad. Sci. U.S.A. 81: 3083-7 [PMID:6328495]

787. Yu H, Wu M, Townsend SD, Zou B, Long S, Daniels JS, McManus OB, Li M, Lindsley CW and Hopkins CR. (2011) Discovery, Synthesis, and Structure Activity Relationship of a Series of N-Arylbicyclo[2.2.1] heptane-2-carboxamides: Characterization of ML213 as a Novel KCNQ2 and KCNQ4 Potassium Channel Opener. ACS Chem Neurosci 2: 572-577 [PMID:22125664]

788. Yu SP, Yeh CH, Sensi SL, Gwag BJ, Canzoniero LM, Farhangrazi ZS, Ying HS, Tian M, Dugan LL and Choi DW. (1997) Mediation of neuronal apoptosis by enhancement of outward potassium current. Science 278: 114-7 [PMID:9311914]

789. Yuan LL, Chen X, Kunjilwar K, Pfaffinger P and Johnston D. (2006) Acceleration of $K+$ channel inactivation by MEK inhibitor U0126. Am. J. Physiol., Cell Physiol. 290: C165-71 [PMID:16135544]

790. Yuan XJ, Wang J, Juhaszova M, Golovina VA and Rubin LJ. (1998) Molecular basis and function of voltage-gated $\mathrm{K}+$ channels in pulmonary arterial smooth muscle cells. Am. J. Physiol. 274: L621-35 [PMID:9575881]

791. Yue $\mathrm{C}$ and Yaari Y. (2004) KCNQ/M channels control spike afterdepolarization and burst generation in hippocampal neurons. J. Neurosci. 24: 4614-24 [PMID:15140933]

792. Zadeh AD, Cheng Y, Xu H, Wong N, Wang Z, Goonasekara C, Steele DF and Fedida D. (2009) Kif5b is an essential forward trafficking motor for the Kv1.5 cardiac potassium channel. J. Physiol. (Lond.) 587: 456574 [PMID:19675065]

793. Zagha E, Lang EJ and Rudy B. (2008) Kv3.3 channels at the Purkinje cell soma are necessary for generation of the classical complex spike waveform. J. Neurosci. 28: 1291-300 [PMID:18256249]

794. Zagha E, Manita S, Ross WN and Rudy B. (2010) Dendritic Kv3.3 potassium channels in cerebellar purkinje cells regulate generation and spatial dynamics of dendritic Ca2+ spikes. J. Neurophysiol. 103: 3516-25 [PMID:20357073]

795. Zagha E, Ozaita A, Chang SY, Nadal MS, Lin U, Saganich MJ, McCormack T, Akinsanya KO, Qi SY and Rudy B. (2005) DPP10 modulates Kv4-mediated A-type potassium channels. J. Biol. Chem. 280: 18853-61 [PMID:15671030]

796. Zaks-Makhina E, Kim Y, Aizenman E and Levitan ES. (2004) Novel neuroprotective K+ channel inhibitor identified by high-throughput screening in yeast. Mol. Pharmacol. 65: 214-9 [PMID:14722253]

797. Zeng H, Lozinskaya IM, Lin Z, Willette RN, Brooks DP and Xu X. (2006) Mallotoxin is a novel human ethera-go-go-related gene (hERG) potassium channel activator. J. Pharmacol. Exp. Ther. 319: 957-62 [PMID:16928897]

798. Zerr P, Adelman JP and Maylie J. (1998) Episodic ataxia mutations in Kv1.1 alter potassium channel function by dominant negative effects or haploinsufficiency. J. Neurosci. 18: 2842-8 [PMID:9526001]

799. Zhang CL, Messing A and Chiu SY. (1999) Specific alteration of spontaneous GABAergic inhibition in cerebellar purkinje cells in mice lacking the potassium channel Kv1. 1. J. Neurosci. 19: 2852-64 [PMID:10191303]

800. Zhang F, Mi Y, Qi JL, Li JW, Si M, Guan BC, Du XN, An HL and Zhang HL. (2013) Modulation of K(v)7 potassium channels by a novel opener pyrazolo[1,5-a]pyrimidin-7(4H)-one compound QO-58. Br. J. Pharmacol. 168: 1030-42 [PMID:23013484]

801. Zhang M, Liu XS, Diochot S, Lazdunski M and Tseng GN. (2007) APETx1 from sea anemone Anthopleura 
elegantissima is a gating modifier peptide toxin of the human ether-a-go-go- related potassium channel. Mol. Pharmacol. 72: 259-68 [PMID:17473056]

802. Zhang X, Bertaso F, Yoo JW, Baumgärtel K, Clancy SM, Lee V, Cienfuegos C, Wilmot C, Avis J and Hunyh T et al.. (2010) Deletion of the potassium channel Kv12.2 causes hippocampal hyperexcitability and epilepsy. Nat. Neurosci. 13: 1056-8 [PMID:20676103]

803. Zhang X, Bursulaya B, Lee CC, Chen B, Pivaroff $K$ and Jegla T. (2009) Divalent cations slow activation of EAG family K+ channels through direct binding to S4. Biophys. J. 97: 110-20 [PMID:19580749]

804. Zhong CB, Pan YP, Tong XY, Xu XH and Wang XL. (2005) Delayed rectifier potassium currents and Kv2.1 mRNA increase in hippocampal neurons of scopolamine-induced memory-deficient rats. Neurosci. Lett. 373: 99-104 [PMID:15567561]

805. Zhou J, Augelli-Szafran CE, Bradley JA, Chen X, Koci BJ, Volberg WA, Sun Z and Cordes JS. (2005) Novel potent human ether-a-go-go-related gene (hERG) potassium channel enhancers and their in vitro antiarrhythmic activity. Mol. Pharmacol. 68: 876-84 [PMID:15976038]

806. Zhou L, Messing A and Chiu SY. (1999) Determinants of excitability at transition zones in Kv1.1-deficient myelinated nerves. J. Neurosci. 19: 5768-81 [PMID:10407018]

807. Zhou Z, Gong Q, Ye B, Fan Z, Makielski JC, Robertson GA and January CT. (1998) Properties of HERG channels stably expressed in HEK 293 cells studied at physiological temperature. Biophys. J. 74: 230-41 [PMID:9449325]

808. Zhou Z, Vorperian VR, Gong Q, Zhang S and January CT. (1999) Block of HERG potassium channels by the antihistamine astemizole and its metabolites desmethylastemizole and norastemizole. J. Cardiovasc. Electrophysiol. 10: 836-43 [PMID:10376921]

809. Zhu XR, Netzer R, Böhlke K, Liu Q and Pongs O. (1999) Structural and functional characterization of Kv6.2 a new gamma-subunit of voltage-gated potassium channel. Recept. Channels 6: 337-50 [PMID:10551266]

810. Zhu XR, Wulf A, Schwarz M, Isbrandt D and Pongs O. (1999) Characterization of human Kv4.2 mediating a rapidly-inactivating transient voltage-sensitive $\mathrm{K}+$ current. Recept. Channels 6: 387-400 [PMID:10551270]

811. Ziechner U, Schönherr R, Born AK, Gavrilova-Ruch O, Glaser RW, Malesevic M, Küllertz G and Heinemann SH. (2006) Inhibition of human ether à go-go potassium channels by $\mathrm{Ca2+/calmodulin} \mathrm{binding}$ to the cytosolic $\mathrm{N}$ - and C-termini. FEBS J. 273: 1074-86 [PMID:16478480]

812. Zou A, Lin Z, Humble M, Creech CD, Wagoner PK, Krafte D, Jegla TJ and Wickenden AD. (2003) Distribution and functional properties of human KCNH8 (Elk1) potassium channels. Am. J. Physiol., Cell Physiol. 285: C1356-66 [PMID:12890647]

813. Zuberi SM, Eunson LH, Spauschus A, De Silva R, Tolmie J, Wood NW, McWilliam RC, Stephenson JB, Stephenson JP and Kullmann DM et al.. (1999) A novel mutation in the human voltage-gated potassium channel gene (Kv1.1) associates with episodic ataxia type 1 and sometimes with partial epilepsy. Brain 122 ( Pt 5): 817-25 [PMID:10355668] 